70

\title{
WATER LEVELS IN THE YUCCA MOUNTAIN AREA, NEVADA, 1995
}

\section{USGS/OFR--97-101}

U.S. GEOLOGICAL SURVEY

Open-File Report 97-101

\author{
RECEIVED \\ MAY 111998 \\ OSTI
}

Prepared in cooperation with the

NEVADA OPERATIONS OFFICE,

U.S. DEPARTMENT OF ENERGY, under

Interagency Agreement DE-AI08-92NV10874

DIC QUAIITY INOPECTED 1

DISTRTBOTION STATEMIEV 4 


\section{DISCLAIMER}

This repor was prepared as an account of work sponsored by an agency of the United States Government. Neither the United States Government oor any agency thereof, nor any of their employees, makes any warranty, express or implied, or assumes any legal liability or responsibility for the accuracy, completeness, or usefulness of any information, apparatus, product, or process disclosed, or represents that its use would not iniringe privately owned rights. Reference herein to any specific commercial product, process, or service by trade name, trademark, manufacturer, or otherwise does not necessarily constitute or imply its endorsement, recommendation, or favoring by the United States Government or any agency thereof. The views and opinions of authors expressed herein do not necessarily state or reflect those of the United States Government or any agency thereof. 


\section{Water Levels in the Yucca Mountain Area, Nevada, 1995}

by Robert P. Graves and Robert L. Goemaat

U.S. GEOLOGICAL SURVEY

$$
\text { USGS/OFR--97-10/ }
$$

Open-File Report 97-101

Prepared in cooperation with the

NEVADA OPERATIONS OFFICE,

U.S. DEPARTMENT OF ENERGY, under

Interagency Agreement DE-Al08-92NV10874

DISTRIBUTION OF THIS DOCUMENT IS UNLIMITEO

Denver, Colorado

1998 


\title{
U.S. DEPARTMENT OF THE INTERIOR \\ BRUCE BABBITT, Secretary
}

\author{
U.S. GEOLOGICAL SURVEY
}

Thomas J. Casadevall, Acting Director

The use of firm, trade, and brand names in this report is for identification purposes only and does not constitute endorsement by the U.S. Geological Survey.

For additional information write to:

Chief, Earth Science Investigations Program

Yucca Mountain Project Branch

U.S. Geological Survey

Box 25046, Mail Stop 421

Denver Federal Center

Denver, CO 80225-0046
Copies of this report can be purchased from:

U.S. Geological Survey

Information Services

Box 25286

Federal Center

Denver, CO 80225 


\section{CONTENTS}

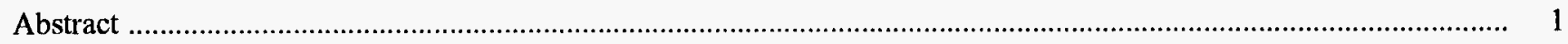

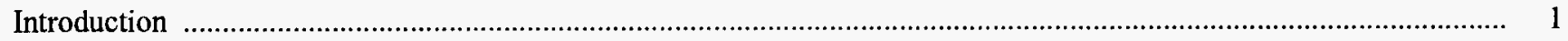

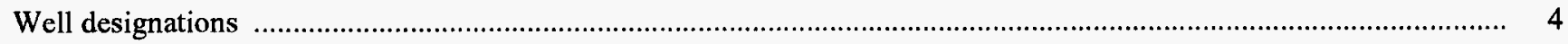

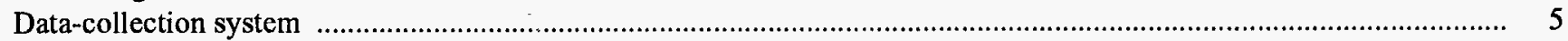

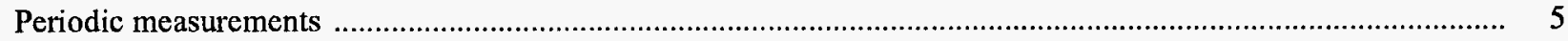

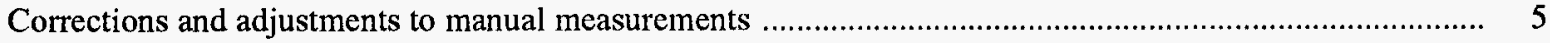

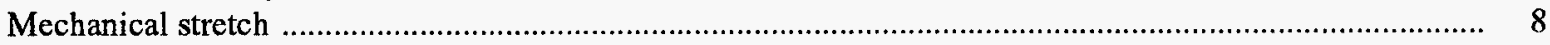

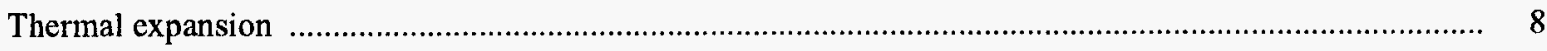

Multiconductor-cable correction .............................................................................................. 9

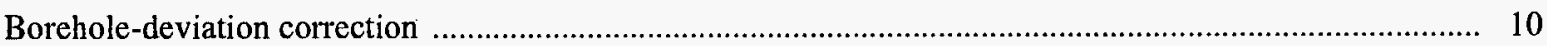

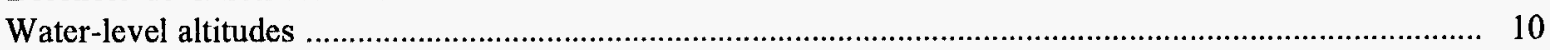

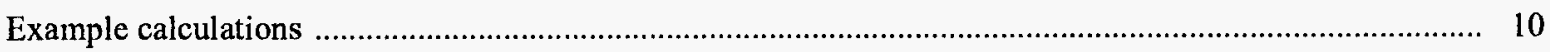

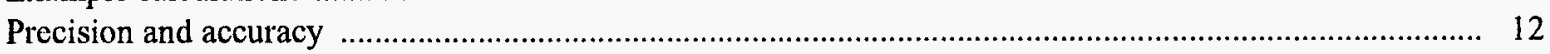

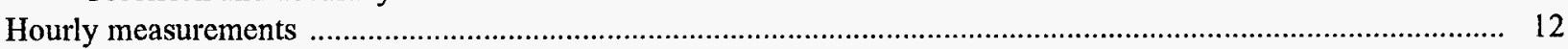

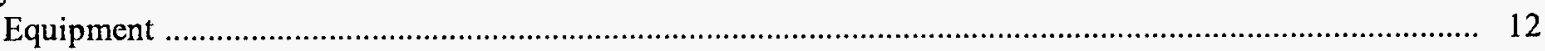

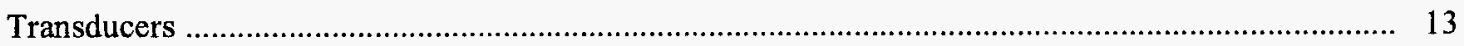

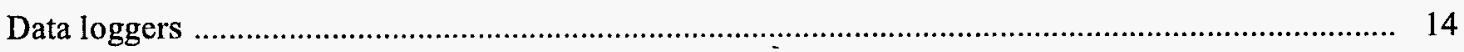

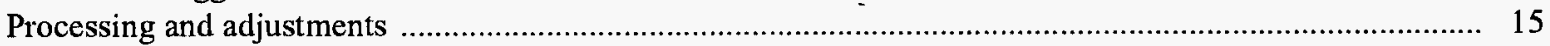

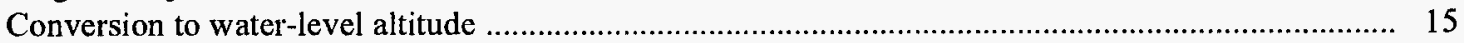

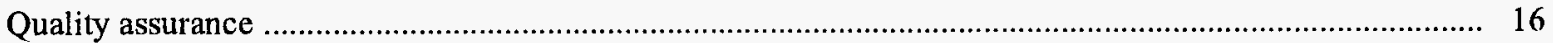

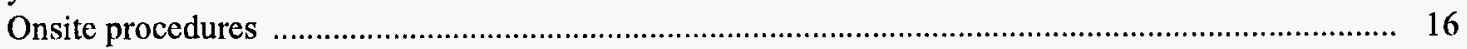

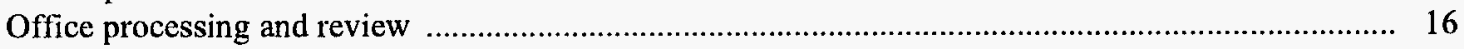

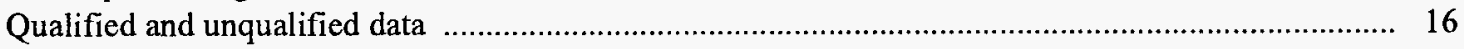

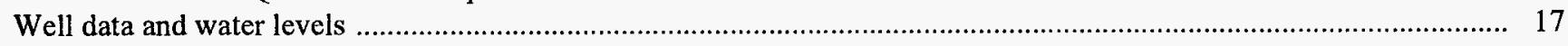

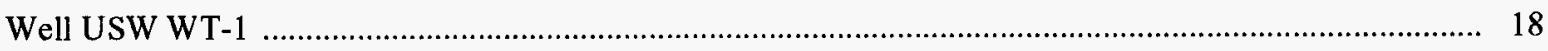

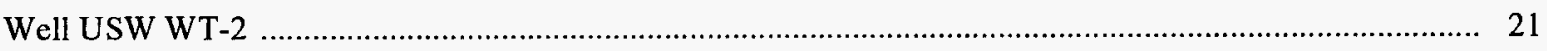

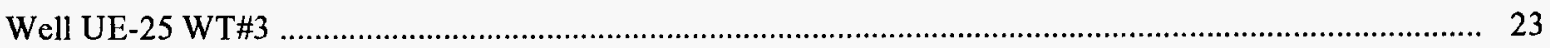

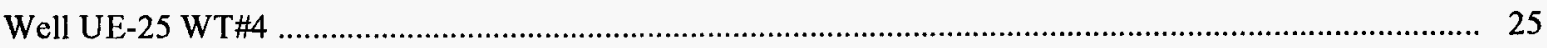

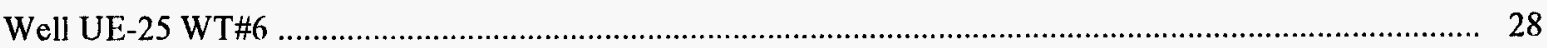

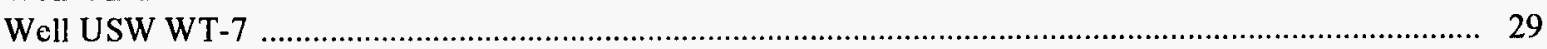

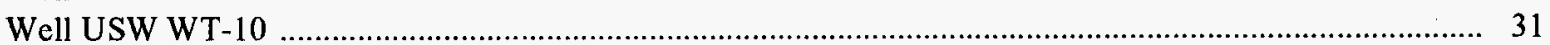

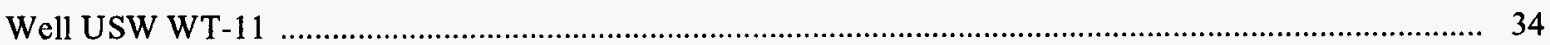

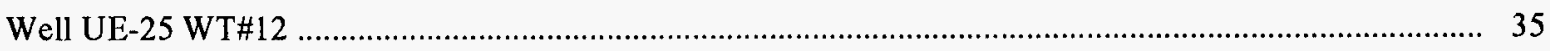

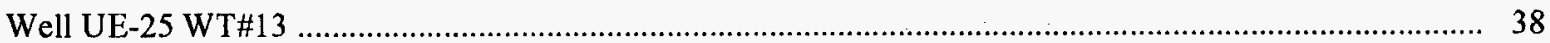

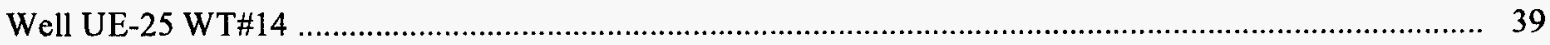

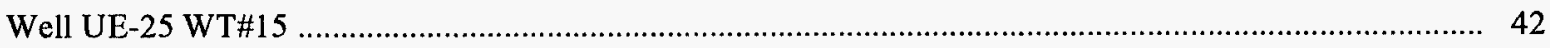

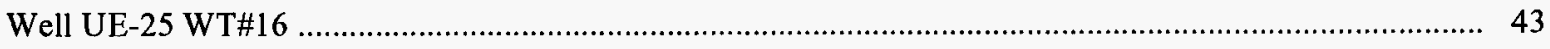

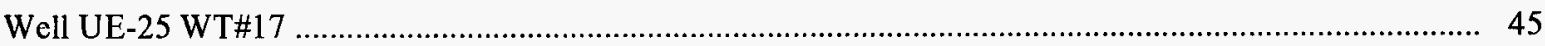

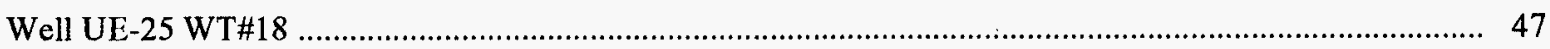

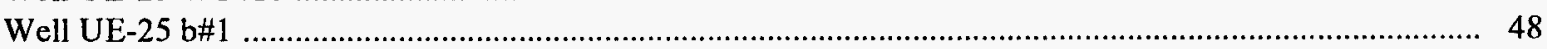

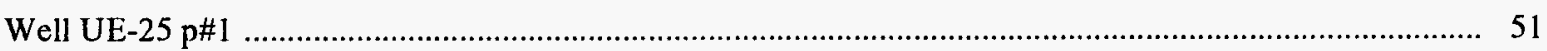

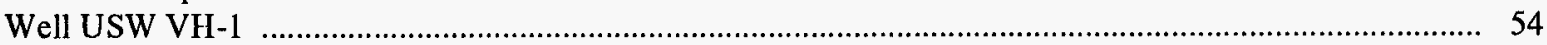

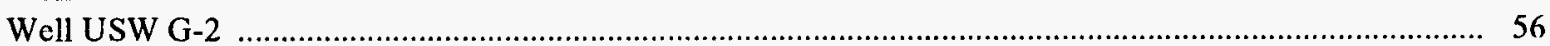

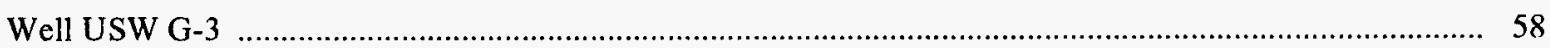

Well USW H-1

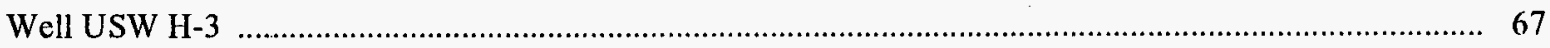

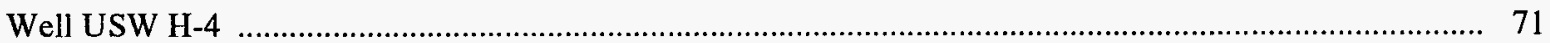

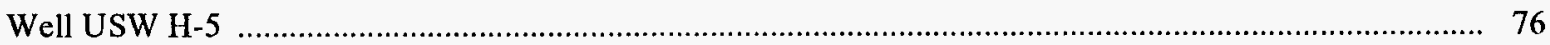

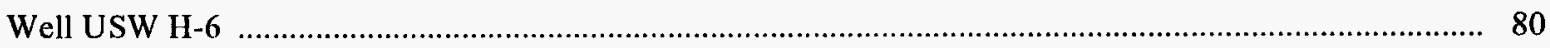

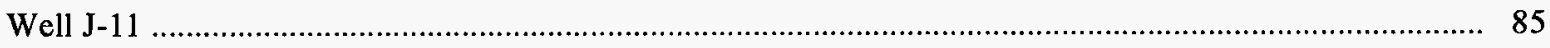

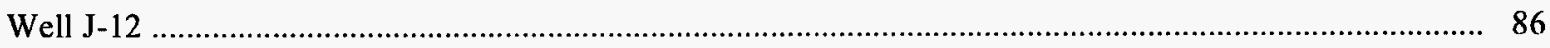

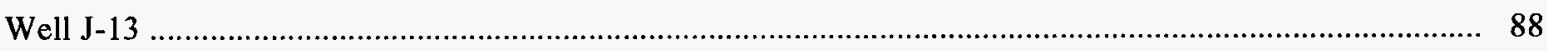

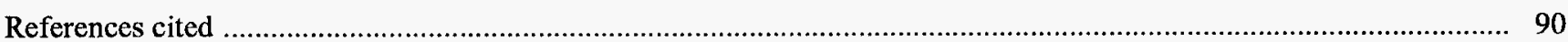




\section{FIGURES}

1. Map showing location of Yucca Mountain area and location of wells ........................................................ 2

2-37. Hydrographs showing water-level altitudes, 1995, for:

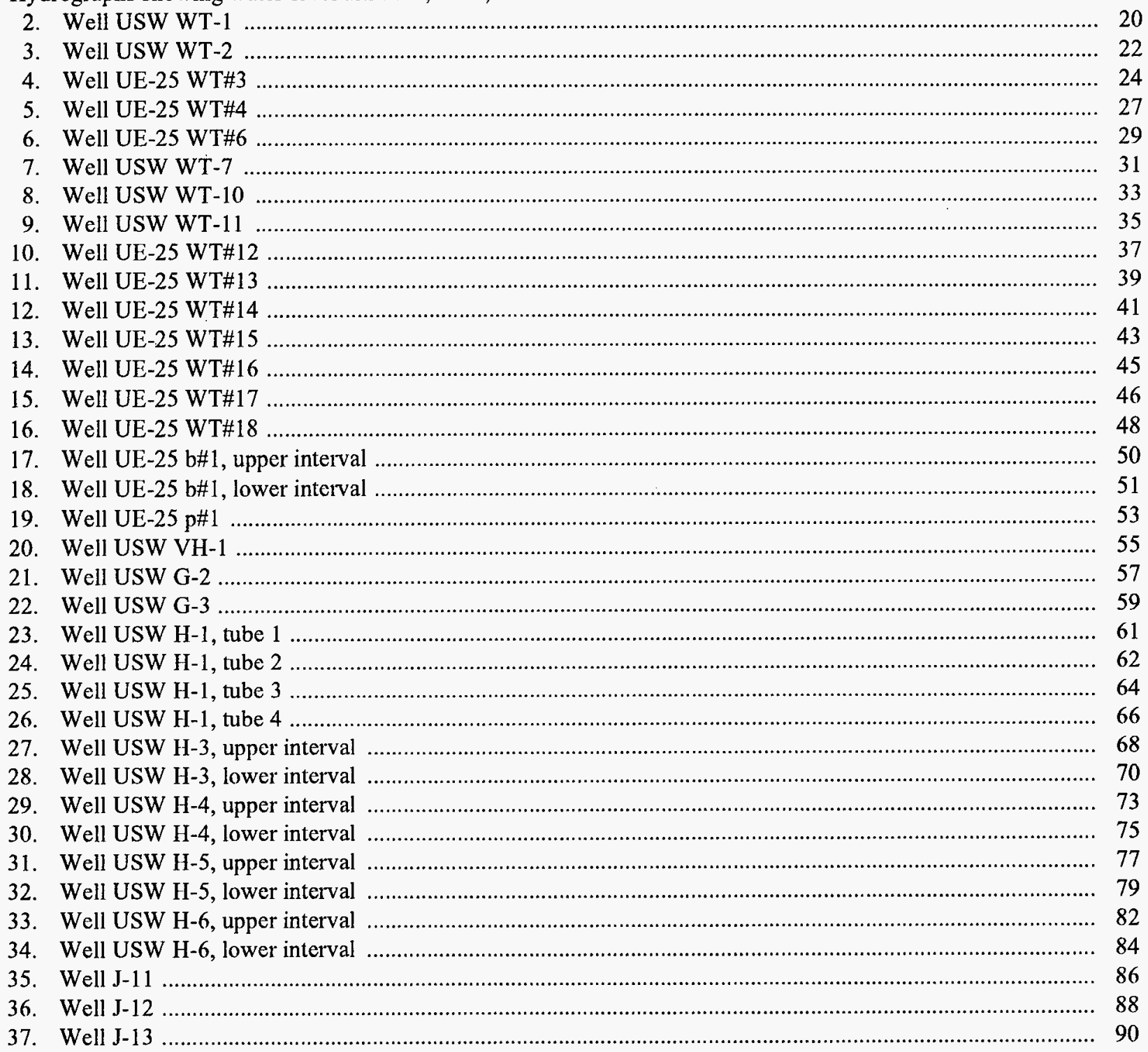

\section{TABLES}

1. Summary of wells monitored for water levels in the Yucca Mountain area, Nevada .......................................

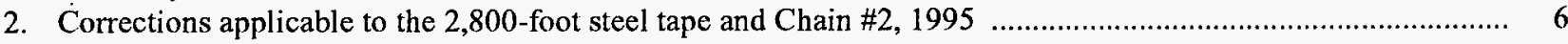

3. Corrections applicable to Chain \#3 and Chain \#4, 1995

4. Mechanical stretch and thermal expansion equation variable values for the 2,800 foot reference steel tape, Chain \#2, Chain \#3, and Chain \#4

5. Water-level measurements used to calibrate the multiconductor-cable unit

6 - 21. Mean monthly water-level altitudes, 1995 for:

6. Well USW WT-1

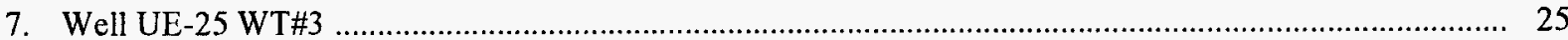

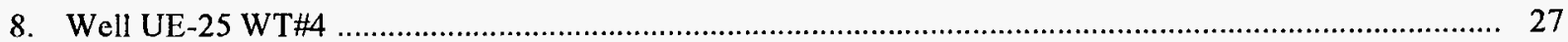




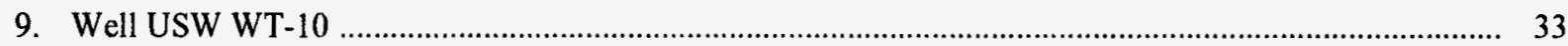

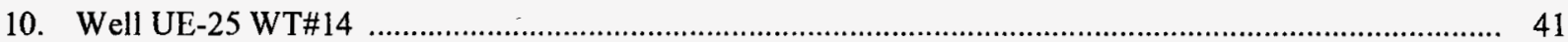

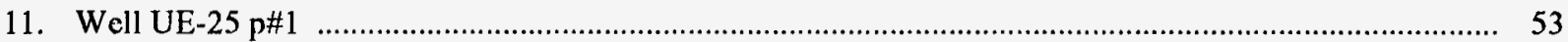

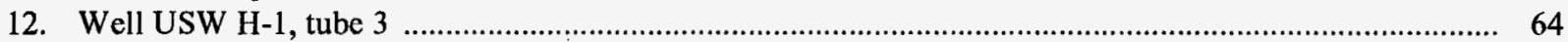

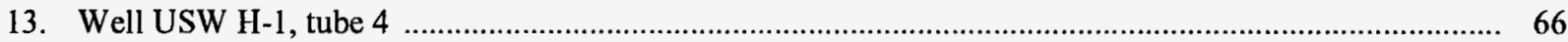

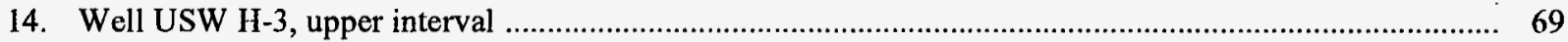

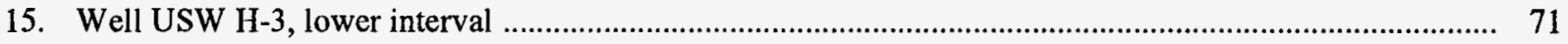

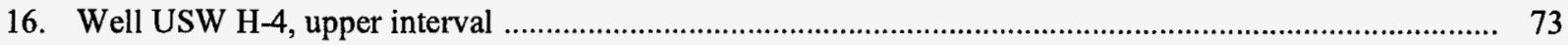

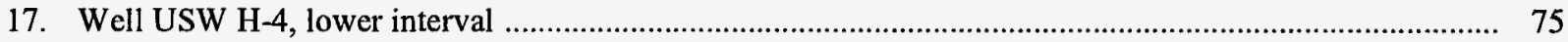

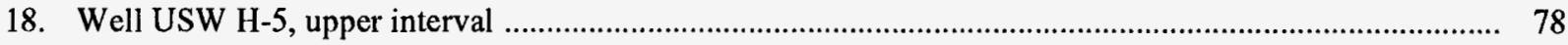

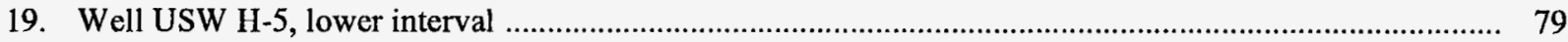

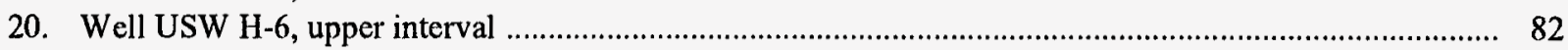

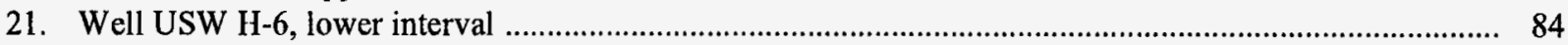

\section{CONVERSION FACTORS AND VERTICAL DATUM}

\begin{tabular}{rll}
\hline Multiply & By & To obtain \\
\hline cubic meter $\left(\mathrm{m}^{3}\right)$ & & \\
kilometer $(\mathrm{km})$ & 264.2 & gallon \\
liter $(\mathrm{L})$ & 0.6214 & mile \\
meter $(\mathrm{m})$ & 0.03531 & cubic foot \\
millimeter $(\mathrm{mm})$ & 3.281 & foot \\
pound per square inch $(\mathrm{psi})$ & 0.03937 & inch \\
square kilometer $\left(\mathrm{km}^{2}\right)$ & 003.1 & kilogram per square meter \\
& 0.3861 & square mile \\
\hline
\end{tabular}

Sea level: In this report "sea level" refers to the National Geodetic Vertical Datum of 1929 (NGVD of 1929) - a geodetic datum derived from a general adjustment of the first-order level nets of both the United States and Canada, formerly called Sea Level Datum of 1929. 


\title{
Water Levels in the Yucca Mountain Area, Nevada, 1995
}

\author{
By Robert P. Graves and Robert L. Goemaat
}

\begin{abstract}
Water levels were monitored in 28 wells in the Yucca Mountain area, Nevada, during 1995. Seventeen wells representing 18 depth intervals were monitored periodically, generally on a monthly basis, 2 wells representing 3 depth intervals were monitored hourly, and 9 wells representing 15 depth intervals were monitored both periodically and hourly. All wells monitor water levels in Tertiary volcanic rocks except one that monitors water levels in Paleozoic carbonate rocks. Water levels were measured using calibrated steel tapes, a multiconductor cable unit, and/or pressure transducers.

Mean water-level altitudes in the Tertiary volcanic rocks ranged from about 728 to about 1,034 meters above sea level during 1995. The mean water-level altitude in the well monitoring the Paleozoic carbonate rocks was about 753 meters above sea level during 1995. Mean water level altitudes were only an average of about 0.01 meters higher than 1994 mean water level altitudes. A single-well aquifer test was conducted on well UE-25 WT\#12 during August and September 1995. Well USW G-2 was also pumped during October and November 1995, in preparation for single-well aquifer test at that well. All data were acquired in accordance with a quality-assurance program to support the reliability of the data.
\end{abstract}

\section{INTRODUCTION}

The Yucca Mountain area is being evaluated by the U.S. Department of Energy for suitability to store highlevel nuclear waste in a mined, underground repository. A $150 \mathrm{~km}^{2}$ area located about $150 \mathrm{~km}$ northwest of Las Vegas in southern Nevada is being studied extensively (fig. 1). Water levels in selected wells have been measured periodically since 1981 . The purpose of the water-level monitoring program is to gain a better understanding of the ground-water flow system in the area. The water-level data will be used to determine the direction and rate of ground-water flow, and to estimate hydraulic parameters of the flow system. In the Yucca Mountain area, the water table is in air-fall and ash-flow tuffs of Tertiary age. Saturated carbonate rocks of Paleozoic age underlie the Tertiary volcanic rocks. The geology and description of stratigraphic units in the study area have been defined by Winograd and Thordarson (1975), Byers and others (1976), Carr and others (1986), and Carr (1988). The nomenclature for stratigraphic units in the study area was revised by Sawyer and others (1994), and this report uses the new revised geologic nomenclature.

This report describes the equipment and methods used during 1995 to collect and process water-level data, presents the 1995 data, and lists 1995 water-level altitudes for a network of 28 wells (fig. 1, table 1). The network has evolved into one that, in 1995 , included 17 wells representing 18 depth intervals that were monitored periodically by means of manual measurements, 2 wells representing 3 depth intervals that were equipped with transducers and monitored hourly, and 9 wells representing 15 depth intervals that were monitored both periodically and hourly. Continuous water-level and fluid-pressure data were also collected at wells USW H-5 and USW H-6, using analog-chart recorders, to allow monitoring of fluctuations caused by earthquakes; however, these continuous data are not included in this report. All wells monitor water levels in the various Tertiary volcanic rocks that underlie the Yucca Mountain area except well UE-25 p\#1, which monitors water levels in the Paleozoic carbonate rocks that underlie the volcanic rocks. 


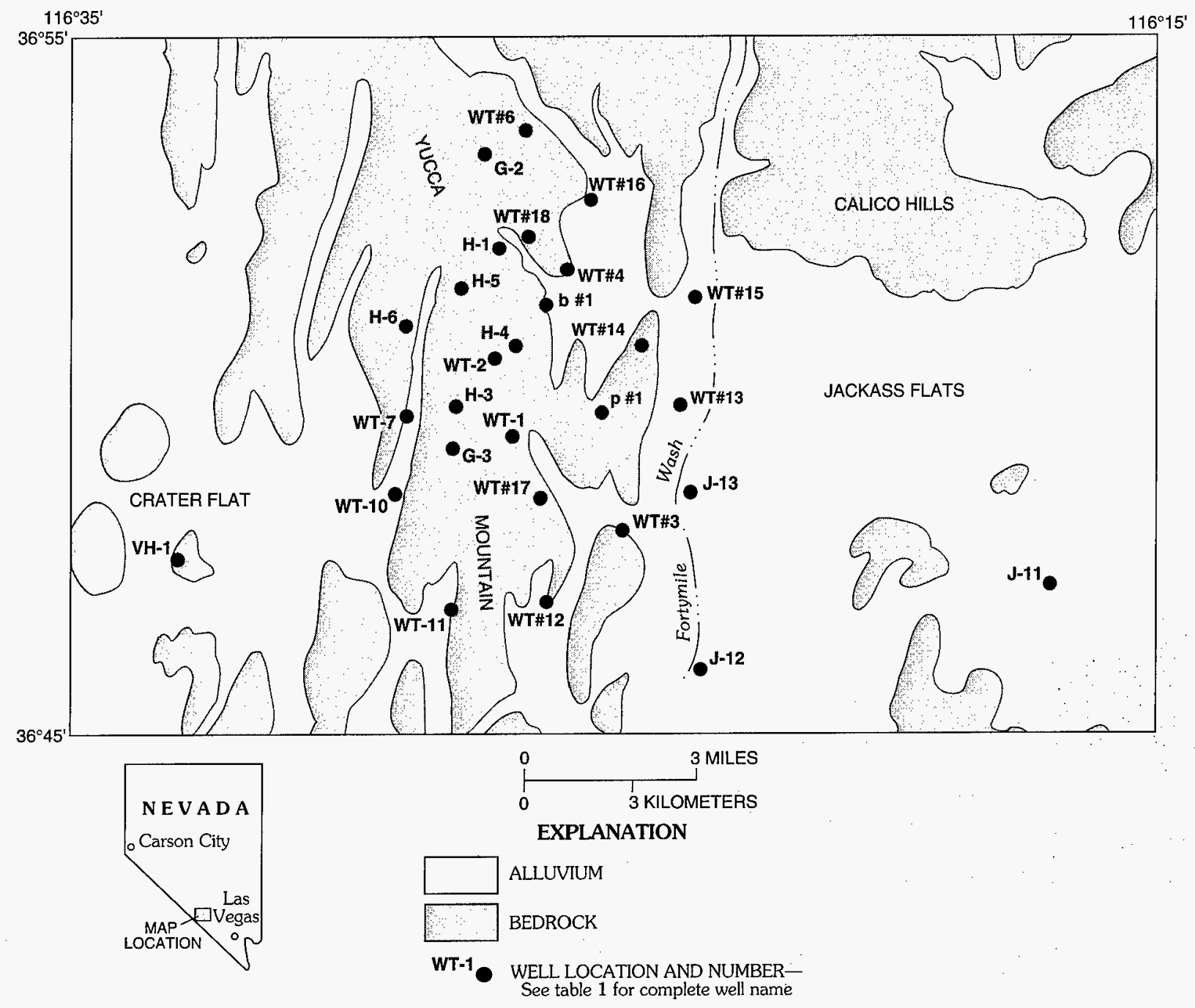

Figure 1. Location of Yucca Mountain area and location of wells.

During September 1995, all but two wells that were being monitored hourly during most of the year had data-collection equipment removed. Following removal of the equipment these wells were only measured periodically. One of these wells was well USW H-6, and during September the analog-chart recorder was also removed from this well.

Water-level data are presented as hydrographs of water-level altitudes for each well. Data sets for the hydrographs include periodic manually measured water levels and/or daily mean water levels of the hourly transducer data. The periodic manual measurements were generally made monthly, using calibrated steel tapes or a multiconductor cable. The hourly water levels were collected using pressure transducers and electronic data loggers.

This report is a companion and supplement to other reports that present water levels in the Yucca Mountain area (Robison and others, 1988; Gemmell, 1990; O'Brien, 1991; Boucher, 1994b; Luckey and others, 1993; 
Table 1. Summary of wells monitored for water levels, 1995

[p \& h, well measured periodically and hourly during 1995; p, well measured periodically during 1995; h, well measured hourly during 1995; ---, data not available]

\begin{tabular}{|c|c|c|c|c|c|c|}
\hline \multirow[b]{2}{*}{ Well name } & \multirow[b]{2}{*}{$\begin{array}{l}\text { Drilled depth } \\
\text { (meters) }\end{array}$} & \multirow[b]{2}{*}{$\begin{array}{c}\text { Depth below land } \\
\text { surface of bottom } \\
\text { of monltoring tube } \\
\text { (meters) }\end{array}$} & \multirow[b]{2}{*}{$\begin{array}{l}\text { Date completed } \\
\text { (month/year) }\end{array}$} & \multicolumn{3}{|c|}{ Water level } \\
\hline & & & & $\begin{array}{c}\text { Approximate } \\
\text { mean, 1995, depth } \\
\text { below reference } \\
\text { polnt } \\
\text { (meters) }\end{array}$ & $\begin{array}{l}\text { Approximate } \\
\text { mean, 1995, } \\
\text { altitude } \\
\text { (meters) }\end{array}$ & $\begin{array}{l}\text { Frequency } \\
\text { monitored }\end{array}$ \\
\hline USW WT-1 & 515 & $5 \overline{07.5}$ & $5 / 83$ & 471 & 730 & $\mathrm{p} \& \mathrm{~h}$ \\
\hline USW WT-2 & 628 & 622.0 & $7 / 83$ & 571 & 731 & $p$ \\
\hline UE-25 WT\#6 & 383 & 372.0 & $6 / 83$ & 280 & 1,034 & $p$ \\
\hline USW WT-7 & 491 & 481.3 & $7 / 83$ & 421 & 776 & $\mathbf{p}$ \\
\hline USW WT-10 & 431 & 402.6 & $8 / 83$ & 347 & 776 & $\mathrm{p} \& \mathrm{~h}$ \\
\hline USW WT-11 & 441 & 416.0 & $8 / 83$ & 363 & 731 & $p$ \\
\hline UE-25 WT\#1 5 & 415 & 406.9 & $11 / 83$ & 354 & 729 & $\mathbf{p}$ \\
\hline UE-25 WT\#16 & 521 & 514.0 & $11 / 83$ & 472 & 738 & $\mathrm{p}$ \\
\hline UE-25 WT\#17 & 443 & 419.4 & $10 / 83$ & 394 & 730 & $\mathrm{p}$ \\
\hline UE-25 WT\#18 & 623 & 609.0 & $5 / 84$ & 606 & 731 & $\mathrm{p}$ \\
\hline UE-25 b\#1 & 1,220 & $\cdots$ & $9 / 81$ & --- & $-\cdots$ & -- \\
\hline upper interval & -- & 488.0 & --- & 470 & 731 & $\mathrm{p}$ \\
\hline lower interval & -- & $1,199.0$ & --- & 471 & 730 & $\mathrm{p}$ \\
\hline UE-25 p\#1 & 1,805 & ${ }^{1} 418.0$ & $5 / 83$ & 362 & 753 & $\mathrm{~h}$ \\
\hline USW G-2 & 1,831 & ${ }^{2} 597.0$ & $10 / 81$ & 534 & 1,020 & $\mathrm{p}$ \\
\hline USW G-3 & 1,533 & 792.0 & $3 / 82$ & 750 & 731 & p \\
\hline lower interval & -.- & $1,114.0$ & --- & 724 & 759 & $\mathrm{p} \& \mathrm{~h}$ \\
\hline USW H-4 & 1,219 & -- & $6 / 82$ & $\ldots$ & --- & -- \\
\hline upper interval & --- & 525.0 & --- & 518 & 730 & $\mathrm{p} \& \mathrm{~h}$ \\
\hline lower interval & --- & $1,188.0$ & $-\ldots$ & 518 & 730 & $\mathrm{p} \& \mathrm{~b}$ \\
\hline USW H-5 & 1,219 & -- & $8 / 82$ & --- & --- & --- \\
\hline upper interval & --- & 709.0 & -- & 704 & 775 & $\mathrm{~h}$ \\
\hline lower interval & -.. & 846.0 & --- & 703 & 776 & $\mathbf{h}$ \\
\hline USW H-6 & 1,220 & $-\cdots$ & $10 / 82$ & --- & --- & --- \\
\hline upper interval & --- & 533.0 & --- & 526 & 776 & $\mathrm{p} \& \mathrm{~h}$ \\
\hline lower interval & --- & 752.0 & -- & 526 & 776 & $\mathrm{p} \& \mathrm{~h}$ \\
\hline
\end{tabular}


Table 1. Summary of wells monitored for water levels, 1995 - Continued

[p \& h, well measured periodically and hourly during 1995; p, well measured periodically during 1995; h, well measured hourly during 1995; ---, data not availabie]

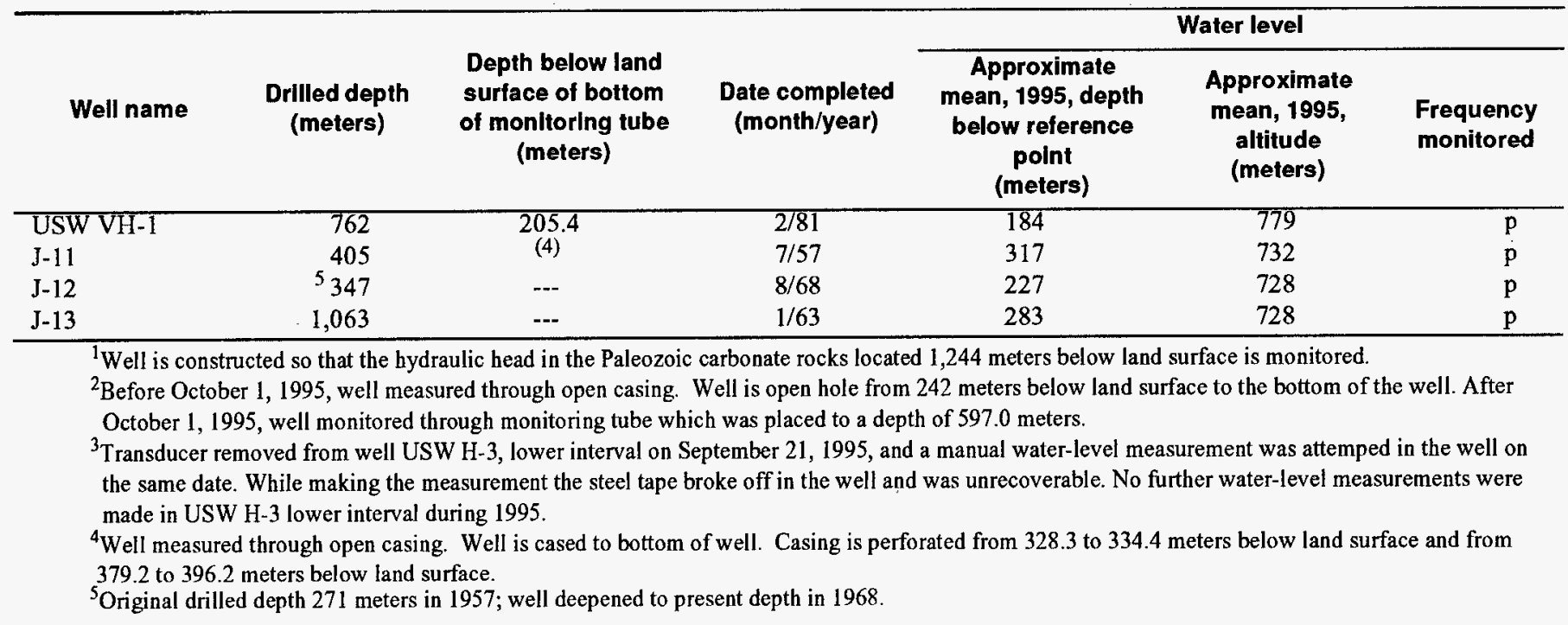

Lobmeyer and others, 1995; Tucci, O'Brien, and Burkhardt, 1996; O'Brien and others, 1995; Tucci, Goemaat, and Burkhardt, 1996; and Graves and others, 1996). Robison and others (1988) describe the details of how the manual water-level measurements were made and corrected to compute the water-level altitude.

The water-level data were obtained as part of the Yucca Mountain Project of the U.S. Department of Energy. The Yucca Mountain Project is described by a Site Characterization Plan (U.S. Department of Energy, 1988). The data in this study were collected by the U.S. Geological Survey and its contractors in cooperation with the U.S. Department of Energy under Interagency Agreement DE-AI08-92NV10874.

\section{WELL DESIGNATIONS}

Each well used in the study of the Yucca Mountain area has a unique name or number. Wells on the Nevada Test Site (NTS) use an NTS designation, whereas wells off the NTS use a slightly different designation. Wells on the NTS begin with UE (for Underground Exploratory), followed by the NTS area number (always 25 in this report). This designation-UE-25 - commonly is followed by one or more letters signifying the purpose of the well or simply by a sequential letter, followed by a sequence number. Wells off the NTS begin with the letters USW (for Underground, Southern Nevada, Waste). The designation-USW-is followed by one or more letters signifying the primary purpose of the well followed by a sequence number. The letters signifying purpose that are used in this report are $\mathrm{G}$ (collection of geologic data), $\mathrm{H}$ (collection of hydrologic data), $\mathrm{P}$ (collection of data on rocks of Paleozoic age), VH (collection of hydrologic and geologic data of volcanic rocks) and WT (collection of water-table data). The only wells not using this designation system and referred to in this report are wells J-11, $\mathrm{J}-12$, and $\mathrm{J}-13$, which were drilled as water-supply wells.

Nevada State Coordinates are used to identify the location of wells cited in this report. These coordinates are for the central zone of Nevada and are based on a Transverse Mercator projection. The origin of this projection for the central zone of Nevada is latitude $34^{\circ} 45^{\prime} \mathrm{N}$., and the central meridian is at longitude $116^{\circ} 40^{\prime} \mathrm{W}$. The Nevada State Coordinates are in meters north of the baseline and in meters, plus 152,400 east of the central meridian. The Nevada State Coordinate locations for the wells were determined by Holmes \& Narver, Inc., contractor to the U.S. Department of Energy for surveying at the NTS and Yucca Mountain area. Latitude and longitude values of the wells were calculated from the Nevada State Coordinates. 
The Site ID number is used for unique identification of the well in the U.S. Geological Survey's databases. The Site ID is generated by combining the original designations of the latitude and longitude with a two-digit sequence number. The Site ID is for convenience of identification only and should not be used as an actual location number because the original designations of latitude and longitude may be inaccurate. Even if original values of the latitude and longitude are revised later, the Site ID for the well is not changed. If more than one well exists within the 1 -second rectangle of latitude and longitude, the two-digit sequence number is used to ensure uniqueness of the Site ID.

Some wells within the water-level network have had packers or piezometers installed so the water level at discrete depth intervals can be measured. In these instances, before the packers or piezometers were installed, the well was assigned one Site ID (generally with a sequence number of 01), and, prior to 1990, each depth interval was assigned its own unique Site ID by incrementing the sequence number. Hence, some wells within the network have several Site ID's. However, since 1990, the water-level data are generally stored in the National Water Information System (NWIS) data base under the Site ID with sequence number 01. Exceptions are wells USW H-5 and UE-25 p\#1, which use the Site ID with sequence number 02. For those wells that have more than one zone monitored, the water levels are kept distinct in NWIS with the use of data descriptors which define each unique zone.

\section{DATA-COLLECTION SYSTEM}

Water-level data are collected at Yucca Mountain by means of manual periodic measurements and by use of pressure transducers that are monitored hourly by data loggers. Periodic measurements are discussed first, followed by a discussion of the pressure-transducer system. All water-level measurements are subject to various corrections, and these corrections are also discussed.

\section{Periodic Measurements}

Periodic, manual, water-level measurements at wells require visits by trained personnel, who perform specific operations and record the results. Operational plans for 1995 called for measurements about once per month at each well. Measurement frequency, however, did vary; water levels in some wells were measured less frequently because of factors such as temporary shortage of trained personnel, breakdown of equipment, or well-site inaccessibility due to road washouts. Manual water-level measurements also are made at hourly monitored wells at times of calibration or replacement of defective pressure transducers.

Periodic measurements during 1995 were made primarily with Chain \#3, which is a specially constructed reeled steel tape that is $7.9 \mathrm{~mm}$ wide and $792 \mathrm{~m}$ long. Measurements were also made with Chains \#2 and \#4, reeled steel tapes that are also $7.9 \mathrm{~mm}$ wide and $792 \mathrm{~m}$ long, the 2,800-foot reference steel tape, a reeled steel tape that is $6.4 \mathrm{~mm}$ wide and $853 \mathrm{~m}$ long, and the multiconductor cable unit. Detailed descriptions of Chain $\# 2$, the 2,800-foot reference steel tape, and the multiconductor cable unit are given by O'Brien (1991), and are not repeated here. Because of the similarities between Chains \#2, \#3, and \#4, the detailed description of Chain \#2 is considered to be the same for Chains \#3 and \#4.

\section{Corrections and Adjustments to Manual Measurements}

Various factors affect the accuracy of manual water-level measurements and are considered in the process of determining an accurate depth below land surface and the water-level altitude. All measurements in this report have been corrected to obtain the most accurate water-level altitudes. The correction factors applied to steel-tape measurements for each well are summarized in tables 2 and 3.

Corrections made for steel-tape water-level measurements include mechanical stretch and thermal expansion of the tape. Multiconductor-cable measurements are corrected using a regression equation obtained during calibration of the unit. All measurements, except those at wells $\mathrm{J}-11$, J-12, and J-13, are corrected for borehole deviation from vertical. Borehole-deviation information is not available for wells $\mathrm{J}-11$, J-12, and $\mathrm{J}-13$. All measurements are referenced to sea-level datum. 
Table 2. Corrections applicable to the 2,800-foot steel tape and Chain \#2, 1995

\begin{tabular}{|c|c|c|c|c|c|c|c|c|c|c|c|}
\hline \multirow{2}{*}{$\begin{array}{l}\text { Well name } \\
\text { (superscript is } \\
\text { tube \# or } \\
\text { Interval) }\end{array}$} & \multirow{2}{*}{$\begin{array}{c}\text { Assumed } \\
\text { average air } \\
\text { temperature, } \\
\text { in well } \\
\text { (degrees } \\
\text { Celsius) }\end{array}$} & \multicolumn{3}{|c|}{$\begin{array}{l}\text { Correction for 2,800-foot } \\
\text { reference steel tape } \\
\text { (meters) }\end{array}$} & \multicolumn{3}{|c|}{$\begin{array}{l}\text { Correction for Chain \#2 } \\
\text { (meters) }\end{array}$} & \multirow{2}{*}{$\begin{array}{l}\text { Correction } \\
\text { for hole } \\
\text { deviation } \\
\text { from vertical } \\
\text { (meters) }\end{array}$} & \multicolumn{2}{|c|}{$\begin{array}{c}\begin{array}{c}\text { Measuring point } \\
\text { (meters) }\end{array} \\
\text { Interval }^{2}\end{array}$} & \multirow{2}{*}{$\begin{array}{c}\text { Reference } \\
\text { point } \\
\text { (meters) }\end{array}$} \\
\hline & & $\begin{array}{l}\text { Mechanical } \\
\text { stretch }\end{array}$ & $\begin{array}{l}\text { Thermal } \\
\text { expansion }\end{array}$ & Total $^{1}$ & $\begin{array}{l}\text { Mechanical } \\
\text { stretch }\end{array}$ & $\begin{array}{l}\text { Thermal } \\
\text { expansion }\end{array}$ & Total $^{1}$ & & Upper & Lower & \\
\hline USWWT-1 & 25.0 & -0.043 & 0.027 & -0.016 & -0.020 & 0.027 & 0.008 & -0.326 & 0.314 & -- & $1,201.11$ \\
\hline USW WT-2 & 24.4 & -0.038 & 0.029 & -0.009 & -0.012 & 0.029 & 0.017 & -0.445 & 0.311 & -- & $1,301.13$ \\
\hline UE-25 WT\#3 & 26.1 & -0.041 & 0.021 & -0.020 & -0.024 & 0.021 & -0.002 & -0.271 & 0.155 & - & $1,030.11$ \\
\hline UE-25 WT\#4 & 25.0 & -0.044 & 0.025 & -0.019 & -0.021 & 0.025 & 0.004 & -0.454 & 0.311 & - & $1,169.21$ \\
\hline UE-25 WT\#6 & 23.3 & -0.040 & 0.011 & -0.029 & -0.023 & 0.011 & -0.012 & -0.204 & 0.463 & -- & $1,314.78$ \\
\hline USW WT-7 & 27.8 & -0.044 & 0.038 & -0.006 & -0.022 & 0.038 & 0.016 & -0.034 & 0.302 & -- & $1,196.88$ \\
\hline USW WT-10 & 29.4 & -0.043 & 0.038 & -0.005 & -0.024 & 0.038 & 0.014 & -0.030 & 0.314 & -- & $1,123.40$ \\
\hline USW WT-11 & 28.3 & -0.044 & 0.035 & -0.009 & -0.024 & 0.035 & 0.011 & -0.116 & 0.311 & -- & $1,094.11$ \\
\hline UE-25 WT\#12 & 27.2 & -0.043 & 0.029 & -0.014 & -0.024 & 0.029 & 0.005 & -0.183 & $0.171^{3}$ & -- & $1,074.74$ \\
\hline UE-25 WT\#13 & 24.4 & -0.041 & 0.015 & -0.026 & -0.024 & 0.015 & -0.008 & -0.012 & 0.305 & -- & $1,032.51$ \\
\hline UE-25 WT\#14 & 24.4 & -0.043 & 0.018 & -0.025 & -0.024 & 0.018 & -0.006 & -0.085 & 0.311 & -- & $1,076.05$ \\
\hline UE-25 WT\#15 & 23.9 & -0.043 & 0.016 & -0.027 & -0.024 & 0.016 & -0.008 & -0.189 & 0.314 & -- & $1,082.94$ \\
\hline UE-25 WT\#16 & 26.1 & -0.043 & 0.033 & -0.010 & -0.020 & 0.033 & 0.014 & -0.064 & 0.314 & -- & $1,210.63$ \\
\hline UE-25 WT\#17 & 25.0 & -0.044 & 0.023 & -0.021 & -0.023 & 0.023 & 0.000 & -0.482 & 0.158 & -- & $1,124.06$ \\
\hline UE-25 WT\#18 & 25.1 & -0.035 & 0.036 & 0.001 & -0.008 & 0.036 & 0.028 & -0.155 & 0.210 & -- & $1,336.32$ \\
\hline UE-25 b\#1 & 25.6 & -0.043 & 0.031 & -0.013 & -0.020 & 0.031 & 0.011 & -0.244 & 0.302 & 0.134 & $1,200.73$ \\
\hline UE-25 p\#1 & 25.6 & -0.044 & 0.024 & -0.020 & -0.024 & 0.023 & 0.000 & -0.021 & 0.158 & -- & $1,114.21$ \\
\hline USW G-2 & 22.8 & -0.041 & 0.017 & -0.024 & -0.016 & 0.017 & 0.001 & -0.192 & $0.198^{4}$ & & $1,553.86$ \\
\hline USW G-3 & 23.3 & -0.015 & 0.029 & 0.013 & 0.014 & 0.029 & 0.042 & -0.564 & 0.329 & -- & $1,480.47$ \\
\hline USW H-1 ${ }^{\text {tube } 1}$ & 25.0 & -0.042 & 0.030 & -0.012 & -0.016 & 0.030 & 0.014 & -0.143 & 0.311 & -- & $1,303.10$ \\
\hline USW H-1 $1^{\text {tube } 2}$ & 25.0 & -0.038 & 0.033 & -0.005 & -0.012 & 0.033 & 0.021 & -0.171 & 0.311 & -- & $1,303.10$ \\
\hline USW H-1 ${ }^{\text {tubes }} 3,4$ & 25.0 & -0.038 & 0.033 & -0.005 & -0.012 & 0.033 & 0.022 & -0.174 & 0.311 & -- & $1,303.10$ \\
\hline USW H-3 $3^{\text {upper }}$ & 26.1 & -0.015 & 0.053 & 0.038 & 0.014 & 0.053 & 0.067 & -0.079 & 0.174 & -- & $1,483.47$ \\
\hline USW H-3 ${ }^{\text {lower }}$ & 26.1 & -0.019 & 0.052 & 0.033 & 0.010 & 0.052 & 0.061 & -0.058 & -- & 0.201 & $1,483.47$ \\
\hline USW H-4 & 24.4 & -0.042 & 0.026 & -0.015 & -0.016 & 0.026 & 0.010 & -0.064 & 0.597 & 0.308 & $1,248.74$ \\
\hline USW H-5 & 23.9 & -0.023 & 0.032 & 0.009 & 0.006 & 0.032 & 0.037 & -0.079 & 0.329 & 0.235 & $1,478.94$ \\
\hline USW H-6 & 25.0 & -0.041 & 0.031 & -0.011 & -0.016 & 0.031 & 0.015 & -0.052 & 0.207 & 0.235 & $1,302.06$ \\
\hline USW VH-1 & 23.9 & -0.031 & 0.008 & -0.022 & -0.019 & 0.008 & -0.011 & -0.049 & 0.631 & -- & 963.23 \\
\hline Well J-11 & 25.0 & -0.042 & 0.018 & -0.023 & -0.024 & 0.018 & -0.005 & unknown & 0.555 & -- & $1,049.45$ \\
\hline Well J-12 & 25.0 & -0.035 & 0.013 & -0.022 & -0.021 & 0.013 & $-0,008$ & unknown & $0.195^{5}$ & -- & 954.54 \\
\hline Well J-13 & 25.0 & -0.040 & 0.016 & -0.023 & -0.023 & 0.016 & -0.007 & unknown & 0.165 & -- & $1,011.47$ \\
\hline
\end{tabular}

${ }^{1}$ Total correction may not equal sum of mechanical stretch and thermal expansion due to rounding

${ }^{2}$ Wells with only one interval have measuring point listed as upper.

${ }^{3}$ Measuring point 0.305 meters 01-01-95 through 07-07-95 and 0.171 meters 07-28-95 through 12-31-95.

${ }^{4}$ Measuring point 0.332 meters $01-01-95$ through $10-01-95$ and 0.198 meters $10-02-95$ through $12-31-95$.

${ }^{5}$ Measuring point 0.527 meters before 10-01-95, after 10-01-95 measuring point 0.195 meters. 
Table 3. Corrections applicable to Chain \#3 and Chain \#4, 1995

[--, not applicable]

\begin{tabular}{|c|c|c|c|c|c|c|c|c|c|c|c|}
\hline \multirow{2}{*}{$\begin{array}{l}\text { Well name } \\
\text { (superscript is } \\
\text { tube * or } \\
\text { interval) }\end{array}$} & \multirow{2}{*}{$\begin{array}{c}\text { Assumed } \\
\text { average air } \\
\text { temperature, } \\
\text { In well } \\
\text { (degrees } \\
\text { Celsius) }\end{array}$} & \multicolumn{3}{|c|}{$\begin{array}{l}\text { Correction for Chain \#3 } \\
\text { (meters) }\end{array}$} & \multicolumn{3}{|c|}{$\begin{array}{l}\text { Correctlon for Chain \#4 } \\
\text { (meters) }\end{array}$} & \multirow{2}{*}{$\begin{array}{l}\text { Correction } \\
\text { for hole } \\
\text { deviation } \\
\text { from vertical } \\
\text { (meters) }\end{array}$} & \multicolumn{2}{|c|}{$\begin{array}{c}\begin{array}{c}\text { Measuring point } \\
\text { (meters) }\end{array} \\
\text { Interval }^{2}\end{array}$} & \multirow{2}{*}{$\begin{array}{c}\text { Reference } \\
\text { point } \\
\text { (meters) }\end{array}$} \\
\hline & & $\begin{array}{l}\text { Mechanical } \\
\text { stretch }\end{array}$ & $\begin{array}{l}\text { Thermal } \\
\text { expansion }\end{array}$ & Total $^{1}$ & $\begin{array}{l}\text { Mechanical } \\
\text { stretch }\end{array}$ & $\begin{array}{l}\text { Thermal } \\
\text { expansion }\end{array}$ & Total ${ }^{1}$ & & Upper & Lower & \\
\hline USW WT-1 & 25.0 & -0.019 & 0.027 & 0.008 & -0.019 & 0.027 & 0.008 & -0.326 & 0.314 & -- & $1,201.11$ \\
\hline USW WT-2 & 24.4 & -0.010 & 0.029 & 0.019 & -0.011 & 0.029 & 0.018 & -0.445 & 0.311 & -- & $1,301.13$ \\
\hline UE-25 WT\#3 & 26.1 & -0.024 & 0.021 & -0.002 & -0.024 & 0.021 & -0.002 & -0.271 & 0.155 & -- & $1,030.11$ \\
\hline UE-25 WT\#4 & 25.0 & -0.021 & 0.025 & 0.004 & -0.021 & 0.025 & 0.004 & -0.454 & 0.311 & -- & $1,169.21$ \\
\hline UE-25 WT\#6 & 23.3 & -0.023 & 0.011 & -0.012 & -0.023 & 0.011 & -0.013 & -0.204 & 0.463 & -- & $1,314.78$ \\
\hline USW WT-7 & 27.8 & -0.022 & 0.038 & 0.016 & -0.022 & 0.038 & 0.016 & -0.034 & 0.302 & -- & $1,196.88$ \\
\hline USW WT-10 & 29.4 & -0.024 & 0.038 & 0.014 & -0.024 & 0.038 & 0.014 & -0.030 & 0.314 & -- & $1,123.40$ \\
\hline USW WT-11 & 28.3 & -0.023 & 0.035 & 0.012 & -0.024 & 0.035 & 0.012 & -0.116 & 0.311 & -- & $1,094.11$ \\
\hline UE-25 WT\#12 & 27.2 & -0.024 & 0.029 & 0.005 & -0.024 & 0.029 & 0.005 & -0.183 & $0.171^{3}$ & -- & $1,074.74$ \\
\hline UE-25 WT\#13 & 24.4 & -0.024 & 0.015 & -0.008 & -0.024 & 0.016 & -0.008 & -0.012 & 0.305 & -- & $1,032.51$ \\
\hline UE-25 WT\#14 & 24.4 & -0.024 & 0.018 & -0.006 & -0.024 & 0.018 & -0.006 & -0.085 & 0.311 & -- & $1,076.05$ \\
\hline UE-25 WT\#15 & 23.9 & -0.024 & 0.016 & -0.008 & -0.024 & 0.016 & -0.008 & -0.189 & 0.314 & -- & $1,082.94$ \\
\hline UE-25 WT\#16 & 26.1 & -0.019 & 0.033 & 0.015 & -0.019 & 0.034 & 0.014 & -0.064 & 0.314 & -- & $1,210.63$ \\
\hline UE-25 WT\#17 & 25.0 & -0.023 & 0.023 & 0.000 & -0.023 & 0.023 & 0.000 & -0.482 & 0.158 & -- & $1,124.06$ \\
\hline UE-25 WT\#18 & 25.1 & -0.006 & 0.036 & 0.030 & -0.007 & 0.035 & 0.028 & -0.155 & 0.210 & -- & $1,336.32$ \\
\hline UE-25 b\#1 & 25.6 & -0.019 & 0.031 & 0.012 & -0.019 & 0.030 & 0.011 & -0.244 & 0.302 & 0.134 & $1,200.73$ \\
\hline UE-25 p\#1 & 25.6 & -0.023 & 0.023 & 0.000 & -0.024 & 0.023 & 0.000 & -0.021 & 0.158 & -- & $1,114.21$ \\
\hline USW G-2 & 22.8 & -0.015 & 0.017 & 0.002 & -0.015 & 0.017 & 0.001 & -0.192 & $0.198^{4}$ & & $1,553.86$ \\
\hline USW G-3 & 23.3 & 0.017 & 0.029 & 0.045 & 0.015 & 0.029 & 0.044 & -0.564 & 0.329 & -- & $1,480.47$ \\
\hline USW H-1 ${ }^{\text {tube } 1}$ & 25.0 & -0.015 & 0.030 & 0.015 & -0.016 & 0.027 & 0.011 & -0.143 & 0.311 & -- & $1,303.10$ \\
\hline USW H-1 ${ }^{\text {tube } 2}$ & 25.0 & -0.011 & 0.033 & 0.022 & -0.011 & 0.033 & 0.022 & -0.171 & 0.311 & -- & $1,303.10$ \\
\hline USW H-1 ${ }^{\text {tubes } 3,4}$ & 25.0 & -0.010 & 0.033 & 0.023 & -0.011 & 0.033 & 0.022 & -0.174 & 0.311 & -- & $1,303.10$ \\
\hline USW H-3 $3^{\text {upper }}$ & 26.1 & 0.017 & 0.053 & 0.070 & 0.016 & 0.053 & 0.069 & -0.079 & 0.174 & -- & $1,483.47$ \\
\hline USW H-3 ${ }^{\text {lower }}$ & 26.1 & 0.013 & 0.052 & 0.064 & 0.011 & 0.052 & 0.062 & -0.058 & -- & 0.201 & $1,483.47$ \\
\hline USW H-4 & 24.4 & -0.015 & 0.026 & 0.011 & -0.016 & 0.027 & 0.011 & -0.064 & 0.597 & 0.308 & $1,248.74$ \\
\hline USW H-5 & 23.9 & 0.008 & 0.032 & 0.040 & 0.007 & 0.032 & 0.039 & -0.079 & 0.329 & 0.235 & $1,478.94$ \\
\hline USW H-6 & 25.0 & -0.015 & 0.031 & 0.016 & -0.015 & 0.031 & 0.015 & -0.052 & 0.207 & 0.235 & $1,302.06$ \\
\hline USW VH-1 & 23.9 & -0.019 & 0.008 & -0.011 & -0.019 & 0.008 & -0.011 & -0.049 & 0.631 & -- & 963.23 \\
\hline Well J-11 & 25.0 & -0.024 & 0.018 & -0.005 & -0.024 & 0.018 & -0.005 & unknown & 0.555 & -- & $1,049.45$ \\
\hline Well J-12 & 25.0 & -0.022 & 0.013 & -0.008 & -0.022 & 0.013 & -0.008 & unknown & $0.195^{5}$ & -- & 954.54 \\
\hline Well J-13 & 25.0 & -0.023 & 0.016 & -0.007 & -0.023 & 0.016 & -0.007 & unknown & 0.165 & -- & $1,011.47$ \\
\hline
\end{tabular}

${ }^{1}$ Total correction may not equal sum of mechanical stretch and thermal expansion due to rounding

${ }^{2}$ Wells with only one interval have measuring point listed as upper.

${ }^{3}$ Measuring point 0.305 meters 01-01-95 through 07-07-95 and 0.171 meters 07-28-95 through 12-31-95.

${ }^{4}$ Measuring point 0.332 meters 01-01-95 through 10-01-95 and 0.198 meters 10-02-95 through 12-31-95.

${ }^{5_{1}}$ Measusring point 0.527 meters before $10-01-95$, after $10-01-95$ measuring point 0.195 meters. 


\section{Mechanical Stretch}

Mechanical stretch is associated with the weight of the suspended steel tape and attached plumb bob (Garber and Koopman, 1968, and Robison and others, 1988). The calculated adjustment for the steel tapes used during 1995, based on stretch coefficients and an approximate weight of $0.45 \mathrm{~kg}$ for the plumb bob for Chains \#2 and \#3 and the 2,800 foot reference steel tape, and $0.36 \mathrm{~kg}$ for Chain \#4, ranged from -0.044 to $+0.017 \mathrm{~m}$ (tables 2 and 3) for water levels measured in the vicinity of Yucca Mountain.

The correction for mechanical stretch of the tape is given by:

$$
\mathrm{C}=\left(\mathrm{L}^{2} \mathrm{WS}\right) / 2+\mathrm{PLS}-\mathrm{KLS}
$$

where,

$\mathrm{C}$ is the correction, in meters;

$\mathrm{L}$ is the apparent length of tape, in meters;

$\mathrm{W}$ is the unit weight of the tape, in kilograms per meter;

$S$ is the stretch coefficient, in meters per (meter kilogram);

$\mathrm{P}$ is the weight of the plumb bob, in kilograms; and

$\mathrm{K}$ is reference tension during manufacture, in kilograms.

The apparent length of tape (L) corresponds to the depth to water in each well. Values for W were determined at a calibration laboratory at the NTS, and values for S were determined by the U.S. Geological Survey and are estimated to be accurate to 7 percent (R.R. Luckey, U.S. Geological Survey, oral commun., 1993). Values for the reference tension $(\mathrm{K})$ are provided by the manufacturer at the time of purchase.

\section{Thermal Expansion}

Thermal expansion of a steel tape occurs because of temperature changes. The calculated correction for thermal expansion for steel tapes is based on manufacturer specifications for thermal-expansion coefficients and on average hole temperatures calculated from temperature profiles in wells at Yucca Mountain (Garber \& Koopman, 1968, and Sass and Lachenbruch, 1982). The correction ranges from +0.008 to $+0.053 \mathrm{~m}$ (tables 2 and 3).

Correction for thermal expansion of the tape is given by:

$$
E=(D-R) T L
$$

where,

$\mathrm{E}$ is the correction, in meters;

$\mathrm{D}$ is the assumed average air temperature in the well, in degrees Celsius;

$\mathrm{R}$ is the reference temperature during manufacture, in degrees Celsius;

$\mathrm{T}$ is the thermal expansion coefficient, in meters per meter-degree Celsius; and

$\mathrm{L}$ is the apparent length of the tape, in meters.

Equation 2 differs from that of Garber \& Koopman $(1968$, p. 4). The correction for thermal expansion in their report was subtracted from the measured depth to water when it should have been added (J.H. Robison, U.S. Geological Survey, written commun., 1985).

The tape corrections, which include mechanical stretch and thermal expansion, and average air temperature in the well, are given in tables 2 and 3 . Approximate depth to water is analogous to apparent length of the tape, $\mathrm{L}$, in equations 1 and 2 . The tape-dependent variables for equations 1 and 2 are defined for each tape in table 4 . 
Table 4. Mechanical stretch and thermal expansion equation variable values for the 2,800 foot reference steel tape, Chain \#2, Chain \#3 and Chain \#4.

\begin{tabular}{lcc}
\hline \multicolumn{1}{c}{ Varlable } & $\begin{array}{c}2,800 \text {-foot } \\
\text { reference steel tape }\end{array}$ & Chain \#2 \\
\hline Unit weight of the tape, W (kilogram/meter) & $2.08 \times 10^{-2}$ & $2.59 \times 10^{-2}$ \\
Stretch coefficient, S [meter/(meter kilogram)] & $2.48 \times 10^{-5}$ & $1.66 \times 10^{-5}$ \\
Weight of plumb bob, P (kilogram) & 0.45 & 0.45 \\
Reference tension during manufacture, K (kilogram) & 9.07 & 9.07 \\
Reference temperature during manufacture, R (degree Celsius) & 20 & 20 \\
Thermal expansion coefficient, T [meter/(meter degree Celsius)] & $1.16 \times 10^{-5}$ & $1.16 \times 10^{-5}$ \\
& & \\
\hline \multicolumn{1}{c}{ Variable } & Chain \#3 & Chain \#4 \\
\hline Unit weight of the tape, W (kilogram/meter) & $2.65 \times 10^{-2}$ & $2.64 \times 10^{-2}$ \\
Stretch coefficient, S [meter/(meter kilogram)] & $1.69 \times 10^{-5}$ & $1.67 \times 10^{-5}$ \\
Weight of plumb bob, P (kilogram) & 0.45 & 0.36 \\
Reference tension during manufacture, K (kilogram) & 9.07 & 9.07 \\
Reference temperature during manufacture, R (degree Celsius) & 20 & 20 \\
Thermal expansion coefficient, T [meter/(meter degree Celsius)] & $1.16 \times 10^{-5}$ & $1.16 \times 10^{-5}$ \\
\hline
\end{tabular}

\section{Multiconductor-Cable Correction}

Water-level measurements were made with the multiconductor-cable unit and the 2,800-foot reference steel tape at three wells between August 1 and 9, 1995, to calculate a correction factor for the multiconductor-cable unit (table 5). The range of depth to water in the wells measured span the range normally found in the Yucca Mountain area. The correction factor for the multiconductor-cable unit was determined by subtracting the multiconductorcable unit depth-to-water measurement from the 2,800 -foot reference steel tape measurement. The difference was then graphed and a regression analysis was performed on the data to determine the equation for the correction factor. The equation determined is:

$$
y=-0.0020176 x+0.14
$$

where,

$y$ is the correction factor, in meters, and

$\mathrm{x}$ is the apparent depth to water, in meters.

Table 5. Water-level measurements used to calibrate the multiconductor-cable unit.

\begin{tabular}{lccc}
\hline Well name & $\begin{array}{c}\text { Date water-level } \\
\text { measurement made }\end{array}$ & $\begin{array}{c}\text { Depth to water below } \\
\text { reference point of 2,800-foot } \\
\text { reference steel tape } \\
\text { (meters) }\end{array}$ & $\begin{array}{c}\text { Depth to water below } \\
\text { reference point of } \\
\text { multiconductor cable unlt } \\
\text { (meters) }\end{array}$ \\
\hline USW H-3, lower interval & $08-09-95$ & 724.10 & 725.43 \\
UE-25 WTH16 & $08-02-95$ & 472.33 & 473.13 \\
UE-25 WT\#6 & $08-01-95$ & 280.24 & 280.68 \\
\hline
\end{tabular}


For example, if the apparent depth to water is $300 \mathrm{~m}$, the correction factor is $-0.47 \mathrm{~m}$. This correction factor is applied in place of the mechanical stretch and thermal expansion corrections for the steel tapes, however, the borehole-deviation correction is applied.

Because of a broken float switch, the multiconductor-cable unit was taken out of service and repaired during January 1995. The breakdown of equipment occurred just after the unit was calibrated. Following the repair of the multiconductor-cable unit, the unit was not calibrated before being used to collect water-level data. It was not until August 1995 that the error was realized and the unit calibrated. Following the August calibration, all water-level measurements collected between January and August 1995 were reviewed with the August 1995 correction factor applied to the data. The review of data indicated that water-level measurements made with the multiconductor-cable unit prior to the August calibration were good.

Sheave slippage occurs with the multiconductor cable because of change in diameter of the sheave or operator error. Slippage can vary with hoist design, but errors can be minimized by comparing IN and OUT readings of water levels. The sheaves used for depth indicators can wear, eventually causing measurement errors. Annual calibration of the multiconductor-cable unit decreases this error and, along with visual inspection of the sheave, indicates when the sheave needs to be replaced. This factor is not applicable to steel tapes that have permanently marked units.

\section{Borehole-Deviation Correction}

In addition to the corrections for mechanical stretch, thermal expansion, and multiconductor- cable correction, corrections must also be made for boreholes that are not vertical (borehole deviation). Gyroscopic surveys were made in all measured wells except wells $\mathrm{J}-11, \mathrm{~J}-12$, and $\mathrm{J}-13$. The gyroscopic surveys measured borehole deviation from vertical. The difference between measured depth and true vertical depth is the borehole deviation, or borehole correction. Corrections range from -0.01 to $-0.56 \mathrm{~m}$ (tables 2 and 3 ). Corrections generally increase with increasing well depth.

\section{Water-Level Altitudes}

Water-level altitudes are calculated by subtracting the corrected depth to water from the altitude of the reference point. The reference point generally is a metal tag on the well casing located at or near land surface. The measuring point for the wells, at the top of the access tube, is at some distance above the reference point, and the height of the measuring point is subtracted from the apparent depth to water to calculate the corrected depth to water. Reference-point and measuring-point values for all wells are listed in tables 2 and 3, and described in the individual well sections. Water-level altitudes in this report generally are based on a survey of the water-level monitoring network reference points made in late 1984 by the U.S. Geological Survey.

\section{Example Calculations}

Example measurements for well USW WT-2 for March 24, 1995, and for well UE-25 b\#1, lower interval for March 8, 1995, are presented to illustrate the calculations made to derive the altitude of the water level. The units of measurement for the steel tapes and multiconductor cable unit are feet. All water-level measurements are recorded to the nearest 0.01 foot and later converted to meters. The calculated altitude is the value reported in the section "Well Data and Water Levels."

At least two measurements of the water level are made and averaged during each visit to the well, and the appropriate corrections are applied after averaging the water-level measurements. When either Chains \#2, \#3, or \#4 or the 2,800 foot reference steel tape are used, additional measurements are made only if the two measured depths differ by more than 1 part in 10,000 for measurements of more than 1,000 feet, or more than 0.1 foot for measurements less than 1,000 feet. When the multiconductor cable unit is used additional measurements are made if the difference in water level is more than 0.50 feet. 


\section{Example A: Chain \#3}

The water-level measurement on March 24, 1995, at USW WT-2 was made with Chain \#3. The HELD is the indicated footage on the tape when it is held at the MP during a measurement, and CUT is the footage of tape that is wetted during its submersion in the water. The difference between HELD and CUT is the apparent depth to water below the MP.

\begin{tabular}{|c|c|c|c|}
\hline Reading & $\begin{array}{c}\text { Measurement } \\
1\end{array}$ & $\begin{array}{c}\text { Measurement } \\
2\end{array}$ & \\
\hline HELD (ft) & $1,879.00$ & $1,880.00$ & \\
\hline CUT (ft) & -4.74 & -5.75 & \\
\hline Apparent depth to water $(\mathrm{ft})$ & $1,874.26$ & $1,874.25$ & \\
\hline Average of two apparent depths to water (ft) & & & $1,874.26$ \\
\hline Apparent depth to water $(1,874.26 \mathrm{ft} \times 0.3048 \mathrm{~m} / \mathrm{ft})(\mathrm{m})$ & & & 571.274 \\
\hline Measuring point $(\mathrm{m})($ table 3 ) & & & -0.311 \\
\hline Tape correction (m) (table 3 ) & & & +0.019 \\
\hline Correction for borehole deviation from vertical (m) (table 3) & & & -0.445 \\
\hline Corrected depth below reference point $(\mathrm{m})$ & & & 570.537 \\
\hline \multicolumn{4}{|l|}{ Determination of water-level altitude: } \\
\hline Altitude of reference point (m) (table 3 ) & & & $1,301.13$ \\
\hline Corrected depth (m) & & & -570.54 \\
\hline Altitude of water level (m) & & & 730.59 \\
\hline
\end{tabular}

\section{Example B: Multiconductor cable}

The water-level measurement on March 8, 1995, at UE-25 b\#1, lower interval was made with the multiconductor-cable unit. The IN reading is the indicated footage of the cable displayed by the depth indicator when the sensing device (generally a float switch) is at the water surface. The OUT reading is the indicated footage when the sensing device has been withdrawn to the MP. The measurements and corrections for UE-25 b\#1, lower interval on March 8, 1995, were:

\begin{tabular}{|c|c|c|c|}
\hline Reading & $\begin{array}{c}\text { Measurement } \\
1\end{array}$ & $\begin{array}{c}\text { Measurement } \\
2\end{array}$ & \\
\hline IN reading $(\mathrm{ft})$ & $1,546.64$ & $1,546.64$ & \\
\hline OUT reading $(\mathrm{ft})$ & -3.81 & -3.87 & \\
\hline Tool length $(\mathrm{ft})$ & +4.67 & +4.67 & \\
\hline Apparent depth to water (ft) & $1,547.50$ & $1,547.44$ & \\
\hline Average of two apparent depths to water (ft) & & & $1,547.470$ \\
\hline Apparent depth to water $(1,547.470 \mathrm{ft} \times 0.3048 \mathrm{~m} / \mathrm{ft})(\mathrm{m})$ & & & 471.669 \\
\hline Measuring point (m) (table 2$)$ & & & -0.134 \\
\hline Cable correction $(\mathrm{m})$ & & & -0.811 \\
\hline Correction for borehole deviation from vertical (m) (table 2) & & & -0.244 \\
\hline Corrected depth below reference point $(\mathrm{m})$ & & & 470.480 \\
\hline \multicolumn{4}{|l|}{ Determination of water-level altitude: } \\
\hline Altitude of reference point (m) (table 2) & & & $1,200.73$ \\
\hline Corrected depth (m) & & & -470.48 \\
\hline Altitude of water level (m) & & & 730.25 \\
\hline
\end{tabular}




\section{Precision and Accuracy}

An analysis of precision and accuracy of field data was conducted for manual water-level measurements, which include all periodic measurements obtained during 1988-90 (Boucher, 1994a). The mean precision range of the 2,800-ft reference steel tape, based on 31 measurements, was $0.026 \mathrm{ft}$ (because of changes in accuracy due to conversion to metric units and rounding of conversions, this discussion of precision and accuracy is in the units of the referenced report). The mean precision range of Chain \#2, based on 341 measurements, was $0.014 \mathrm{ft}$. Ninety-seven percent of all measurements obtained with the steel tapes were precise to within $0.05 \mathrm{ft}$ during 1988-90. The precision of Chains \#3 or \#4 are not known, but are believed to be the same or nearly the same as that of Chain \#2 because each chain has nearly the same physical characteristics and because they were identically constructed.

The overall accuracy of the computed water-level altitude depends on the individual accuracies of its computational components such as: (1) water-level measurement, (2) borehole correction, (3) height of the measuring point, (4) altitude of the reference point, and (5) the precision of the $2,800-\mathrm{ft}$ reference steel tape. The total accuracy of measurements taken with the steel tapes during 1988-90 was estimated to be $0.36 \mathrm{ft}$, neglecting the accuracy of the borehole correction factors (Boucher, 1994a). Accuracy of the borehole correction factors is indeterminate because documentation of the borehole-deviation surveys was inadequate to assess their accuracy, and because no borehole-deviation data are available for wells $\mathrm{J}-11, \mathrm{~J}-12$, and $\mathrm{J}-13$. The unknown accuracy of the borehole corrections poses a problem in the calculation of overall accuracy values.

\section{Hourly Measurements}

Hourly water-level measurements require that equipment be installed in the well to record water levels. Trained personnel install the equipment in the well, periodically calibrate equipment or replace it as necessary, and periodically retrieve the data from the site.

Hourly measurements are of a sufficient frequency that water-level fluctuations are adequately defined to evaluate daily or longer term trends. Hourly measurements are not sufficient, however, to detect short-term waterlevel fluctuations, such as those induced by earthquakes (O'Brien, 1992). Hourly measurements were stored and later retrieved from the data loggers at each site. Continuous measurements were collected at wells USW H-5 and USW H-6 in 1995 to monitor water-level and fluid-pressure response to earthquakes; however, these continuous data are not included in this report.

Pressure transducers and data loggers are used to measure water-level fluctuations. Because of the large depths to water (up to $752 \mathrm{~m}$ ), traditional water-level sensing methods, such as float-cable-pulley system, waterseeking device, and bubble tube, are not feasible. However, electronic signals from a submerged pressure transducer are relatively easy to transmit through a multi-conductor suspension cable to a recording device accessible to personnel on the surface. Electronic data loggers at the surface are used to control, measure, and store data from the pressure transducers.

\section{Equipment}

The hourly water-level network equipment consists of a pressure transducer, which senses depth of submergence, a wireline cable to transmit voltage between the transducer and the surface, and a data logger to control the system, measure the transducer output, and store the data. An external 12-volt battery provides power to the system, and a solar panel charges the battery.

The wireline cable, consisting of four conductors, appropriate insulation, and two external wire wraps (for strength and stability), is used to transmit voltage between the data logger at the surface and the downhole pressure transducer. The required length of wireline cable to monitor a typical well at Yucca Mountain weighs several tens of kilograms, so power equipment is used to install and calibrate the system.

The water-level monitoring systems are calibrated at least every 4 months, and the calibration includes a water-level measurement. The water-level measurements are made using either the transducer, a steel tape, or a multiconductor cable unit. The water-level measurements, after adjustments, result in altitudes of water surface at the time of calibration. 


\section{Transducers}

Water-level fluctuations in the hourly network were measured with pressure transducers and pressure transmitters during 1995. Transducers and transmitters are pressure sensors which convert a change in a mechanical quantity (such as pressure) into a change in an electrical quantity (such as resistance). In this report, the term "transducer" refers to either a depth-measurement pressure transducer or pressure transmitter. These sensors are used to measure pressure and are capable of being immersed in water to measure the depth of submersion. Because the transducer remains at a fixed depth in the well, water-level fluctuations are equivalent to changes in the depth of submersion detected by the transducer.

The pressure-sensing components of a transducer consist of a strain gage to convert pressure into electrical resistance and a Wheatstone bridge to allow measurement of the change in resistance. The major difference between pressure transducers and transmitters is in the form of the input and output. Pressure transducers use voltage as input and output, whereas pressure transmitters use current as input and output. Pressure transmitters are constructed with the same strain gage and Wheatstone bridge arrangement as a pressure transducer; however, the current input is converted to voltage by an amplifier before it enters the strain gage and the voltage is converted back to current by a regulator after it passes through the Wheatstone bridge. The required wiring of pressure transducers and transmitters differs because the data loggers are not capable of measuring current. The output signal of a transmitter must be connected to a resistance load, and the drop in voltage across the load is then measured by the data logger. Regardless of which type of pressure sensor is used, the transducer output increases as the depth of submergence increases.

Transducers are made for a range of pressures. Generally, the smaller the pressure range of the transducer the more accurately pressure changes and water-level fluctuations can be measured. Transducer pressure ranges used in the hourly water-level network were 5 and 20 psi (pounds per square inch); however, the 5 psi range was most commonly used.

The water-level network historically has used both absolute and gage transducers. An absolute transducer measures pressure relative to a fixed reference pressure, whereas a gage transducer measures pressure relative to atmospheric pressure. A gage transducer has a vent tube from the reference side of the strain gage to a point above the water surface. Gage transducers are preferable in the water-level network because only water-level fluctuations (and not air-pressure changes) affect the transducer output, and these were used exclusively in the water-level network during 1995.

As a part of the calibration process, a water-level measurement must be obtained by either a manual measurement, using a steel tape, multiconductor cable, or by "tagging" the water level using the transducer. Tagging the water level, which is the more frequently used method of water-level measurement during calibrations, is done by raising or lowering the transducer until it comes in contact with the water surface in the well. The difference in the depth to water from the last manual measurement, indicated by a tape mark on the transducer cable, is then noted in the log book as part of the calibration record. If the transducer is functioning properly, the water level obtained by tagging should be as accurate as a manual measurement; however, if the transducer is not functioning properly, errors in the measured water level (probably less than $0.1 \mathrm{~m}$ ) are possible.

The transducers are calibrated when installed in the well, when removed from the well (if possible), and at least every 4 months while in service in the well. The calibration consists of manually raising or lowering the transducer in increments and noting the change in transducer output. The data logger (described in the next section) is used in the calibration to provide the applied voltage, if necessary, and to measure the output voltage, so the calibration is for the entire transducer/data-logger system and not only for the transducer.

On January 18, 1995, the transducer/data-logger system at well UE-25 WT\#3 was calibrated. The calibration started with the transducer submerged $1.52 \mathrm{~m}$ below the water surface. The following values were obtained: 


\begin{tabular}{|cc|}
\hline $\begin{array}{c}\text { Depth of submergence } \\
\text { below water surface } \\
\text { (meters) }\end{array}$ & $\begin{array}{c}\text { Average transducer output } \\
\text { (millivolts) }\end{array}$ \\
\hline 1.52 & 27.12 \\
1.22 & 23.69 \\
1.16 & 23.00 \\
1.10 & 22.34 \\
1.04 & 21.67 \\
0.98 & 20.96 \\
0.91 & 20.34 \\
0.85 & 19.62 \\
0.79 & 18.95 \\
0.73 & 18.28 \\
0.67 & 17.60 \\
0.61 & 16.91 \\
0.30 & 13.49 \\
0.00 & 10.10 \\
\hline
\end{tabular}

The transducer output is the average of three readings taken after the transducer output has stabilized. A regression analysis was performed on the calibration data, excluding any points where the transducer was not submerged. The slope of the regression line for well UE-25 WT\#3 on January 18, 1995, was 0.090 meters per millivolt with a coefficient of determination $\left(\mathrm{r}^{2}\right)$ of 1.0. The slope of the regression line, the transducer output at the set point after calibration and before the next calibration, and the water-level measurement at the time of calibration were used to convert transducer output to water-level altitude. The set point is the position below the water surface at which the transducer is placed for water-level monitoring.

\section{Data Loggers}

Data-collection platforms (DCP's) that collect, store, and transmit data to a satellite from which the data are relayed to a ground station, were used as the primary data-acquisition system for the hourly water-level network during 1995. The Campbell Scientific $21 \mathrm{X}$ Micrologger, used in the hourly water-level network as the primary data-acquisition system prior to 1993, is a microprocessor-based system that was used as a supplemental dataacquisition system at selected wells. Details of the $21 \mathrm{X}$ Micrologger operation and programming are described by Luckey and others (1993) and Lobmeyer and others (1995).

A DCP was first installed at well USW G-3 in December 1989, and at all hourly monitored wells by May 1993. Handar model 570A units were the DCP's used to replace the 21X Micrologger system. The DCP has the same functions as a micrologger, but, in addition to internal storage of data, data are transmitted to a Geostationary Operational Environmental Satellite (GOES). Details of DCP use and operation, and GOES systems are described by Blee and others (1986). Data are collected hourly, stored, and transmitted every 4 hours to a GOES satellite. The data are then relayed to a Direct Readout Ground Station (DRGS) and stored in USGS computers for evaluation and further processing.

In addition to transducer output, the data loggers also read information such as battery voltage, excitation voltage, and the panel temperature of the data loggers. These variables are important in evaluation of the reliability of the system and are also transmitted with the transducer data. All internally stored data in the DCP are periodically transferred to computer diskettes using a portable computer. These data files are identified with station ID and time tags and are used as backups to the transmitted data; filling in data gaps that may occur due to any malfunctions in the transmission or receiving process. 


\section{Processing and Adjustments}

The data stored in the data loggers and transferred to computers are not water-level data but rather transducer output, in millivolts. The transducer output are converted to water levels, as explained in the following section, "Conversion to Water-Level Altitude." The water-levels are then evaluated. Anomalous data points, such as those produced during transducer calibrations, by random electronic signals, or due to instrument malfunction are not retained as water levels.

\section{Conversion to Water-Level Altitude}

In an ideal circumstance, a transducer would be calibrated several times during its operating life, its output would be free of drift, and its characteristics would not change with time. However, this ideal situation rarely occurred, causing the transducer output conversion to be more difficult. As a result, some of the transducer output and resulting converted water levels were not considered reliable.

Converted water levels were evaluated for data reliability. The data were examined at a time scale which clearly showed the hourly and daily fluctuations so that the validity of the data could be determined. The data were compared to barometric-pressure data, earth-tide potential data, and other periods of record for the same site and depth interval. If the data were independently validated, the data were retained and included in this report. If the data were not validated independently, the data were given indeterminate status and are not included in this report.

The equation for converting transducer output to water-level altitude under ideal conditions is:

$$
W=W_{c}+\left(T-T_{c}\right) S_{c}
$$

where,

$\mathrm{W}$ is the water-level altitude, in meters;

$\mathrm{W}_{\mathrm{c}}$ is the water-level altitude at calibration, in meters;

$T$ is the transducer output, in millivolts;

$\mathrm{T}_{\mathrm{c}}$ is the transducer output at set point following calibration, in millivolts; and

$\mathrm{S}_{\mathrm{c}}$ is the slope of the regression line, in meters per millivolt.

Equation 4 is from O'Brien and others (1995).

The following example calculation from UE-25 WT\#3 illustrates how transducer data was converted to water levels. The water-level altitude for the calibration on January 18, 1995, was $729.66 \mathrm{~m}$ (based on a tag of the water level with the transducer). The calibration indicated that a $0.090-\mathrm{m}$ change in water level would cause the transducer output to change by approximately 1 millivolt. The transducer output at the post-calibration set point (0.91 m below water surface) was 20.28 millivolts. The transducer output at 15:00:00 on January 20, 1995, was 21.14 millivolts. To summarize, equation 4 variables are:

$$
\begin{aligned}
& \mathrm{W}_{\mathrm{c}}=729.66 \text { meters } \\
& \mathrm{T}=21.14 \text { millivolts } \\
& \mathrm{T}_{\mathrm{c}}=20.28 \text { millivolts } \\
& \mathrm{S}_{\mathrm{c}}=0.090 \text { meters/millivolt }
\end{aligned}
$$

Given these data, the water-level calculation for 15:00:00 on January 20, 1995, would be as follows:

$$
\mathrm{W}=729.66+(21.14-20.28) 0.090=729.74 \text { meters }
$$

Change in the slope of the regression line, $S_{c}$, and change in the transducer output at set point, $T_{c}$, between consecutive calibrations, are types of drift corrected for in the conversion process. Although the slope of the regression line generally does not change dramatically between calibrations, it usually changes to some degree. 
The change in slope is assumed to be linear between calibrations. Set-point drift occurs when the expected transducer output (based on manual tags) does not match the actual measured set-point output. Set-point drift is also assumed to be linear over time.

The water-level altitude is assumed to have remained constant from the last transducer output prior to calibration through the first transducer output after calibration. This assumption probably introduces, at most, a few hundredths of a meter error in the calculation of water-level altitude. If more than one calibration was done on a transducer on the same day, the last calibration is used to calculate water-level altitude for the following period unless the coefficients of determination of the regression lines indicated that another calibration was superior.

\section{Quality-assurance}

Water-level data for Yucca Mountain and vicinity may be used to assess the expected performance of a potential high-level nuclear-waste repository, and confidence in the reliability of the data used in such an assessment is required. A quality-assurance program has been implemented by the U.S. Geological Survey for the Yucca Mountain Project to support the reliability of the data and interpretations of the data.

\section{Onsite Procedures}

The quality-assurance program requires that water-level measurements be obtained by methods described by formal technical procedures. The technical procedures include calibrations and adjustments done during the measuring operation to ensure that the equipment is operating properly and that expected precision and accuracy are attained. For example, the procedure for measuring water-level changes with a pressure transducer specifies how to install and calibrate the transducer, and how to maintain the records of the calibrations.

Data are recorded in logbooks at the well site. Data recorded include: time and date of the visit; names of operators making the visit; identification of specific equipment used; calibration data; water-level measurement data; and correction factors, if any, applied to the data at the well site. In addition, the entry in the logbooks may include comments concerning factors that may be relevant to the collected data, such as discussion of problems with equipment or weather conditions during the water-level measurement or transducer calibration.

\section{Office Processing and Review}

The original logbooks and records are maintained throughout the calendar year at the onsite operations headquarters on the Nevada Test Site. The records are reviewed for completeness and accuracy and to ensure that proper technical procedures were followed. Any needed adjustments not done during onsite operations, such as tape and borehole-deviation corrections, are made in the Denver office. After independent data review and any needed adjustments, the logbooks and related records are transferred to a Yucca Mountain Project archive.

The transducer output is entered into a temporary computer data base and is plotted to facilitate data review and to discover any instrumentation problems. After this review, the transducer output is converted to water levels. The converted water-level data are reviewed for technical quality. In addition to being published by the U.S. Geological Survey, both the raw transducer output and the water-level altitudes are placed in permanent computer data bases, such as the Unit Values file of the NWIS used by the U.S. Geological Survey. Water-level altitudes obtained from manual measurements are also placed in the computer data base.

\section{Qualified and Unqualified data}

Data used by the Yucca Mountain Project are classified as either "qualified" or "unqualified". Qualified data are defined as "data acquired or developed for the Yucca Mountain Project under a Nuclear Regulatory Commission accepted quality assurance plan or qualified in accordance with appropriate Yucca Mountain Project procedures. Developed data cannot be classified as 'Qualified' if derived from unqualified data sources" 
(U.S. Department of Energy, written commun., 1993). An example of "developed" data is a water-level altitude that is calculated from a depth-to-water-measurement, altitude of measuring point, and various correction factors.

Depth-to-water measurements collected at Yucca Mountain after 1989 are obtained in accordance with approved Yucca Mountain Project quality-assurance procedures, and these uncorrected measurements are classified as qualified data. However, measuring point altitudes and data used to calculate correction factors, such as borehole-temperature and borehole-deviation data, were obtained prior to the implementation of the accepted Yucca Mountain Project quality-assurance program in 1989. Therefore, these data and the calculated water-level altitudes presented in this report are classified as unqualified data.

\section{WELL DATA AND WATER LEVELS}

This section contains information and data of all wells monitored as part of the Yucca Mountain Potentiometric Site Studies Project during 1995. Information for each well includes source of information about the well, of which most is published information. Borehole-geophysical logs and core-measurement data for the wells are given by Nelson and others (1991). Previously collected water-level data can be found in Boucher (1994b), Gemmell (1990), Lobmeyer and others (1995), Luckey and others (1993), O'Brien (1991, 1992, and 1993), O'Brien and others (1995), Tucci, O'Brien, and Burkhardt (1996), Tucci, Goemaat, and Burkhardt (1996) and Graves and others (1996). Complete bibliographic citations are in the "References Cited" section. Important information about each well (location and identification, drilling and casing information, access to and description of interval for measuring water levels, and information for calculation of water-level altitude) are summarized in the "Well Specifications" subsection of each well. Although water-level altitudes are corrected for borehole deviation, other depth-related values (such as casing or access-tube depths) in this subsection are uncorrected. Various statistical information concerning the water levels, and hydrographs of water-level altitudes are also presented for each well. Hydrographs are uniformly plotted for calendar year 1995 with a y-axis (water-level) span of $2.5 \mathrm{~m}$.

Additional information included for each well is specific to the frequency of data collection (periodic or hourly measurements). For wells that were measured periodically at any time during the year, a table with the periodic measurement and method of measurement is included. For wells that were measured hourly at any time during the year, two tables are shown, one with the transducer calibration information and the other with the monthly mean water levels for the months the hourly measurements were made. The monthly mean water levels were calculated from available daily mean values. The monthly values were calculated regardless of the number of missing daily mean values. Calibration information includes the transducer serial number, calibration date, slope of the regression line, coefficient of determination, and the water-level altitude determined at the time of calibration. Comments concerning any special conditions or information that might affect the results of the calibrations or conversion of data to water levels are included, as well as explanations for periods of missing water-level data.

The 1995 mean water-level altitude is given and compared to the 1994 mean water-level altitude for each well. For wells monitored hourly during 1995, the mean water level used to compare to the 1994 mean was calculated solely from the hourly data. Because the 1995 mean water level of the hourly data is calculated from daily mean values, and because there is minimal water level change in each well, these mean water levels were not recalculated to include the one or two manual measurements made during the remainder of the year. An exception to this procedure was well USW H-3, lower interval. Because of the significant rising trend of the water level in this well, the 1995 mean was recalculated by averaging the monthly mean water-level altitudes with the October and December manual water-level measurements. For those wells that were only measured periodically, the 1995 mean water-level altitude is calculated from all of the periodic measurements.

In comparing the 1995 and 1994 mean water-level altitudes, there is no distinction made in respect to the frequency of measurements. The comparisons are made to the 1994 values reported in Graves and others (1996), regardless of whether or not the frequency of measurement was the same in 1995 as in 1994. 
Hydrographs of wells monitored periodically are plots of the periodic data. Hydrographs of wells monitored hourly are plots of the daily mean values of the hourly data. Only those hourly values that were evaluated as "valid" were used to calculate the daily mean values. For any day that 6 or more consecutive hours of data were missing, a daily mean value was not calculated. Hydrographs of wells monitored periodically and hourly includes both sets of data. For identification purposes on hydrographs of combined data, the manual periodic data is labeled as "PERIODIC MEASUREMENTS" and the daily mean values are labeled as "HOURLY MEASUREMENTS."

Annual minimum and maximum water-level altitudes are presented for each well. For wells monitored periodically, the range of water-level altitudes is from the periodic measurements. For wells monitored hourly the range of water-level altitudes is from the daily mean values of the hourly data. For wells monitored periodically and hourly, the range of water-level altitudes is from the combined sets of data.

On average, mean 1995 water levels were higher than 1994 mean water levels; however, the average difference was only $0.01 \mathrm{~m}$ higher. Mean water levels ranged from $1.05 \mathrm{~m}$ higher (USW H-3, lower interval) to $0.35 \mathrm{~m}$ lower (USW G-2) than 1994 mean levels. The water-level rise in well USW H-3, lower interval, is anomalously large because the water level in this interval is still equilibrating in response to well reconfiguration in 1990. The water-level drop in well USW G-2 is anomalously large because well USW G-2 was pumped during October and November 1995, and the mean water level only represents data collected during the time the well was pumped. Excluding wells USW H-3, lower interval and USW G-2, the mean water levels ranged from $0.23 \mathrm{~m}$ higher (USW H-1, tube 1) to 0.12 m lower (USW H-1, tube 2) than 1994 mean water levels. The average waterlevel difference of $0.01 \mathrm{~m}$ between 1995 and 1994 mean levels does not include the data for wells USW H-3, lower interval or USW G-2.

\section{Well USW WT-1}

Information about the history of well USW WT-1 and about previous data from the well was obtained from various sources. These sources are: Robison (1984); Robison (U.S. Geological Survey, written commun., 1986); Robison and others (1988); Holmes \& Narver, Inc. (written commun., 1986); and Fenix \& Scisson, Inc. (1986a, 1987c).

Well specifications

1. Location and identification:

Latitude and longitude: $36^{\circ} 49^{\prime} 16^{\prime \prime} \mathrm{N}$.; $116^{\circ} 26^{\prime} 56^{\prime \prime} \mathrm{W}$.

Nevada State Central Zone Coordinates (m): N 229,801; E 171,828.

U.S. Geological Survey Site ID: 364916116265601.

2. Drilling and casing information:

Well started: April 28, 1983.

Well completed: May 18, 1983.

Drilling method: Rotary, using rock bits and air, water, and soap-circulating medium; core obtained from bottom of the borehole.

Bit diameter below water level: $222 \mathrm{~mm}$.

Casing: Surface casing only, to a depth of $9.91 \mathrm{~m}$.

Total drilled depth: $515 \mathrm{~m}$. 
3. Access to and description of depth interval for measuring water levels:

62-mm inside-diameter tubing that has a 3.7-m-long well screen on the bottom; tubing and attached screen extend from land surface to a depth of $507.5 \mathrm{~m}$; saturated interval of the borehole is within the Calico Hills Formation and Bullfrog Tuff of the Crater Flat Group.

4. Information for calculating water-level altitude:

Reference point: Top of metal tag on well casing, altitude 1,201.11 m (surveyed by U.S. Geological Survey, 1984).

Measuring point: Top of access tube, $0.314 \mathrm{~m}$ above reference point.

Depth correction for borehole deviation from vertical: $0.326 \mathrm{~m}$, based on approximate depth to water of $471 \mathrm{~m}$ (1990 data).

Well USW WT-1 was measured hourly and periodically during 1995 . Hourly measurements were made until September 27, 1995; the day the transducer was removed from the well. During the period of hourly measurements, four calibrations of one transducer were performed. In addition, a calibration was completed on September 15, 1994. This calibration was used to calculate water-level altitudes at the beginning of 1995 . Results of the transducer calibrations are as follows:

\begin{tabular}{cccccc}
\hline $\begin{array}{c}\text { Transducer serial } \\
\text { number }\end{array}$ & $\begin{array}{c}\text { Calibration } \\
\text { date }\end{array}$ & $\begin{array}{c}\text { Slope } \\
\text { (meters/ } \\
\text { millivolt) }\end{array}$ & $\begin{array}{c}\text { Coefficient of } \\
\text { determination }\end{array}$ & $\begin{array}{c}\text { Water-level } \\
\text { altitude } \\
\text { (meters) }\end{array}$ & $\begin{array}{c}\text { Method of measuring } \\
\text { water level }\end{array}$ \\
\hline 567097 & $09-15-94$ & 0.089 & 1.00 & 730.29 & Tag with transducer \\
567097 & $01-18-95$ & .089 & 1.00 & 730.28 & Tag with transducer \\
567097 & $05-24-95$ & .089 & 1.00 & 730.28 & Chain \#3 \\
567097 & $08-31-95$ & .091 & 0.99 & 730.25 & Tag with transducer \\
567097 & $09-27-95$ & .091 & 1.00 & 730.33 & Chain \#3 \\
\hline
\end{tabular}

All transducer data collected for USW WT-1 for 1995 were considered to be valid. There was no lost record during the period of instrumentation.

Following the removal of the transducer, well USW WT-1 was measured periodically during the remainder of 1995. Measurements were made with Chain $\# 3$ with the following results:

\begin{tabular}{ccc}
\hline Date & $\begin{array}{c}\text { Measured water-level altitude } \\
\text { (meters, above sea level) }\end{array}$ & Method of measuring water level \\
\hline $09-27-95$ & 730.33 & Chain \#3 \\
$12-12-95$ & 730.35 & Chain \#3 \\
\hline
\end{tabular}

Daily mean water-level altitudes of the hourly data for well USW WT-1 ranged from 730.21 to $730.43 \mathrm{~m}$ above sea level in 1995 (fig. 2). Monthly mean water-level altitudes for January through September 1995, are listed in table 6. The mean water-level altitude of the 1995 hourly data was $730.31 \mathrm{~m}$ above sea level. This mean altitude was $0.02 \mathrm{~m}$ lower than the mean altitude of $730.33 \mathrm{~m}$ for 1994 (Graves and others, 1996). 


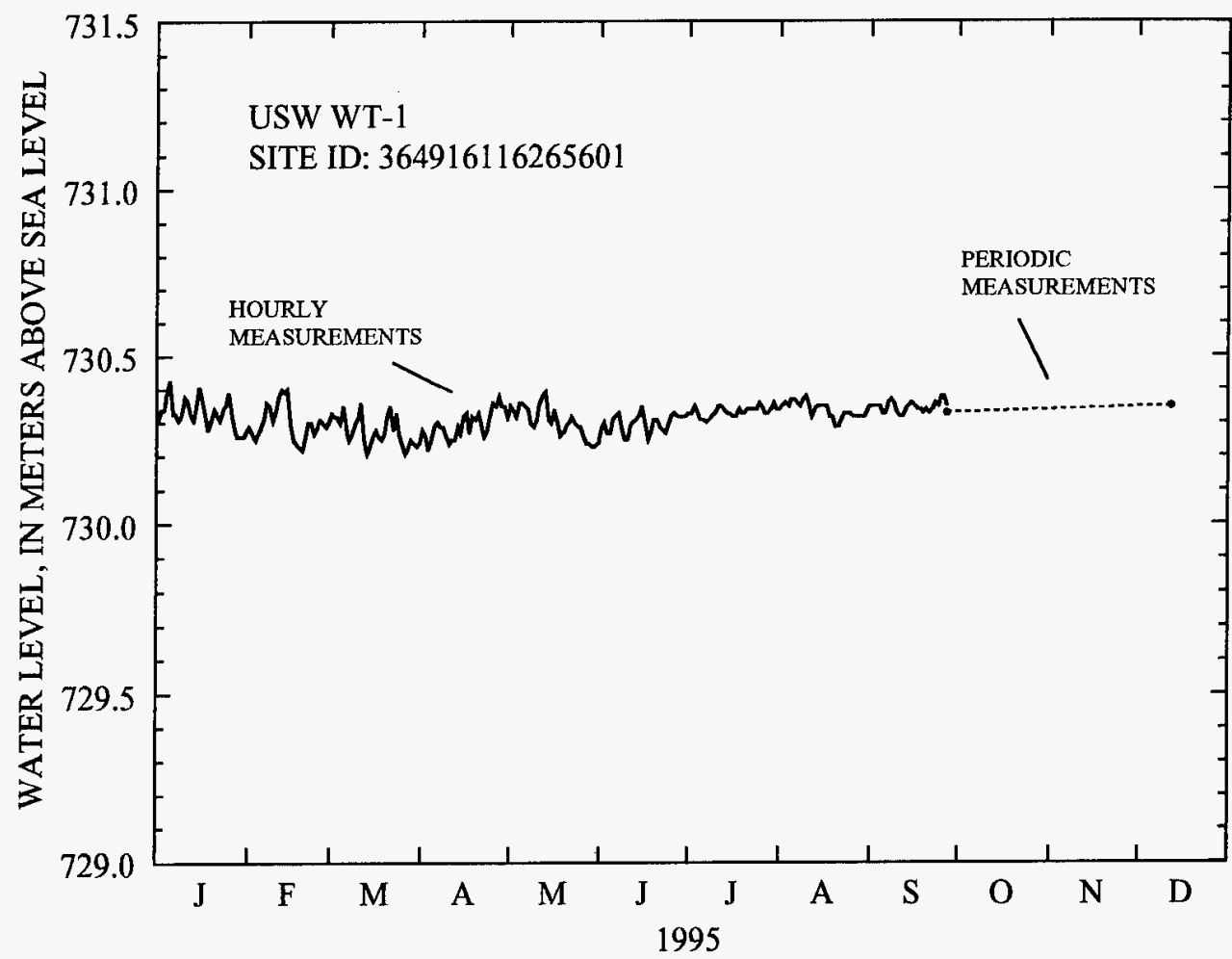

Figure 2. Water-level altitudes, 1995, for well USW WT-1.

Table 6. Monthly mean water-level altitudes, 1995, for well USW WT-1.

[Monthly means were calculated regardless of the number of missing data. Daily means were not calculated if 6 or more consecutive hours of data were missing; --, data not available; NA, not applicable, well not instrumented during this month]

\begin{tabular}{lcc}
\hline Month & $\begin{array}{c}\text { Monthly mean } \\
\text { water-level altitude } \\
\text { (meters, above sea level) }\end{array}$ & $\begin{array}{c}\text { Number of missing daily } \\
\text { means }\end{array}$ \\
\hline January & 730.33 & 0 \\
February & 730.30 & 0 \\
March & 730.28 & 0 \\
April & 730.30 & 0 \\
May & 730.31 & 0 \\
June & 730.30 & 0 \\
July & 730.33 & 0 \\
August & 730.34 & 0 \\
September & 730.35 & 0 \\
October & -- & NA \\
November & -- & NA \\
December & -- & NA \\
\hline
\end{tabular}




\section{Well USW WT-2}

Information about the history of well USW WT-2 and about previous data from the well was obtained from various sources. These sources are: Robison (1984); Robison (U.S. Geological Survey, written commun., 1986); Robison and others (1988); and Fenix \& Scisson, Inc. (1986a, 1987c).

Well specifications

1. Location and identification:

Latitude and longitude: $36^{\circ} 50^{\prime} 23^{\prime \prime N}$.; $116^{\circ} 27^{\prime} 18^{\prime \prime} \mathrm{W}$.

Nevada State Central Zone Coordinates (m): N 231,849; E 171,274.

U.S. Geological Survey Site ID: 365023116271801.

2. Drilling and casing information:

Well started: July 8, 1983.

Well completed: July 16, 1983.

Drilling method: Rotary, using rock bits and air-foam circulating medium; core obtained from bottom of the borehole.

Bit diameter below water level: $222 \mathrm{~mm}$.

Casing: Surface casing only, to a depth of $18 \mathrm{~m}$.

Total drilled depth: $628 \mathrm{~m}$.

3. Access to and description of depth interval for measuring water levels:

62-mm inside-diameter access tubing that has a 3.6-m-long well screen on bottom, extending from land surface to a depth of $622 \mathrm{~m}$; saturated interval of the borehole is within the Prow Pass Tuff of the Crater Flat Group.

4. Information for calculating water-level altitude:

Reference point: Top of metal tag on well casing; altitude 1,301.13 m (surveyed by U.S. Geological Survey, 1984).

Measuring point: Top of access tube, $0.305 \mathrm{~m}$ above reference point after 12/08/93, $0.146 \mathrm{~m}$ above reference point between $9 / 09 / 93$ and $12 / 08 / 93$, and $0.311 \mathrm{~m}$ above reference point prior to $9 / 09 / 93$.

Depth correction for borehole deviation from vertical: $0.445 \mathrm{~m}$ after $12 / 08 / 93$ and $0.533 \mathrm{~m}$ prior to $12 / 08 / 93$, based on approximate depth to water of $571 \mathrm{~m}$. 
Well USW WT-2 was measured periodically during 1995 . Measurements were made with the 2,800 foot reference steel tape and Chain \#3 with the following results:

\begin{tabular}{ccl}
\hline Date & $\begin{array}{c}\text { Measured water-level altitude } \\
\text { (meters, above sea level) }\end{array}$ & \multicolumn{1}{c}{ Method of measuring water level } \\
\hline $01-10-95$ & 730.63 & 2,800 foot reference steel tape \\
$03-02-95$ & 730.58 & Chain \#3 \\
$03-24-95$ & 730.59 & Chain \#3 \\
$04-10-95$ & 730.53 & Chain \#3 \\
$05-04-95$ & 730.62 & Chain \#3 \\
$06-13-95$ & 730.51 & Chain \#3 \\
$08-16-95$ & 730.54 & Chain \#3 \\
$09-06-95$ & 730.54 & 2,800 foot reference steel tape \\
$12-12-95$ & 730.62 & Chain \#3 \\
\hline
\end{tabular}

Water-level altitudes for well USW WT-2 ranged from 730.51 to $730.63 \mathrm{~m}$ above sea level in 1995 (fig. 3). The mean water-level altitude of the 1995 periodic data was $730.57 \mathrm{~m}$ above sea level. This mean altitude was $0.04 \mathrm{~m}$ higher than the mean altitude of $730.53 \mathrm{~m}$ for 1994 (Graves and others, 1996).

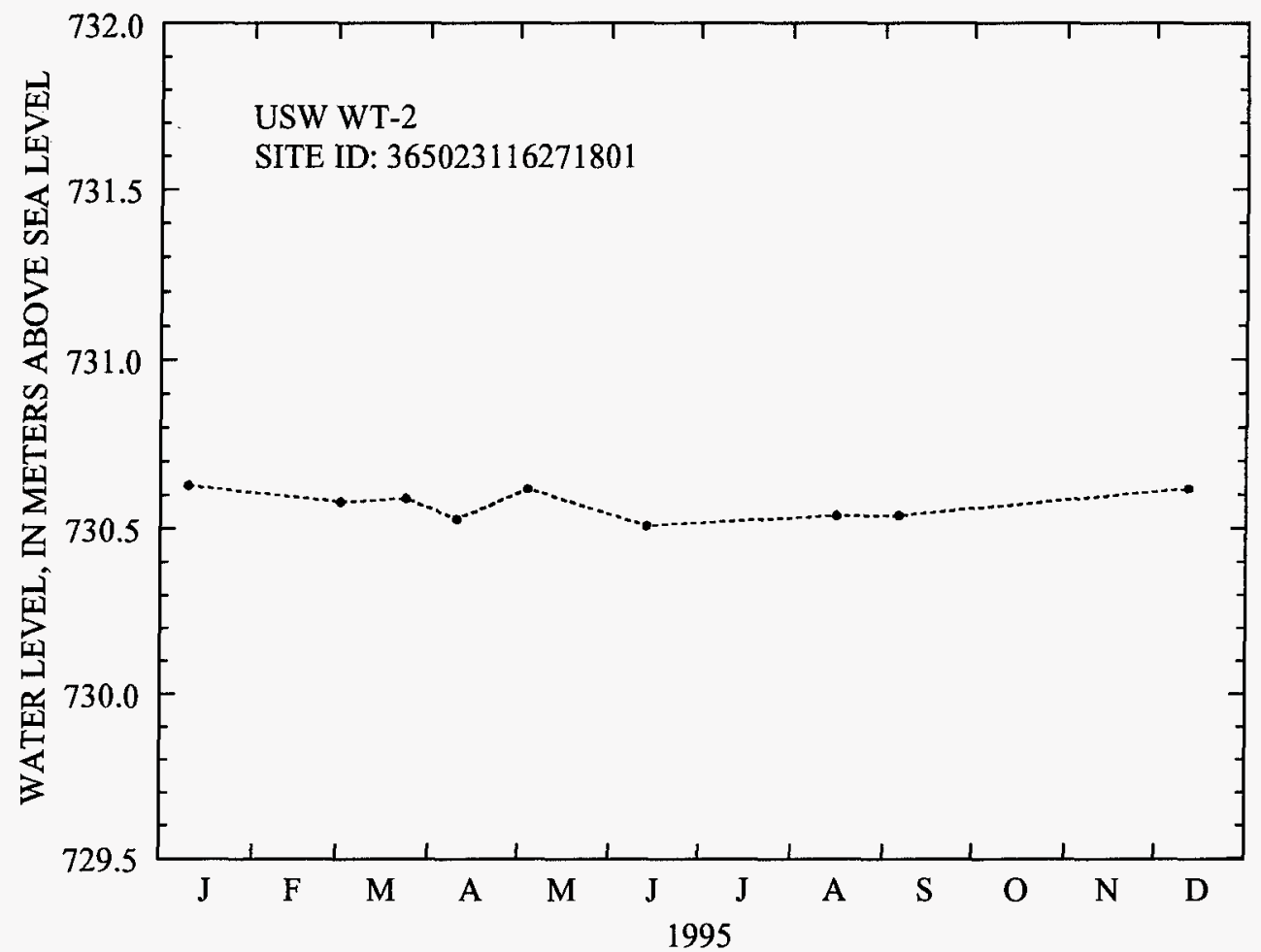

Figure 3. Water-level altitudes, 1995, for well USW WT-2. 


\section{Well UE-25 WT\#3}

Information about the history of well UE-25 WT\#3 and about previous data from the well was obtained from various sources. These sources are: Robison (1984); Robison (U.S. Geological Survey, written commun., 1986); Robison and others (1988); and Fenix \& Scisson, Inc. (1986a, 1987c).

Well specifications

1. Location and identification:

Latitude and longitude: $36^{\circ} 47^{\prime} 57^{\prime \prime} \mathrm{N} . ; 116^{\circ} 24^{\prime} 58^{\prime \prime} \mathrm{W}$.

Nevada State Central Zone Coordinates (m): N 227,379; E 174,768.

U.S. Geological Survey Site ID: 364757116245801.

2. Drilling and casing information:

Well started: April 29, 1983.

Well completed: May 25, 1983.

Drilling method: Rotary, using rock bits and air-foam circulating medium; core obtained from bottom of the borehole.

Bit diameter below water level: $222 \mathrm{~mm}$.

Casing: Surface casing only, to a depth of $12 \mathrm{~m}$.

Total drilled depth: $348 \mathrm{~m}$.

3. Access to and description of depth interval for measuring water levels:

62-mm inside-diameter tubing that has a 3.6-m-long well screen on bottom, extending from land surface to a depth of $343 \mathrm{~m}$; saturated interval of the borehole is within the Bullfrog Tuff of the Crater Flat Group.

4. Information for calculating water-level altitude:

Reference point: Top of metal tag on well casing; altitude 1,030.11 m (surveyed by U.S. Geological Survey, 1984).

Measuring point: Top of access tubing, $0.155 \mathrm{~m}$ above reference point.

Depth correction for borehole deviation from vertical: $0.271 \mathrm{~m}$, based on approximate depth to water of $300 \mathrm{~m}$ (1990 data).

Well UE-25 WT\#3 was measured hourly and periodically during 1995 . Hourly measurements were made until September 26, 1995, the day the transducer was removed from the well. During the period of hourly measurements, four calibrations of one transducer were performed. In addition, a calibration was completed on September 19, 1994. This calibration was used to calculate water-level altitudes at the beginning of 1995 . Results of the transducer calibrations are as follows:

\begin{tabular}{cccccc}
\hline $\begin{array}{c}\text { Transducer serial } \\
\text { number }\end{array}$ & $\begin{array}{c}\text { Calibration } \\
\text { date }\end{array}$ & $\begin{array}{c}\text { Slope } \\
\text { (meters/ } \\
\text { millivolt) }\end{array}$ & $\begin{array}{c}\text { Coefflcient of } \\
\text { determination }\end{array}$ & $\begin{array}{c}\text { Water-level } \\
\text { altitude } \\
\text { (meters) }\end{array}$ & $\begin{array}{c}\text { Method of measuring } \\
\text { water level }\end{array}$ \\
\hline 621313 & $09-19-94$ & 0.090 & 1.00 & 729.66 & Chain \#3 \\
621313 & $01-18-95$ & .090 & 1.00 & 729.66 & Tag with transducer \\
621313 & $05-11-95$ & .090 & 1.00 & 729.78 & Tag with transducer \\
621313 & $06-27-95$ & .090 & 1.00 & 729.66 & Tag with transducer \\
621313 & $09-26-95$ & .090 & 1.00 & 729.75 & Chain \#3 \\
\hline
\end{tabular}


Although the transducer was removed from well UE-25 WT\#3 on September 26, 1995, the transducer data were only converted through part of September 25, 1995. A series of spikes were removed from the transducer data on June 27,1995, the spikes were due to the calibration of the transducer on the same date. Because of the deleted data, a daily mean was not calculated for June 27, 1995. All other transducer data for 1995 were considered to be valid.

Following the removal of the transducer, well UE-25 WT\#3 was measured periodically during the remainder of 1995. Measurements were made with Chain \#3 with the following results:

\begin{tabular}{ccc}
\hline Date & $\begin{array}{c}\text { Measured water-level altitude } \\
\text { (meters, above sea level) }\end{array}$ & Method of measuring water level \\
\hline $09-26-95$ & 729.75 & Chain \#3 \\
$12-12-95$ & 729.76 & Chain \#3 \\
\hline
\end{tabular}

Daily mean water-level altitudes of the hourly data for well UE-25 WT\#3 ranged from 729.63 to $729.80 \mathrm{~m}$ above sea level in 1995 (fig. 4). Monthly mean water-level altitudes for January through September are listed in table 7. The mean water-level altitude of the 1995 hourly data was $729.71 \mathrm{~m}$ above sea level. This mean altitude was $0.01 \mathrm{~m}$ higher than the mean altitude of $729.70 \mathrm{~m}$ for 1994 (Graves and others, 1996).

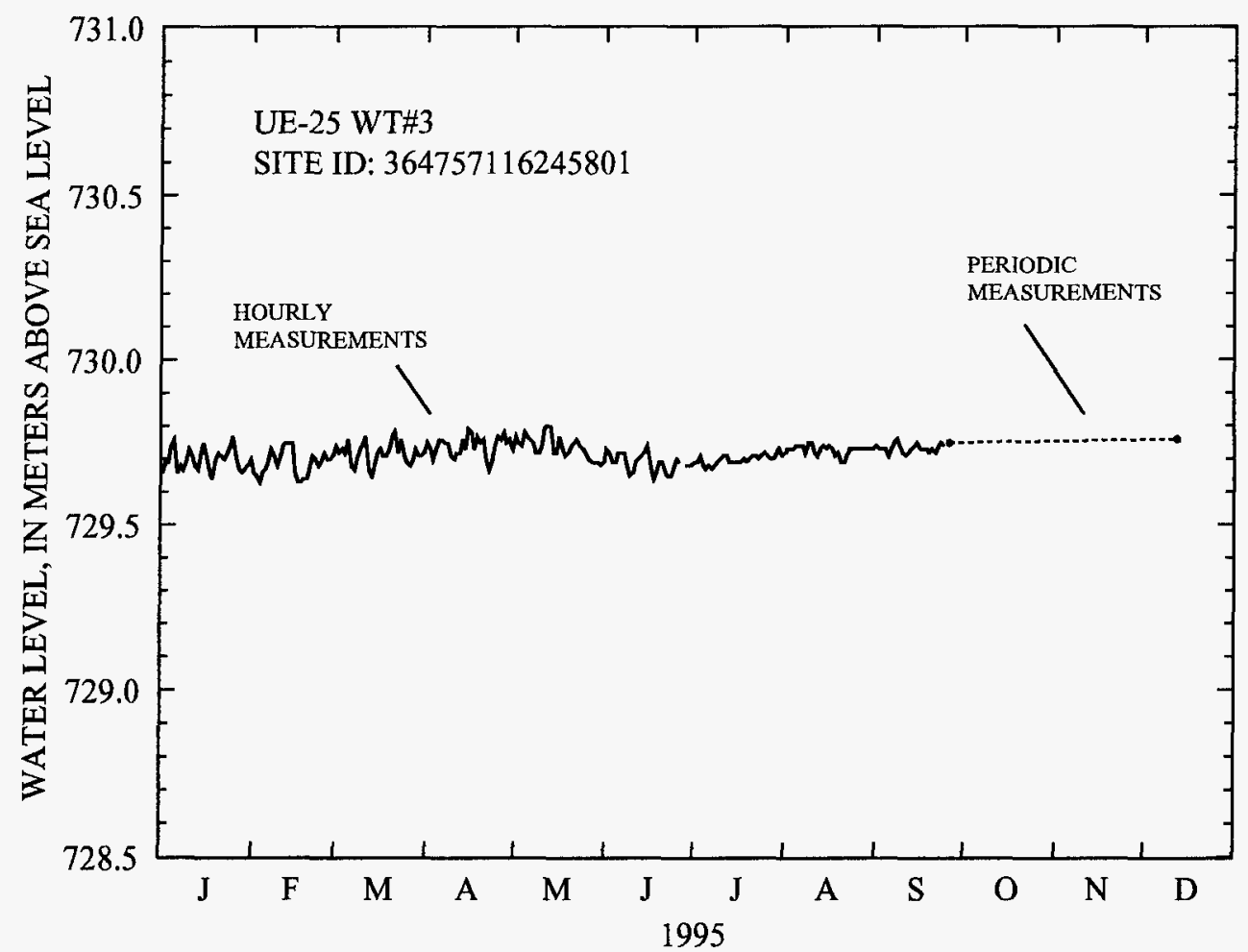

Figure 4. Water-level altitudes, 1995, for well UE-25 WT\#3. 
Table 7. Monthly mean water-level altitudes, 1995, for well UE-25 WT\#3.

[Monthly means were calculated regardless of the number of missing data. Daily means were not calculated if 6 or more consecutive hours of data were missing; --, data not available; NA, not applicable, well not instrumented during this month]

\begin{tabular}{lcc}
\hline Month & $\begin{array}{c}\text { Monthly mean } \\
\text { water-level altitude } \\
\text { (meters, above sea level) }\end{array}$ & $\begin{array}{c}\text { Number of missing daily } \\
\text { means }\end{array}$ \\
\hline January & 729.70 & 0 \\
February & 729.69 & 0 \\
March & 729.72 & 0 \\
April & 729.74 & 0 \\
May & 729.74 & 0 \\
June & 729.69 & 1 \\
July & 729.70 & 0 \\
August & 729.73 & 0 \\
September & 729.73 & 0 \\
October & -- & NA \\
November & -- & NA \\
December & -- & NA \\
\hline
\end{tabular}

\section{Well UE-25 WT\#4}

Information about the history of well UE-25 WT\#4 and about previous data from the well was obtained from various sources. These sources are: Robison (1984); Robison (U.S. Geological Survey, written commun., 1986); Robison and others (1988); Holmes \& Narver, Inc. (written commun., 1986); and Fenix \& Scisson, Inc. (1986a, 1987c).

Well specifications

1. Location and identification:

Latitude and longitude: $36^{\circ} 51^{\prime} 40^{\prime \prime} \mathrm{N}$.; $116^{\circ} 26^{\prime} 03^{\prime \prime} \mathrm{W}$.

Nevada State Central Zone Coordinates (m): N 234,242; E 173,139.

U.S. Geological Survey Site ID: 365140116260301.

2. Drilling and casing information:

Well started: May 28, 1983.

Well completed: June 6, 1983.

Drilling method: Rotary, using rock bits and air-foam circulating medium; Core obtained from bottom of the borehole.

Bit diameter below water level: $222 \mathrm{~mm}$.

Casing: Surface casing only, to a depth of $14.6 \mathrm{~m}$.

Total drilled depth: $482 \mathrm{~m}$. 
3. Access to and description of depth interval for measuring water levels:

62-mm inside-diameter tubing that has a 3.7-m-long well screen on the bottom; tubing and attached screen extend from land surface to a depth of $477.6 \mathrm{~m}$; saturated interval of the borehole is within the Calico Hills Formation.

4. Information for calculating water-level altitude:

Reference point: Top of metal tag on well casing, altitude 1,169.21 m (surveyed by U.S. Geological Survey, 1984).

Measuring point: Top of access tube, $0.311 \mathrm{~m}$ above reference point.

Depth correction for borehole deviation from vertical: $0.454 \mathrm{~m}$, based on approximate depth to water of $438 \mathrm{~m}$ (1990 data).

Well UE-25 WT\#4 was measured hourly and periodically during 1995 . Hourly measurements were made through September 26, 1995, the day the transducer was removed from the well. During the period of hourly measurements, three calibrations of one transducer were performed. In addition, a calibration was completed on December 21, 1994. This calibration was used to calibrate water-level altitudes at the beginning of 1995 . Results of the transducer calibrations are as follows:

\begin{tabular}{cccccc}
\hline $\begin{array}{c}\text { Transducer serial } \\
\text { number }\end{array}$ & $\begin{array}{c}\text { Calibration } \\
\text { date }\end{array}$ & $\begin{array}{c}\text { Slope } \\
\text { (meters/ } \\
\text { millivolt) }\end{array}$ & $\begin{array}{c}\text { Coefficient of } \\
\text { determination }\end{array}$ & $\begin{array}{c}\text { Water-level } \\
\text { altitude } \\
\text { (meters) }\end{array}$ & $\begin{array}{c}\text { Method of measuring } \\
\text { water level }\end{array}$ \\
\hline 592472 & $12-21-94$ & 0.087 & 1.00 & 730.77 & Tag with transducer \\
592472 & $04-06-95$ & .087 & 1.00 & 730.86 & Chain \#3 \\
592472 & $07-13-95$ & .087 & 1.00 & 730.81 & Tag with transducer \\
592472 & $09-26-95$ & .088 & 1.00 & 730.83 & Chain \#3 \\
\hline
\end{tabular}

Spikes were removed from the transducer data on April 5 through 10, 1995. The spikes were due to a weak battery that was not holding its charge. The battery was replaced on April 10,1995. Because of the amount of missing data following the deletion of the spikes, daily mean values were not calculated for these dates. Partial data were recorded for June 27, 1995; the reason for the partial data is not known. A daily mean value was not calculated for this date. All other hourly transducer data for 1995 are considered to be valid.

Following the removal of the transducer, well UE-25 WT\#4 was measured periodically during the remainder of 1995 . Measurements were made with Chain \#3 with the following results:

\begin{tabular}{ccc}
\hline Date & $\begin{array}{c}\text { Measured water-level altitude } \\
\text { (meters, above sea level) }\end{array}$ & $\begin{array}{c}\text { Method of measuring water } \\
\text { level }\end{array}$ \\
\hline $09-26-95$ & 730.83 & Chain \#3 \\
$12-05-95$ & 730.83 & Chain \#3 \\
\hline
\end{tabular}

Daily mean water-level altitudes of the hourly data for well UE-25 WT\#4 ranged from 730.71 to $730.92 \mathrm{~m}$ above sea level in 1995 (fig. 5). Monthly mean water-level altitudes for January through September 1995, are listed in table 8 . The mean water-level altitude of the 1995 hourly data was $730.80 \mathrm{~m}$ above sea level. This mean altitude was $0.02 \mathrm{~m}$ higher than the mean altitude of $730.78 \mathrm{~m}$ for 1994 (Graves and others, 1996). 


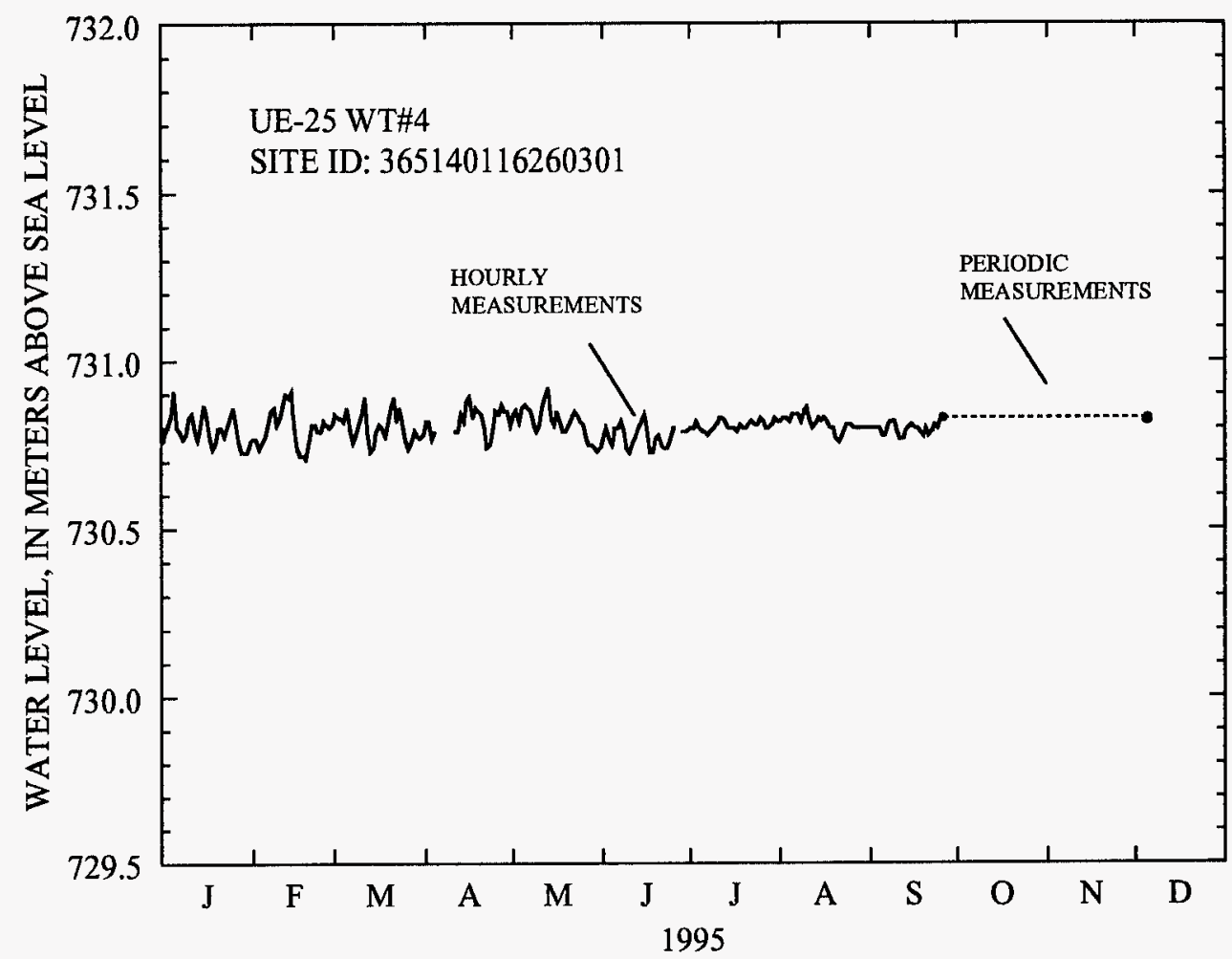

Figure 5. Water-level altitudes, 1995, for well UE-25 WT\#4.

Table 8. Monthly mean water-level altitudes, 1995, for well UE-25 WT\#4.

[Monthly means were calculated regardless of the number of missing data. Daily means were not calculated if 6 or more consecutive hours of data were missing; --, data not available; NA, not applicable, well not instrumented during this month]

\begin{tabular}{lcc}
\hline Month & $\begin{array}{c}\text { Monthly mean } \\
\text { water-level altitude } \\
\text { (meters, above sea level) }\end{array}$ & $\begin{array}{c}\text { Number of missing daily } \\
\text { means }\end{array}$ \\
\hline January & 730.80 & 0 \\
February & 730.80 & 0 \\
March & 730.80 & 0 \\
April & 730.82 & 6 \\
May & 730.82 & 0 \\
June & 730.78 & 1 \\
July & 730.81 & 0 \\
August & 730.81 & 0 \\
September & 730.80 & 0 \\
October & -- & NA \\
November & -- & NA \\
December & -- & NA \\
\hline
\end{tabular}




\section{Well UE-25 WT\#6}

Information about the history of well UE-25 WT\#6 and about previous data from the well was obtained from various sources. These sources are: Robison (1984); Robison (U.S. Geological Survey, written commun., 1986); Robison and others (1988); and Fenix \& Scisson, Inc. (1986a, 1987c).

Well specifications

1. Location and identification:

Latitude and longitude: $36^{\circ} 53^{\prime} 40^{\prime \prime} \mathrm{N}$;; $116^{\circ} 26^{\prime} 46^{\prime \prime} \mathrm{W}$.

Nevada State Central Zone Coordinates (m): N 237,920; E 172,067.

U.S. Geological Survey Site ID: 365340116264601.

2. Drilling and casing information:

Well started: June 20,1983.

Well completed: June 29, 1983.

Drilling method: Rotary, using rock bits and air-foam circulating medium; core obtained from bottom of the borehole.

Bit diameter below water level: $171 \mathrm{~mm}$.

Casing: Surface casing only, to a depth of $76.5 \mathrm{~m}$.

Total drilled depth: $383 \mathrm{~m}$.

3. Access to and description of depth interval for measuring water levels:

62-mm inside-diameter tubing that has a 3.6- $\mathrm{m}$-long well screen on bottom, extending from land surface to a depth of $372 \mathrm{~m}$; saturated interval of the borehole is within the Calico Hills Formation.

4. Information for calculating water-level altitude:

Reference point: Top of metal tag on well casing; altitude 1,314.78 m (surveyed by U.S. Geological Survey, 1984).

Measuring point: Top of access tube, $0.463 \mathrm{~m}$ above reference point.

Depth correction for borehole deviation from vertical: $0.204 \mathrm{~m}$, based on approximate depth to water of $280 \mathrm{~m}$ (1990 data).

Well UE-25 WT\#6 was measured periodically during 1995. Measurements were made with Chain \#3, Chain $\# 4$, and the 2,800 foot reference steel tape with the following results:

\begin{tabular}{rcc}
\hline Date & $\begin{array}{c}\text { Measured water-level altitude } \\
\text { (meters, above sea level) }\end{array}$ & $\begin{array}{c}\text { Method of measuring } \\
\text { water-level }\end{array}$ \\
\hline $01-30-95$ & $1,034.35$ & Chain \#4 \\
$02-23-95$ & $1,034.42$ & Chain \#4 \\
$03-22-95$ & $1,034.42$ & Chain \#3 \\
$04-13-95$ & $1,034.48$ & Chain \#3 \\
$05-09-95$ & $1,034.45$ & Chain \#3 \\
$06-20-95$ & $1,034.59$ & Chain \#3 \\
$07-24-95$ & $1,034.54$ & Chain \#3 \\
$08-01-95$ & $1,034.54$ & 2,800 foot reference steel tape \\
$09-05-95$ & $1,034.54$ & Chain \#4 \\
$12-04-95$ & 1.034 .52 & Chain \#3 \\
\hline
\end{tabular}


Water-level altitudes for well UE-25 WT\#6 ranged from 1,034.35 to $1,034.59 \mathrm{~m}$ above sea level in 1995 (fig. 6). The mean water-level altitude of the 1995 periodic data was $1,034.48 \mathrm{~m}$ above sea level. This mean altitude was $0.01 \mathrm{~m}$ lower than the mean altitude of $1,034.49 \mathrm{~m}$ for 1994 (Graves and others, 1996).

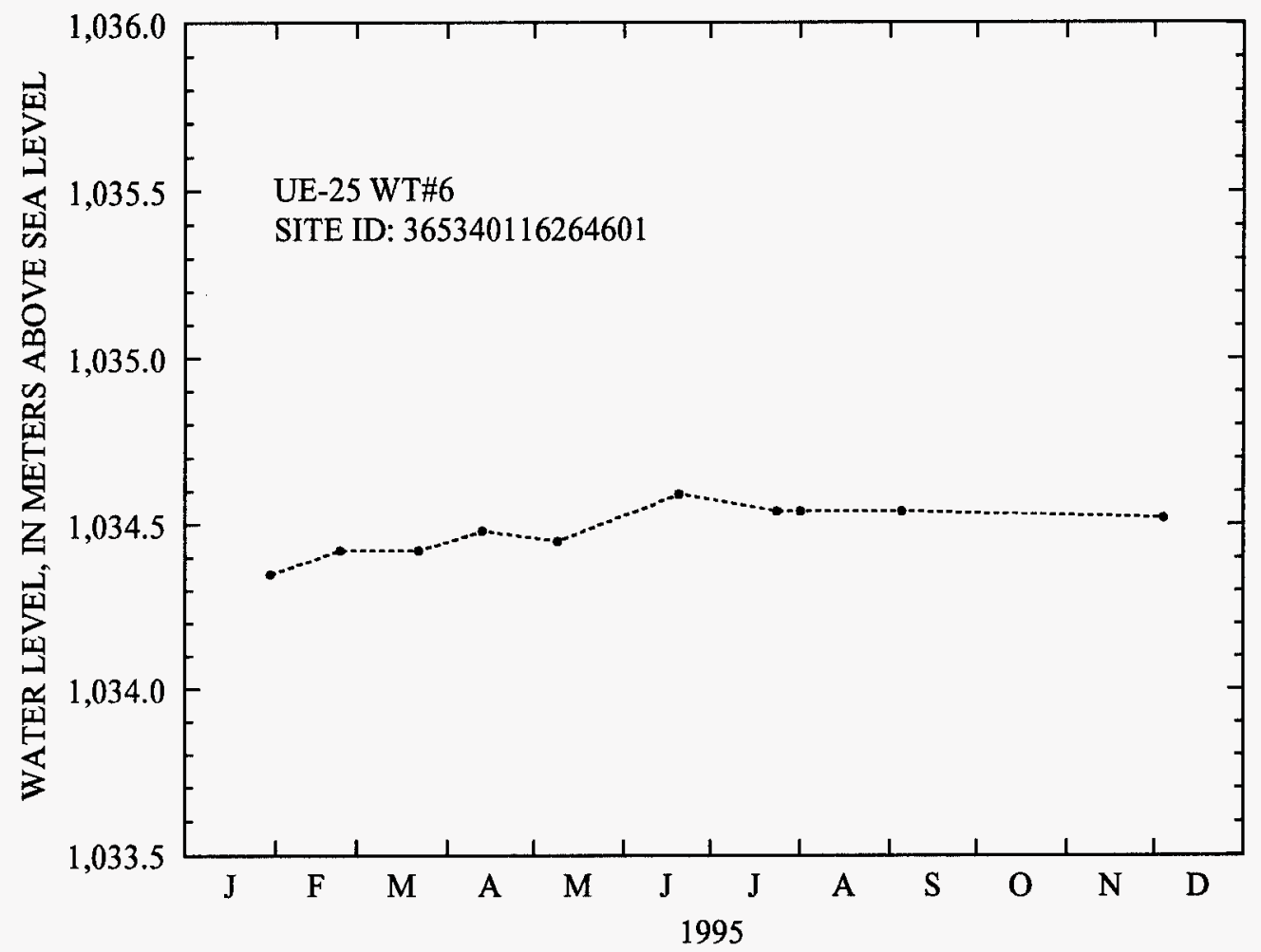

Figure 6. Water-level altitudes, 1995, for well UE-25 WT\#6.

\section{Well USW WT-7}

Information about the history or well USW WT-7 and about previous data from the well was obtained from various sources. These sources are: Robison (1984); Robison (U.S. Geological Survey, written commun., 1986); Robison and others (1988); Holmes \& Narver, Inc. (written commun., 1986); and Fenix \& Scisson, Inc. (1986a, 1987c).

Well specifications

1. Location and identification:

Latitude and longitude: $36^{\circ} 49^{\prime} 33^{\prime \prime N}$.; $116^{\circ} 28^{\prime} 57^{\prime \prime} \mathrm{W}$.

Nevada State Central Zone Coordinates (m): N 230,298; E 168,826.

U.S. Geological Survey Site ID: 364933116285701.

2. Drilling and casing information:

Well started: July 19, 1983.

Well completed: July 26, 1983. 
Drilling method: Rotary, using rock bits and air-foam circulating medium; core obtained from bottom of the borehole.

Bit diameter below water level: $222 \mathrm{~mm}$.

Casing: Surface casing only, to a depth of $15.8 \mathrm{~m}$.

Total drilled depth: $491 \mathrm{~m}$.

3. Access to and description of depth interval for measuring water levels:

62-mm inside-diameter tubing that has a 3.7-m-long well screen on the bottom; tubing and attached screen extend from land surface to a depth of $481.3 \mathrm{~m}$; saturated interval of the borehole is within the Topopah Spring Tuff of the Paintbrush Group and the Prow Pass Tuff of the Crater Flat Group.

4. Information for calculating water-level altitude:

Reference point: Top of metal tag on well casing, altitude $1,196.88 \mathrm{~m}$ (surveyed by U.S. Geological Survey, 1984).

Measuring point: Top of access tube, $0.302 \mathrm{~m}$ above reference point.

Depth correction for borehole deviation from vertical: $0.034 \mathrm{~m}$, based on approximate depth to water of $421 \mathrm{~m}$ (1990 data).

Well USW WT-7 was measured periodically during 1995. Measurements were made with Chain \#3, Chain $\# 4$, and the 2,800 foot reference steel tape with the following results:

\begin{tabular}{rcc}
\hline Date & $\begin{array}{c}\text { Measured water-level altitude } \\
\text { (meters, above sea level) }\end{array}$ & $\begin{array}{c}\text { Method of measuring } \\
\text { water level }\end{array}$ \\
\hline $01-17-95$ & 775.87 & Chain \#4 \\
$02-21-95$ & 775.94 & Chain \#4 \\
$03-28-95$ & 775.98 & 2,800 foot reference steel tape \\
$04-19-95$ & 775.94 & Chain \#3 \\
$05-17-95$ & 775.95 & Chain \#3 \\
$06-22-95$ & 775.88 & Chain \#3 \\
$07-19-95$ & 775.94 & Chain \#3 \\
$08-29-95$ & 775.94 & Chain \#3 \\
$12-06-95$ & 775.95 & Chain \#3 \\
\hline
\end{tabular}

Water-level altitudes for well USW WT-7 ranged from 775.87 to $775.98 \mathrm{~m}$ above sea level in 1995 (fig. 7). The mean water-level altitude of the 1995 periodic data was $775.93 \mathrm{~m}$ above sea level. This mean altitude was $0.05 \mathrm{~m}$ higher than the mean altitude of $775.88 \mathrm{~m}$ for 1994 (Graves and others, 1996). 


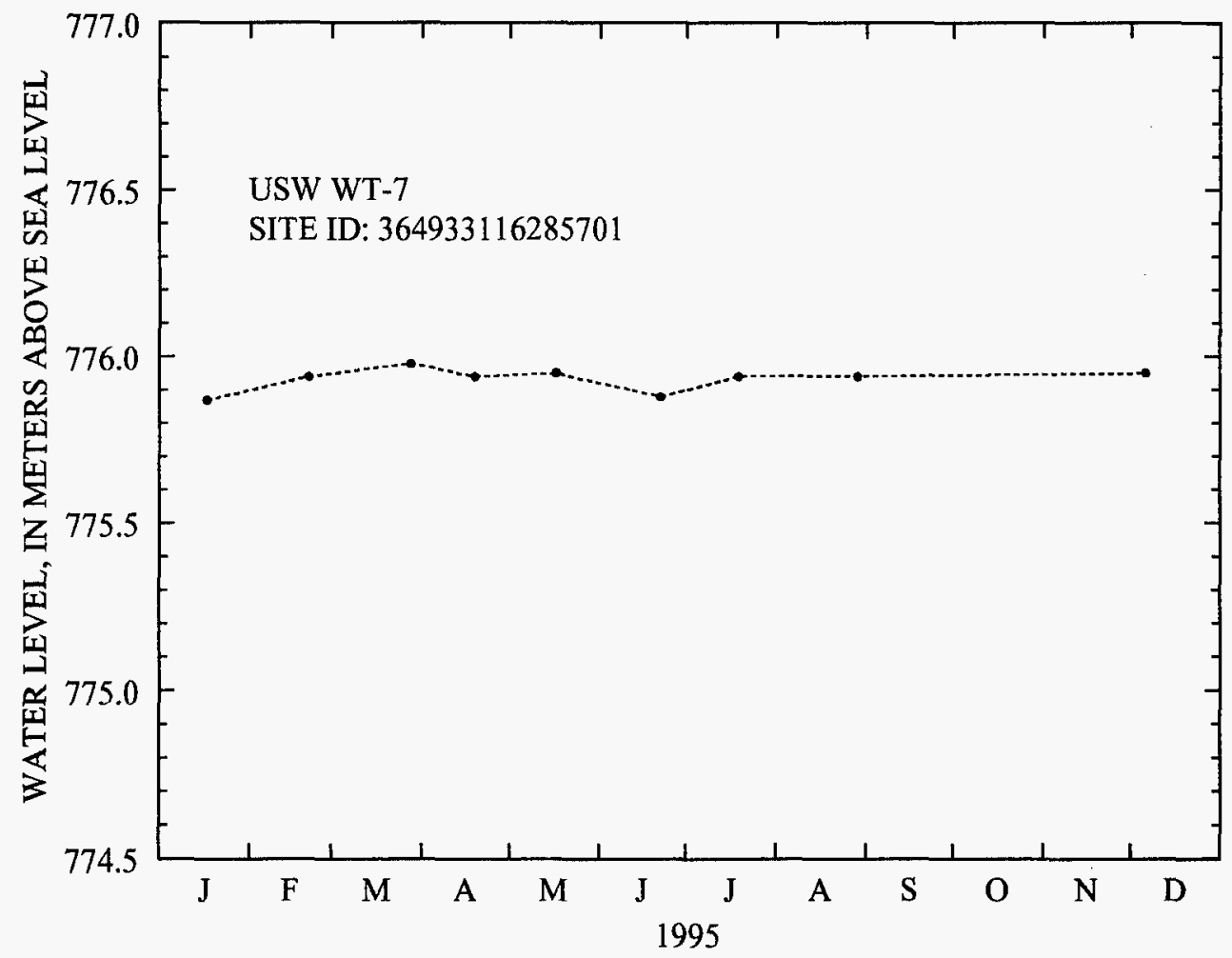

Figure 7. Water-level altitudes, 1995, for well USW WT-7.

\section{Well USW WT-10}

Information about the history of well USW WT-10 and about previous data from the well was obtained from various sources. These sources are: Robison (1984); Robison (U.S. Geological Survey, written commun., 1986); Robison and others (1988); Holmes \& Narver, Inc. (written commun., 1986); and Fenix \& Scisson, Inc. (1986a, 1987c).

Well specifications

1. Location and identification:

Latitude and longitude: $36^{\circ} 48^{\prime} 25^{\prime \prime} \mathrm{N}$.; $116^{\circ} 29^{\prime} 05^{\prime \prime} \mathrm{W}$.

Nevada State Central Zone Coordinates (m): N 228,225; E 168,646.

U.S. Geological Survey Site ID: 364825116290501.

2. Drilling and casing information:

Well started: July 26, 1983.

Well completed: August 2, 1983.

Drilling method: Rotary, using rock bits and air-foam circulating medium; core obtained from bottom of the borehole. 
Bit diameter below water level: $222 \mathrm{~mm}$.

Casing: Surface casing only, to a depth of $34.7 \mathrm{~m}$.

Total drilled depth: $431 \mathrm{~m}$.

3. Access to and description of depth interval for measuring water levels:

62-mm inside-diameter tubing that has a 3.7-m-long well screen on the bottom; tubing and attached screen extend from land surface to a depth of $402.6 \mathrm{~m}$; saturated interval of the borehole is within the Topopah Spring Tuff of the Paintbrush Group.

4. Information for calculating water-level altitude:

Reference point: Top of metal tag on well casing, altitude 1,123.40 m (surveyed by U.S. Geological Survey, 1984).

Measuring point: Top of access tube, $0.314 \mathrm{~m}$ above reference point.

Depth correction for borehole deviation from vertical: $0.030 \mathrm{~m}$, based on approximate depth to water of 347 m (1990 data).

Well USW WT-10 was measured hourly and periodically during 1995 . Hourly measurements were made until September 5, 1995, the day the transducer was removed from the well. During the period of hourly measurements, four calibrations of two transducers were performed. In addition, a calibration was completed on December 22, 1994. This calibration was used to calculate water-level altitudes at the beginning of 1995 . Results of the transducer calibrations are as follows:

\begin{tabular}{cccccc}
\hline $\begin{array}{c}\text { Transducer serial } \\
\text { number }\end{array}$ & $\begin{array}{c}\text { Calibration } \\
\text { date }\end{array}$ & $\begin{array}{c}\text { Slope } \\
\text { (meters/ } \\
\text { millivolt) }\end{array}$ & $\begin{array}{c}\text { Coefficient of } \\
\text { determination }\end{array}$ & $\begin{array}{c}\text { Water-level } \\
\text { altitude } \\
\text { (meters) }\end{array}$ & $\begin{array}{c}\text { Method of measuring } \\
\text { water level }\end{array}$ \\
\hline 592476 & $12-22-94$ & 0.089 & 1.00 & 776.07 & Tag with transducer \\
592476 & $04-05-95$ & .088 & 1.00 & 776.12 & Tag with transducer \\
592476 & $06-15-95$ & .091 & 0.99 & 776.16 & Chain \#3 \\
670686 & $06-15-95$ & .087 & 1.00 & 776.16 & Chain \#3 \\
670686 & $09-05-95$ & .087 & 1.00 & 776.05 & Chain \#4 \\
\hline
\end{tabular}

Bad data were removed from June 11 through 15, 1995. The bad data were due to problems with the transducer. The transducer was replaced on June 15. Daily mean values were not calculated for these dates. All other hourly transducer data for 1995 are considered to be valid.

Following the removal of the transducer, well USW WT-10 was measured periodically during the remainder of 1995. Measurements were made with Chain \#3 and Chain \#4 with the following results:

\begin{tabular}{ccc}
\hline Date & $\begin{array}{c}\text { Measured water-level altitude } \\
\text { (meters, above sea level) }\end{array}$ & $\begin{array}{c}\text { Method of measuring } \\
\text { water level }\end{array}$ \\
\hline $09-05-95$ & 776.05 & Chain \#4 \\
$12-06-95$ & 775.97 & Chain \#3 \\
\hline
\end{tabular}

Daily mean water-level altitudes from the hourly data for well USW WT-10 ranged from 776.02 to $776.29 \mathrm{~m}$ above sea level in 1995 (fig. 8). The periodic measurement made during December 1995 increased the range to a minimum of $775.97 \mathrm{~m}$. Monthly mean water-level altitudes for January through September 1995 are listed in table 9. The mean water-level altitude of the 1995 hourly data was $776.12 \mathrm{~m}$ above sea level. This mean altitude was $0.03 \mathrm{~m}$ lower than the mean altitude of $776.15 \mathrm{~m}$ for 1994 (Graves and others, 1996). 


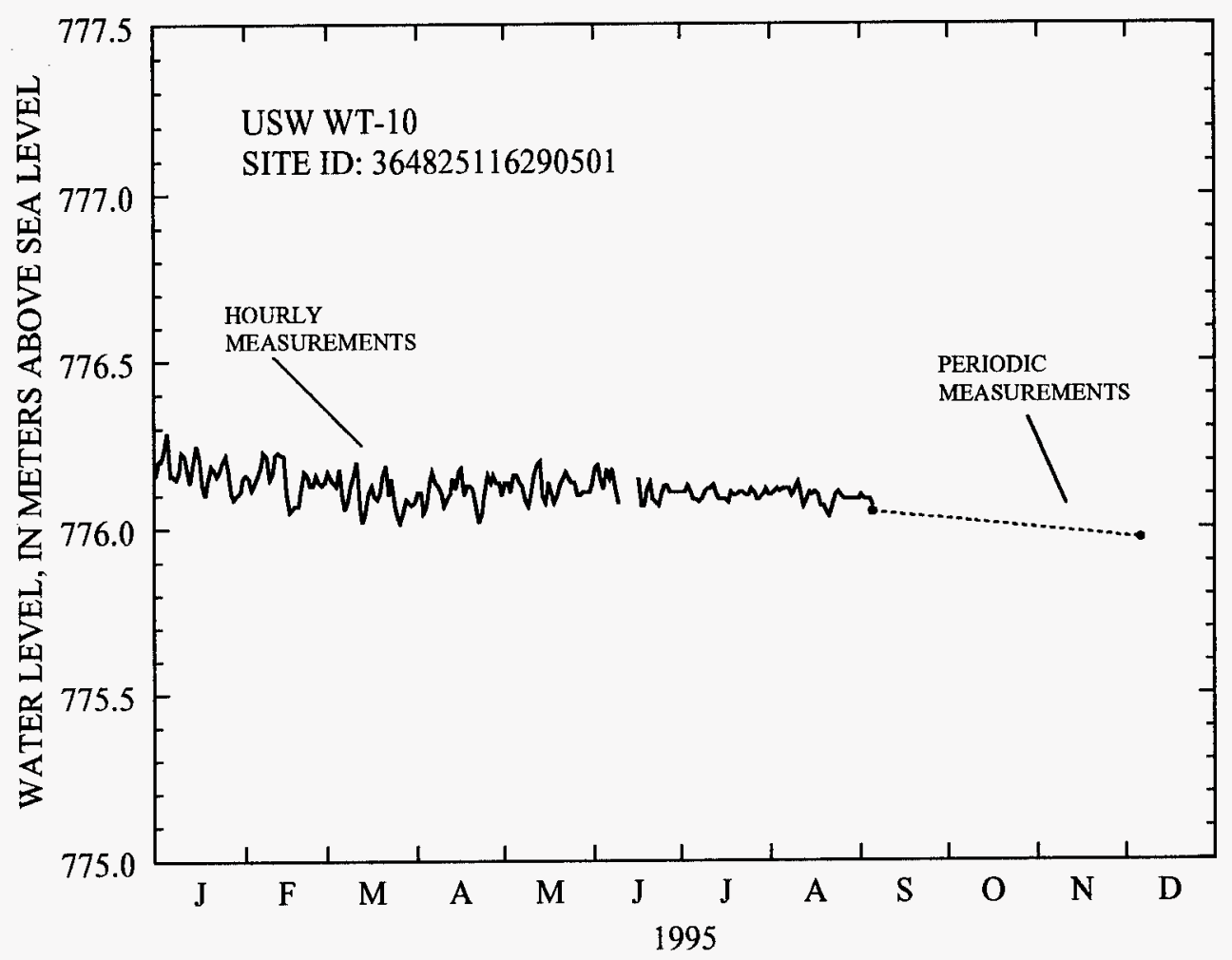

Figure 8. Water-level altitudes, 1995, for well USW WT-10.

Table 9. Monthly mean water-level altitudes, 1995, for well USW WT-10.

[Monthly means were calculated regardless of the number of missing data. Daily means were not calculated if 6 or more consecutive hours of data were missing; --, data not available; NA, not applicable, well not instrumented during this month]

\begin{tabular}{lcc}
\hline Month & $\begin{array}{c}\text { Monthly mean } \\
\text { water-level altitude } \\
\text { (meters, above sea level) }\end{array}$ & $\begin{array}{c}\text { Number of missing dally } \\
\text { means }\end{array}$ \\
\hline January & 776.17 & 0 \\
February & 776.15 & 0 \\
March & 776.11 & 0 \\
April & 776.12 & 0 \\
May & 776.13 & 0 \\
June & 776.12 & 5 \\
July & 776.10 & 0 \\
August & 776.10 & 0 \\
September & 776.09 & 0 \\
October & -- & NA \\
November & -- & NA \\
December & -- & NA \\
\hline
\end{tabular}




\section{Well USW WT-11}

Information about the history of well USW WT-11 and about previous data from the well was obtained from various sources. These sources are: Robison (1984); Robison (U.S. Geological Survey, written commun., 1986); Robison and others (1988); and Fenix \& Scisson, Inc. (1986a, 1987c).

Well specifications

1. Location and identification:

Latitude and longitude: $36^{\circ} 46^{\prime} 49^{\prime \prime} \mathrm{N} . ; 116^{\circ} 28^{\prime} 02^{\prime \prime} \mathrm{W}$.

Nevada State Central Zone Coordinates (m): N 225,269; E 170,193.

U.S. Geological Survey Site ID: 364649116280201.

2. Drilling and casing information:

Well started: August 3, 1983.

Well completed: August 9, 1983.

Drilling method: Rotary, using rock bits and air-foam circulating medium; core obtained from bottom of the borehole.

Bit diameter below water level: $222 \mathrm{~mm}$.

Casing: Surface casing only, to a depth of $14 \mathrm{~m}$.

Total drilled depth: $441 \mathrm{~m}$.

3. Access to and description of depth interval for measuring water levels:

62-mm inside-diameter tubing that has a 3.6-m-long well screen on bottom, extending from land surface to a depth of $416 \mathrm{~m}$; saturated interval of the borehole is within the Topopah Spring Tuff of the Paintbrush Group and the Calico Hills Formation.

4. Information for calculating water-level altitude:

Reference point: Top of metal tag on well casing; altitude 1,094.11 m (surveyed by U.S. Geological Survey, 1984).

Measuring point: Top of access tube, $0.311 \mathrm{~m}$ above reference point.

Depth correction for borehole deviation from vertical: $0.116 \mathrm{~m}$, based on approximate depth to water of $363 \mathrm{~m}$ (1990 data).

Well USW WT-11 was measured periodically during 1995. Measurements were made with Chain \#3 and Chain \#4 with the following results:

\begin{tabular}{rcc}
\hline Date & $\begin{array}{c}\text { Measured water-level altitude } \\
\text { (meters, above sea level) }\end{array}$ & $\begin{array}{c}\text { Method of measuring } \\
\text { water level }\end{array}$ \\
\hline $01-17-95$ & 730.74 & Chain \#4 \\
$02-21-95$ & 730.67 & Chain \#4 \\
$04-05-95$ & 730.69 & Chain \#3 \\
$04-19-95$ & 730.76 & Chain \#3 \\
$05-17-95$ & 730.66 & Chain \#3 \\
$06-22-95$ & 730.62 & Chain \#3 \\
$08-29-95$ & 730.67 & Chain \#3 \\
$12-06-95$ & 730.68 & Chain \#3 \\
\hline
\end{tabular}


Water-level altitudes for well USW WT-11 ranged from 730.62 to $730.76 \mathrm{~m}$ above sea level in 1995 (fig. 9). The mean water-level altitude of the 1995 periodic data was $730.69 \mathrm{~m}$. This mean altitude was $0.01 \mathrm{~m}$ higher than the mean altitude of $730.68 \mathrm{~m}$ for 1994 (Graves and others, 1996).

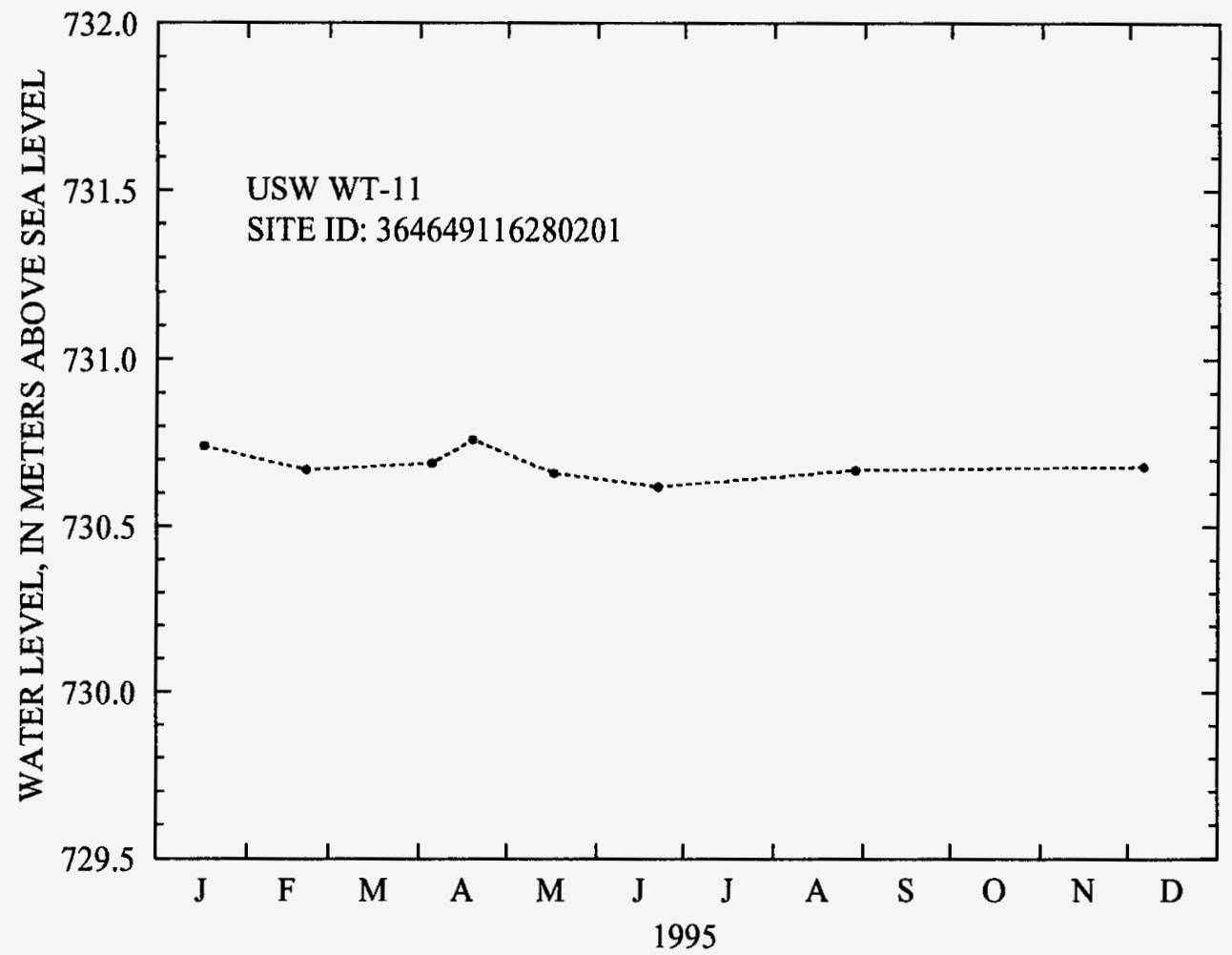

Figure 9. Water-level altitudes, 1995, for well USW WT-11.

\section{Well UE-25 WT\#12}

Information about the history of well UE-25 WT\#12 and about previous data from the well was obtained from various sources. These sources are: Robison (1984); Robison (U.S. Geological Survey, written commun., 1986); Robison and others (1988); Holmes \& Narver, Inc. (written commun., 1986); and Fenix \& Scisson, Inc. (1986a, 1987c).

Well specifications

1. Location and identification:

Latitude and longitude: $36^{\circ} 46^{\prime} 56^{\prime \prime} \mathrm{N}$; $116^{\circ} 26^{\prime} 16^{\prime \prime} \mathrm{W}$.

Nevada State Central Zone Coordinates (m): N 225,468; E 172,825.

U.S. Geological Survey Site ID: 364656116261601.

2. Drilling and casing information:

Well started: August 11, 1983.

Well completed: August 16, 1983. 
Drilling method: Rotary, using rock bits and air-foam circulating medium; core obtained from bottom of the borehole.

Bit diameter below water level: $222 \mathrm{~mm}$.

Casing: Surface casing only, to a depth of $21.3 \mathrm{~m}$.

Total drilled depth: $399 \mathrm{~m}$.

3. Access to and description of depth interval for measuring water levels:

From January 1 through July 7, 1995, the monitoring string used in well UE-25 WT\#12 was a 62-mm insidediameter tubing that had a 3.7-m-long well screen on the bottom; tubing and attached screen extended from land surface to a depth of $388.9 \mathrm{~m}$. Between July 7 and 10, 1995, this monitoring string was pulled from the well to prepare the well for a series of single-well aquifer tests. On July 27 and 28, 1995, a new monitoring string was installed in the well. Dimensions of this monitoring string are 62-mm inside-diameter tubing with a 2.44-m-long well screen on the bottom; tubing and attached screen extend from land surface to a depth of $386.73 \mathrm{~m}$.

The saturated interval of the borehole is within the Topopah Spring Tuff of the Paintbrush Group and the Calico Hills Formation.

4. Information for calculating water-level altitude:

Reference point: Top of metal tag on well casing, altitude 1,074.74 m (surveyed by U.S. Geological Survey, 1984).

Measuring point: Top of access tube, $0.305 \mathrm{~m}$ above reference point for January 1 through July 7, 1995. Top of access tube, $0.171 \mathrm{~m}$ above reference point for July 28 through December 31, 1995.

Depth correction for borehole deviation from vertical: $0.183 \mathrm{~m}$, based on approximate depth to water of $345 \mathrm{~m}$ (1990 data).

From August 17, through September 19, 1995, well UE-25 WT\#12 was equipped with a progressive cavity pump and a series of 11 single-well aquifer tests were conducted (O'Brien, 1997). The well was pumped at a rate of 1.08 to $1.67 \mathrm{~L} / \mathrm{s}$, with length of time of pumping ranging from 0.9 to 151.8 hours. Total ground water withdrawal from the well was approximately $1,600 \mathrm{~m}^{3}$. Maximum drawdown in the well was 18 meters, occurring during the 151.8 hour test. Observations made during the series of tests indicated that within 1 hour of stopping the pump for each test, the water level in the well had fully recovered to prepumping levels.

During the single-well aquifer tests, well UE-25 WT\#12 was monitored continuously with a transducer and data logger. However, the aquifer-test drawdown data were not included in this report because the pumpage did not cause long-term declines in the water level. On the contrary, there was actually a rise in water level following the series of tests instead of a decline which might have been expected (fig 10). Complete information on the aquifer test conducted at well UE-25 WT\#12 can be found in O'Brien (1997). 
Well UE-25 WT\#12 was measured periodically during 1995. Measurements were made with Chain \#3 and Chain \#4 with the following results:

\begin{tabular}{rcc}
\hline Date & $\begin{array}{c}\text { Measured water-level altitude } \\
\text { (meters, above sea level) }\end{array}$ & $\begin{array}{c}\text { Method of measuring } \\
\text { water level }\end{array}$ \\
\hline $01-30-95$ & 729.39 & Chain \#4 \\
$02-24-95$ & 729.41 & Chain \#3 \\
$03-23-95$ & 729.51 & Chain \#3 \\
$04-24-95$ & 729.48 & Chain \#3 \\
$05-22-95$ & 729.48 & Chain \#3 \\
$06-21-95$ & 729.39 & Chain \#3 \\
$08-17-95$ & 729.39 & Chain \#3 \\
$09-19-95$ & 729.51 & Chain \#4 \\
$09-27-95$ & 729.40 & Chain \#3 \\
$09-29-95$ & 729.34 & Chain \#3 \\
$12-13-95$ & 729.42 & Chain \#3 \\
\hline
\end{tabular}

Water-level altitudes for well UE-25 WT\#12 ranged from 729.34 to $729.51 \mathrm{~m}$ above sea level in 1995 (fig. 10) The mean water-level altitude of the 1995 periodic data was $729.43 \mathrm{~m}$ above sea level. This mean altitude was the same as the mean altitude of $729.43 \mathrm{~m}$ for 1994 (Graves and others, 1996).

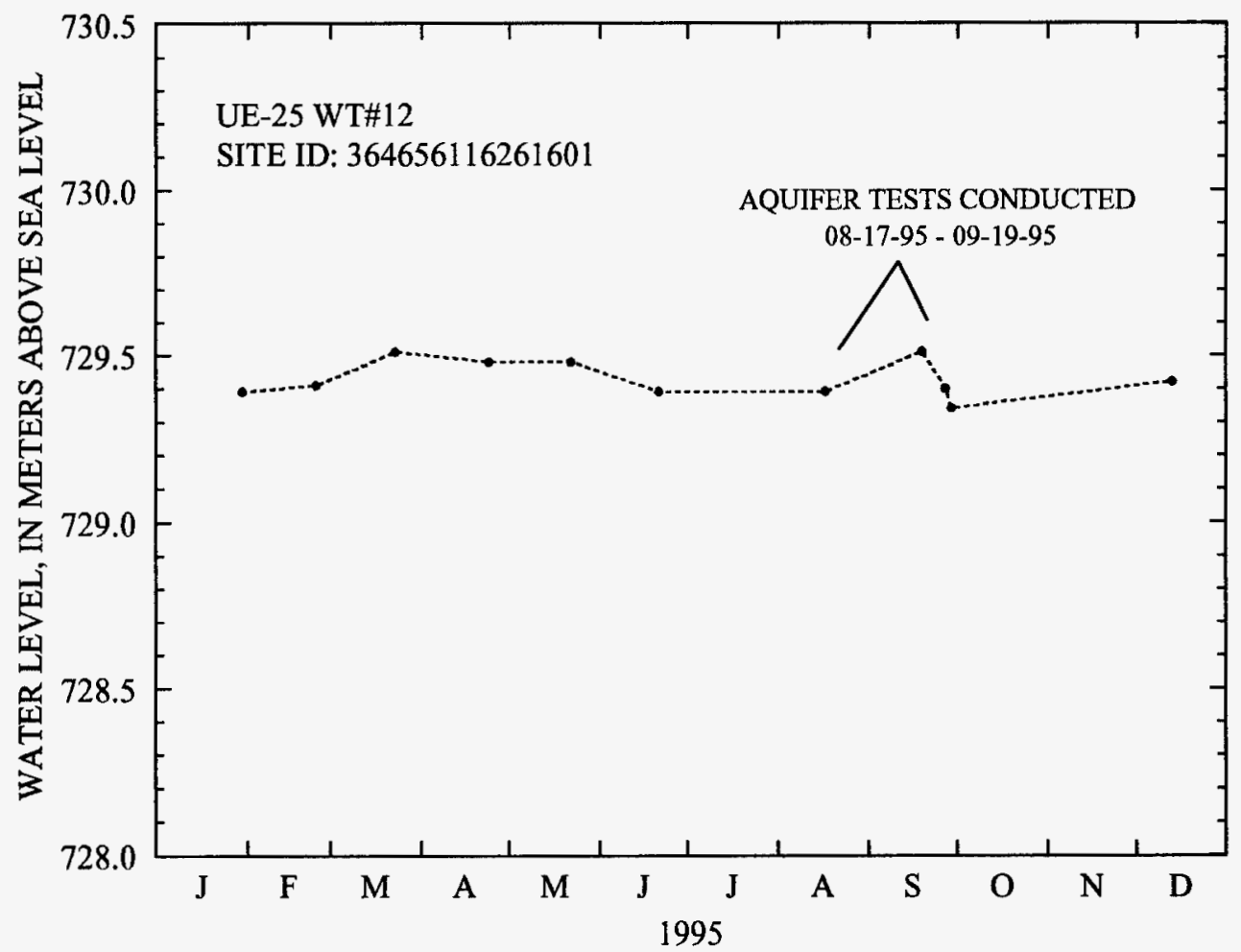

Figure 10. Water-level altitudes, 1995, for well UE-25 WT\#12. 


\section{Well UE-25 WT\#13}

Information about the history of well UE-25 WT\#13 and about previous data from the well was obtained from various sources. These sources are: Robison (1984); Robison (U.S. Geological Survey, written commun., 1986); Robison and others (1988); and Fenix \& Scisson, Inc. (1986a, 1987c).

Well specifications

1. Location and identification:

Latitude and longitude: $36^{\circ} 49^{\prime} 43^{\prime \prime} \mathrm{N}$.; $116^{\circ} 231^{\prime} 51^{\prime \prime} \mathrm{W}$.

Nevada State Central Zone Coordinates (m): N 230,647; E 176,405.

U.S. Geological Survey Site ID: 364945116235001.

2. Drilling and casing information:

Well started: June 29, 1983.

Well completed: July 7, 1983.

Drilling method: Rotary, using rock bits and air-foam circulating medium; core obtained from bottom of the borehole.

Bit diameter below water level: $222 \mathrm{~mm}$.

Casing: Surface casing only, to a depth of $68 \mathrm{~m}$.

Total drilled depth: $354 \mathrm{~m}$.

3. Access to and description of depth interval for measuring water levels:

62-mm inside-diameter tubing that has a 3.6-m-long well screen on bottom, extending from land surface to a depth of $346 \mathrm{~m}$; saturated interval of the borehole is within the Topopah Spring Tuff of the Paintbrush Group.

4. Information for calculating water-level altitude:

Reference point: Top of metal tag on well casing; altitude $1,032.51 \mathrm{~m}$ (surveyed by U.S. Geological Survey, 1984).

Measuring point: Top of access tube, $0.305 \mathrm{~m}$ above reference point.

Depth correction for borehole deviation from vertical: $0.012 \mathrm{~m}$, based on approximate depth to water of $304 \mathrm{~m}$ (1990 data).

Well UE-25 WT\#13 was measured periodically during 1995. Measurements were made with Chain \#3 and Chain \#4 with the following results:

\begin{tabular}{rcc}
\hline Date & $\begin{array}{c}\text { Measured water-level altitude } \\
\text { (meters, above sea level) }\end{array}$ & $\begin{array}{c}\text { Method of measuring } \\
\text { water level }\end{array}$ \\
\hline $01-26-95$ & 729.13 & Chain \#4 \\
$03-03-95$ & 729.15 & Chain \#3 \\
$03-22-95$ & 729.19 & Chain \#3 \\
$04-13-95$ & 729.21 & Chain \#3 \\
$05-10-95$ & 729.14 & Chain \#3 \\
$06-20-95$ & 729.21 & Chain \#3 \\
$07-24-95$ & 729.23 & Chain \#3 \\
$08-30-95$ & 729.19 & Chain \#3 \\
$12-04-95$ & 729.13 & Chain \#3 \\
\hline
\end{tabular}


Water-level altitudes for well UE-25 WT\#13 ranged from 729.13 to $729.23 \mathrm{~m}$ above sea level in 1995 (fig. 11). The mean water-level altitude of the 1995 periodic data was $729.18 \mathrm{~m}$ above sea level. This mean altitude was $0.01 \mathrm{~m}$ higher than the mean altitude of $729.17 \mathrm{~m}$ of 1994 (Graves and others, 1996).

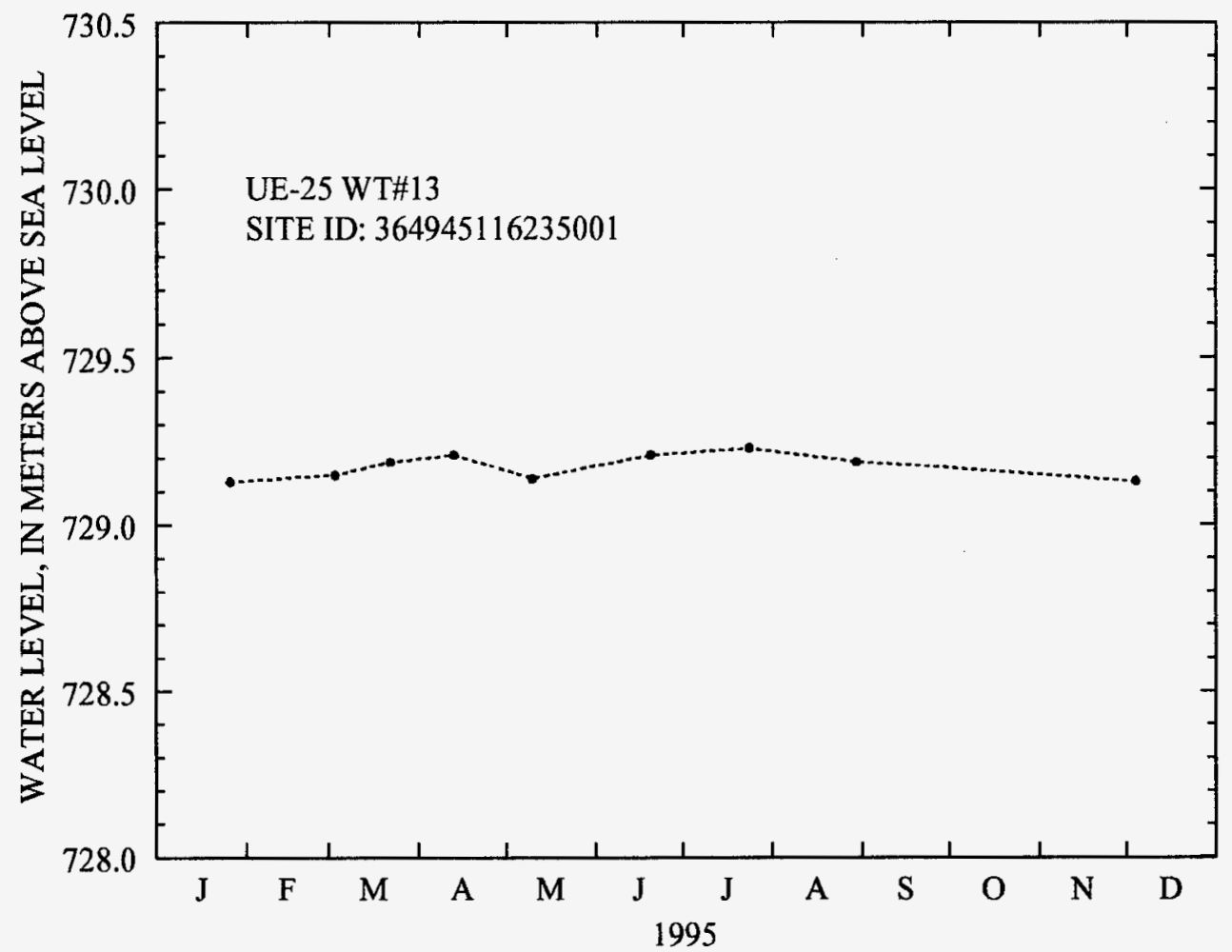

Figure 11. Water-level altitudes, 1995, for well UE-25 WT\#13.

\section{Well UE-25 WT\#14}

Information about the history of well UE-25 WT\#14 and about previous data from the well was obtained from various sources. These sources are: Robison (1984); Robison (U.S. Geological Survey, written commun., 1986); Robison and others (1988); Holmes \& Narver, Inc. (written commun., 1986); and Fenix \& Scisson, Inc. (1986a, 1987c).

Well specifications

1. Location and identification:

Latitude and longitude: $36^{\circ} 50^{\prime} 32^{\prime \prime} \mathrm{N}$.; $116^{\circ} 24^{\prime} 35^{\prime \prime} \mathrm{W}$.

Nevada State Central Zone Coordinates (m): N 232,151; E 175,324.

U.S. Geological Survey Site ID: 365032116243501.

2. Drilling and casing information:

Well started: August 17, 1983.

Well completed: September 30, 1983.

Drilling method: Rotary, using rock bits and air-foam circulating medium; core obtained from bottom of the borehole. 
Bit diameter below water level: $222 \mathrm{~mm}$.

Casing: Surface casing only, to a depth of $36.6 \mathrm{~m}$.

Total drilled depth: $399 \mathrm{~m}$.

3. Access to and description of depth interval for measuring water levels:

62-mm inside-diameter tubing that has a 3.7-m-long well screen on the bottom; tubing and attached screen extend from land surface to a depth of $397.2 \mathrm{~m}$; saturated interval of the borehole is within the Topopah Spring Tuff of the Paintbrush Group and the Calico Hills Formation.

4. Information for calculating water-level altitude:

Reference point: Top of metal tag on well casing, altitude 1,076.05 m (surveyed by U.S. Geological Survey, 1984).

Measuring point: Top of access tube, $0.311 \mathrm{~m}$ above reference point.

Depth correction for borehole deviation from vertical: $0.085 \mathrm{~m}$, based on approximate depth to water of 346 m (1990 data).

Well UE-25 WT\#14 was measured hourly and periodically during 1995 . Hourly measurements were made until September 26, 1995, the day the transducer was removed from the well. During the period of hourly measurements, four calibrations of one transducer were performed. In addition, a calibration was completed on September 20,1994. This calibration was used to calculate water-level altitudes at the beginning of 1995 . Results of the transducer calibrations are as follows:

\begin{tabular}{cccccl}
\hline $\begin{array}{c}\text { Transducer serial } \\
\text { number }\end{array}$ & $\begin{array}{c}\text { Calibration } \\
\text { date }\end{array}$ & $\begin{array}{c}\text { Slope } \\
\text { (meters/ } \\
\text { millivolt) }\end{array}$ & $\begin{array}{c}\text { Coefficient of } \\
\text { determination }\end{array}$ & $\begin{array}{c}\text { Water-level } \\
\text { altitude } \\
\text { (meters) }\end{array}$ & $\begin{array}{c}\text { Method of measuring } \\
\text { water level }\end{array}$ \\
\hline 592473 & $09-20-94$ & 0.088 & 1.00 & 729.60 & Tag with transducer \\
592473 & $01-24-95$ & .089 & 1.00 & 729.64 & Tag with transducer \\
592473 & $05-16-95$ & .089 & 1.00 & 729.71 & Chain \#3 \\
592473 & $06-28-95$ & .088 & 1.00 & 729.63 & Tag with transducer \\
592473 & $09-26-95$ & .088 & 1.00 & 729.68 & Chain \#3 \\
\hline
\end{tabular}

Spikes were removed from the transducer data on May 16 and June 28, 1995. These spikes were due to the calibration of the transducer on these dates. Spikes were also removed on June 27, 1995. The reason for this spike is not known. All other hourly transducer data for 1995 are considered to be valid.

Following the removal of the transducer, well UE-25 WT\#14 was measured periodically during the remainder of 1995 . Measurements were made with Chain $\# 3$ with the following results:

\begin{tabular}{ccc}
\hline Date & $\begin{array}{c}\text { Measured water-level altitude } \\
\text { (meters, above sea level) }\end{array}$ & $\begin{array}{c}\text { Method of measuring } \\
\text { water level }\end{array}$ \\
\hline $09-26-95$ & 729.68 & Chain \#3 \\
$12-04-95$ & 729.63 & Chain \#3 \\
\hline
\end{tabular}

Daily mean water-level altitudes from the hourly data for well UE-25 WT\#14 ranged from 729.55 to $729.75 \mathrm{~m}$ above sea level in 1995 (fig. 12). Monthly mean water-level altitudes for January through September 1995 are listed in table 10. The mean water-level altitude of the 1995 hourly data was $729.65 \mathrm{~m}$ above sea level. This mean altitude was $0.04 \mathrm{~m}$ higher than the mean altitude of $729.61 \mathrm{~m}$ for 1994 (Graves and others, 1996). 


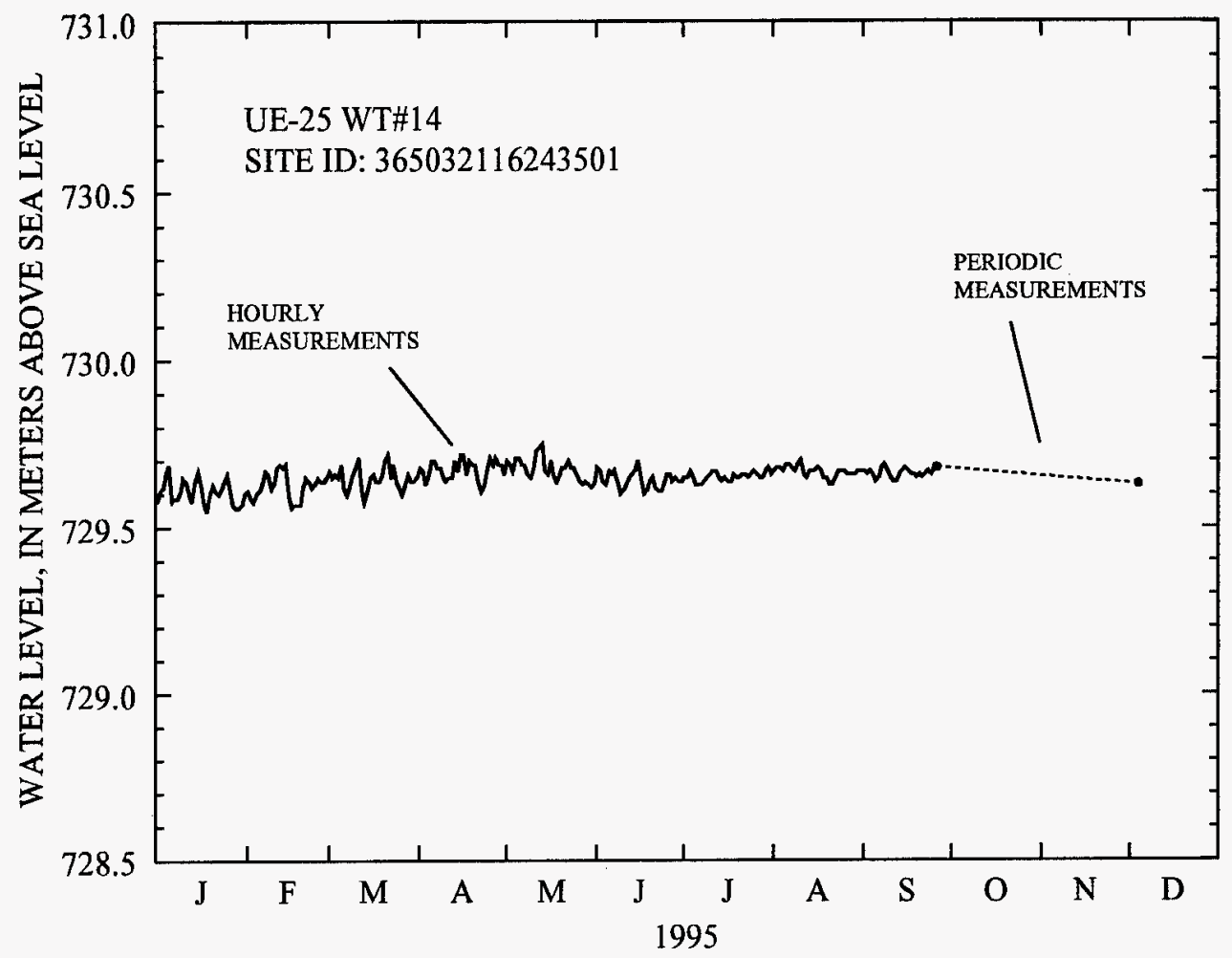

Figure 12. Water-level altitudes, 1995, for well UE-25 WT\#14.

Table 10. Monthly mean water-level altitudes, 1995, for well LE-25 WT\#14.

[Monthly means were calculated regardless of the number of missing data. Daily means were not calculated if 6 or more consecutive hours of data were missing; --, data not available; NA, not applicable, well not instrumented during this month]

\begin{tabular}{lcc}
\hline Month & $\begin{array}{c}\text { Monthly mean } \\
\text { water-level altitude } \\
\text { (meters, above sea level) }\end{array}$ & $\begin{array}{c}\text { Number of missing daily } \\
\text { means }\end{array}$ \\
\hline January & 729.61 & 0 \\
February & 729.63 & 0 \\
March & 729.65 & 0 \\
April & 729.67 & 0 \\
May & 729.68 & 0 \\
June & 729.64 & 0 \\
July & 729.65 & 0 \\
August & 729.67 & 0 \\
September & 729.66 & 0 \\
October & -- & NA \\
November & -- & NA \\
December & -- & NA \\
\hline
\end{tabular}




\section{Well UE-25 WT\#15}

Information about the history of well UE-25 WT\#15 and about previous data from the well was obtained from various sources. These sources are: Robison (1984); Robison (U.S. Geological Survey, written commun., 1986); Robison and others (1988); Holmes \& Narver, Inc. (written commun., 1986); and Fenix \& Scisson, Inc. (1986a, 1987c).

Well specifications

1. Location and identification:

Latitude and longitude: $36^{\circ} 51^{\prime} 16^{\prime \prime} \mathrm{N}$.; $116^{\circ} 23^{\prime} 38^{\prime \prime} \mathrm{W}$.

Nevada State Central Zone Coordinates (m): N 233,512; E 176,725.

U.S. Geological Survey Site ID: 365116116233801.

2. Drilling and casing information:

Well started: November 12, 1983.

Well completed: November 22, 1983.

Drilling method: Rotary, using rock bits and air-foam circulating medium; core obtained from bottom of the borehole.

Bit diameter below water level: $222 \mathrm{~mm}$.

Casing: Surface casing only, to a depth of $38.7 \mathrm{~m}$.

Total drilled depth: $415 \mathrm{~m}$.

3. Access to and description of depth interval for measuring water levels:

62-mm inside-diameter tubing that has a 3.7-m-long well screen on the bottom; tubing and attached screen extend from land surface to a depth of $406.9 \mathrm{~m}$; saturated interval of the borehole is within the Topopah Spring Tuff of the Paintbrush Group.

4. Information for calculating water-level altitude:

Reference point: Top of metal tag on well casing, altitude 1,082.94 m (surveyed by U.S. Geological Survey, 1984).

Measuring point: Top of access tube, $0.314 \mathrm{~m}$ above reference point.

Depth correction for borehole deviation from vertical: $0.189 \mathrm{~m}$, based on approximate depth to water of $354 \mathrm{~m}$ (1990 data).

Well UE-25 WT\#15 was measured periodically during 1995. Measurements were made with Chain \#3, the 2,800 foot reference steel tape, and the multiconductor cable unit with the following results:

\begin{tabular}{ccl}
\hline Date & $\begin{array}{c}\text { Measured water-level altitude } \\
\text { (meters, above sea level) }\end{array}$ & \multicolumn{1}{c}{$\begin{array}{c}\text { Method of measuring } \\
\text { water level }\end{array}$} \\
\hline $01-11-95$ & 729.24 & 2,800 foot reference steel tape \\
$04-27-95$ & 729.34 & Multiconductor cable unit \\
$05-09-95$ & 729.22 & Chain \#3 \\
$06-20-95$ & 720.30 & Chain \#3 \\
$08-29-95$ & 729.32 & Chain \#3 \\
$12-04-95$ & 729.18 & Chain \#3 \\
\hline
\end{tabular}


Water-level altitudes for well UE-25 WT\#15 ranged from 729.18 to $729.34 \mathrm{~m}$ above sea level in 1995 (fig. 13). The mean water-level altitude of the 1995 periodic data was $729.27 \mathrm{~m}$ above sea level. This mean altitude was $0.08 \mathrm{~m}$ higher than the mean altitude of $729.19 \mathrm{~m}$ for 1994 (Graves and others, 1996).

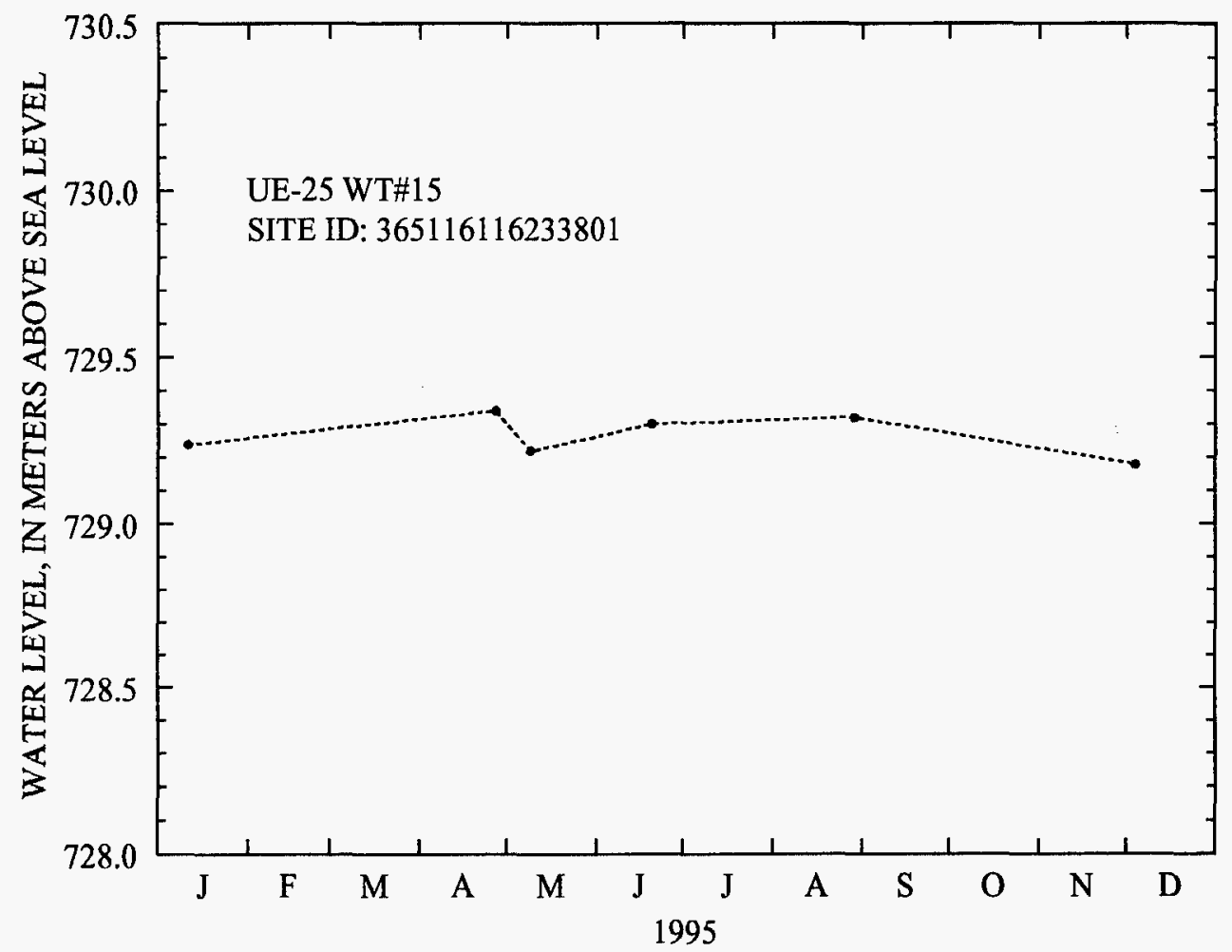

Figure 13. Water-level altitudes, 1995, for well UE-25 WT\#15.

\section{Well UE-25 WT\#16}

Information about the history of well UE-25 WT\#16 and about previous data from the well was obtained from various sources. These sources are: Robison (1984); Robison (U.S. Geological Survey, written commun., 1986); Robison and others (1988); and Fenix \& Scisson, Inc. (1986a, 1987c).

Well specifications

1. Location and identification:

Latitude and longitude: $36^{\circ} 52^{\prime} 39^{\prime \prime N}$.; $116^{\circ} 25^{\prime} 34^{\prime \prime} \mathrm{W}$.

Nevada State Central Zone Coordinates (m): N 236,043; E 173,856.

U.S. Geological Survey Site ID: 365239116253401.

2. Drilling and casing information:

Well started: November 2, 1983.

Well completed: November 10, 1983. 
Drilling method: Rotary, using rock bits and air-foam circulating medium; core obtained from bottom of the core hole.

Bit diameter below water level: $222 \mathrm{~mm}$.

Casing: Surface casing only, to a depth of $31 \mathrm{~m}$.

Total drilled depth: $521 \mathrm{~m}$.

3. Access to and description of depth interval for measuring water levels:

62-mm inside-diameter tubing that has a 3.6-m-long well screen on bottom, extending from land surface to a depth of $514 \mathrm{~m}$; saturated interval of borehole is within the Calico Hills Formation.

4. Information for calculating water-level altitude:

Reference point: Top of metal tag on well casing; altitude $1,210.63 \mathrm{~m}$ (surveyed by U.S. Geological Survey, 1984).

Measuring point: Top of access tube, $0.314 \mathrm{~m}$ above reference point.

Depth correction for borehole deviation from vertical: $0.064 \mathrm{~m}$, based on approximate depth to water of $473 \mathrm{~m}$ (1990 data).

Well UE-25 WT\#16 was measured periodically during 1995. Measurements were made with Chain \#3, Chain $\# 4$, and the 2,800 foot reference steel tape with the following results:

\begin{tabular}{rcl}
\hline Date & $\begin{array}{c}\text { Measured water-level altitude } \\
\text { (meters, above sea level) }\end{array}$ & \multicolumn{1}{c}{$\begin{array}{c}\text { Method of measuring } \\
\text { water level }\end{array}$} \\
\hline $01-30-95$ & 738.28 & Chain \#4 \\
$02-23-95$ & 738.32 & Chain \#4 \\
$03-22-95$ & 738.39 & Chain \#3 \\
$04-13-95$ & 738.31 & Chain \#3 \\
$05-09-95$ & 738.29 & Chain \#3 \\
$06-20-95$ & 738.30 & Chain \#3 \\
$07-24-95$ & 738.31 & Chain \#3 \\
$08-02-95$ & 738.30 & 2,800 foot reference steel tape \\
$08-03-95$ & 738.30 & 2,800 foot reference steel tape \\
$08-09-95$ & 738.32 & 2,800 foot reference steel tape \\
$09-05-95$ & 738.31 & Chain \#4 \\
$09-12-95$ & 738.24 & 2,800 foot reference steel tape \\
$10-23-95$ & 738.25 & 2,800 foot reference steel tape \\
$12-04-95$ & 738.23 & Chain \#3 \\
\hline
\end{tabular}

Water-level altitudes for well UE-25 WT\#16 ranged from 738.23 to $738.39 \mathrm{~m}$ above sea level in 1995 (fig. 14). The mean water-level altitude of the 1995 periodic data was $738.30 \mathrm{~m}$ above sea level. This mean altitude was $0.05 \mathrm{~m}$ lower than the mean altitude of $738.35 \mathrm{~m}$ for 1994 (Graves and others, 1996). 


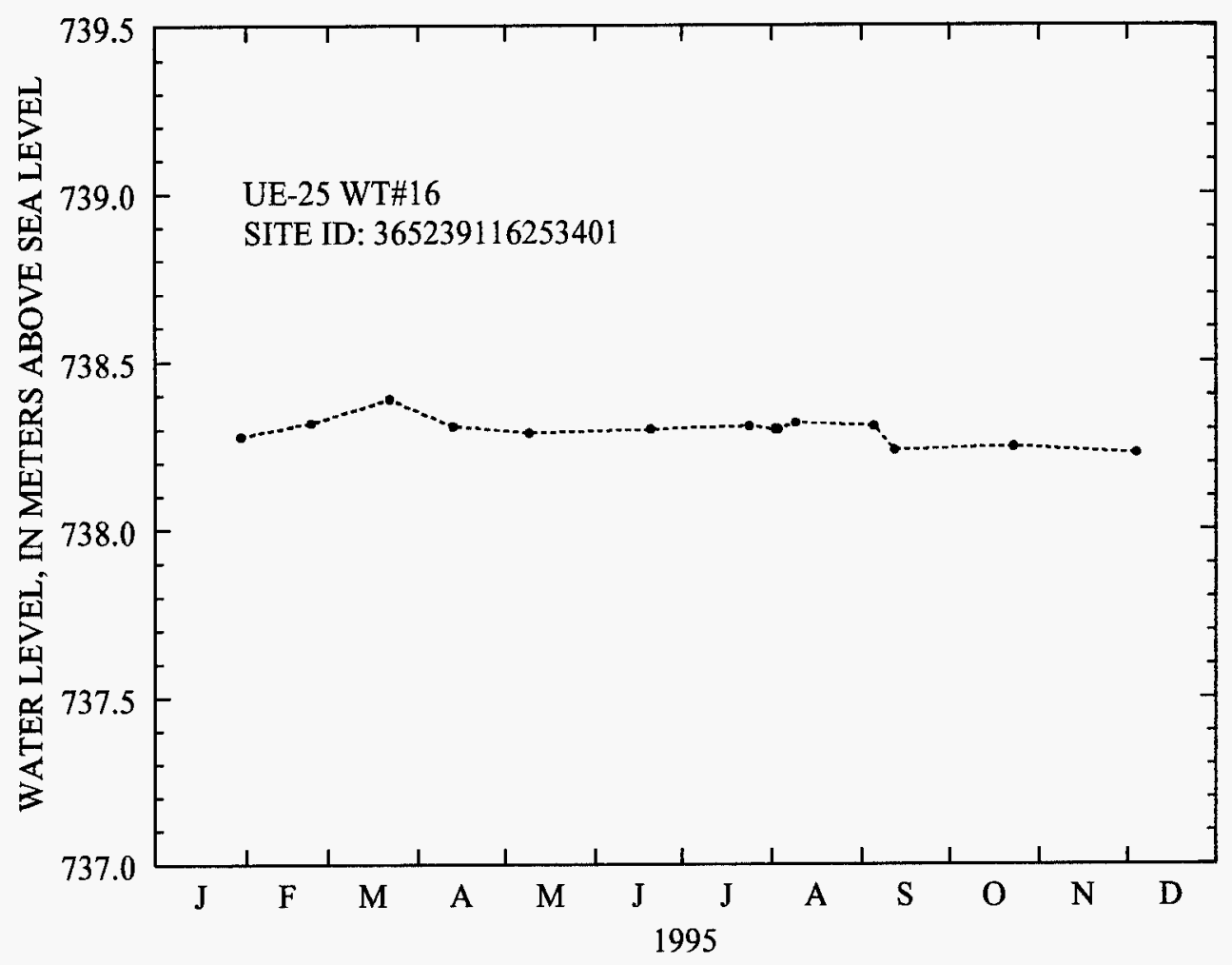

Figure 14. Water-level altitudes, 1995, for well UE-25 WT\#16.

\section{Well UE-25 WT\#17}

Information about the history of well UE-25 WT\#17 and about previous data from the well was obtained from various sources. These sources are: Robison (1984); Robison (U.S. Geological Survey, written commun., 1986); Robison and others (1988); Holmes \& Narver, Inc. (written commun., 1986); and Fenix \& Scisson, Inc. $(1986 a, 1987 \mathrm{c})$.

Well specifications

1. Location and identification:

Latitude and longitude: $36^{\circ} 48^{\prime} 22^{\prime \prime} \mathrm{N} . ; 116^{\circ} 26^{\prime} 26^{\prime \prime} \mathrm{W}$.

Nevada State Central Zone Coordinates (m): N 228,118; E 172,581.

U.S. Geological Survey Site ID: 364822116262601.

2. Drilling and casing information:

Well started: October 20, 1983.

Well completed: October 30, 1983.

Drilling method: Rotary, using rock bits and air-foam circulating medium; attempt to obtain bottom-hole core unsuccessful, core not obtained from bottom of borehole.

Bit diameter below water level: $222 \mathrm{~mm}$.

Casing: Surface casing only, to a depth of $16.8 \mathrm{~m}$.

Total drilled depth: $443 \mathrm{~m}$. 
3. Access to and description of dèpth interval for measuring water levels:

62-mm inside-diameter tubing that has a 3.7-m-long well screen on the bottom; tubing and attached screen extend from land surface to a depth of $419.4 \mathrm{~m}$; saturated interval of borehole is within the Prow Pass Tuff of the Crater Flat Group.

4. Information for calculating water-level altitude:

Reference point: Top of metal tag on well casing, altitude 1,124.06 m (surveyed by U.S. Geological Survey, 1984).

Measuring point: Top of access tube, $0.158 \mathrm{~m}$ above reference point.

Depth correction for borehole deviation from vertical: $0.482 \mathrm{~m}$, based on approximate depth to water of 394 m (1990 data).

Well UE-25 WT\#17 was measured periodically through June 1995. Water-level measurements in UE-25 WT\#17 were discontinued after June 1995. All measurements made during 1995 were made with the multiconductor cable unit with the following results:

\begin{tabular}{ccc}
\hline Date & $\begin{array}{c}\text { Measured water-level altitude } \\
\text { (meters, above sea level) }\end{array}$ & $\begin{array}{c}\text { Method of measuring } \\
\text { water level }\end{array}$ \\
\hline $03-15-95$ & 729.71 & Multiconductor cable unit \\
$04-27-95$ & 729.78 & Multiconductor cable unit \\
$06-01-95$ & 729.72 & Multiconductor cable unit \\
$06-28-95$ & 729.45 & Multiconductor cable unit \\
\hline
\end{tabular}

Water-level altitudes for well UE-25 WT\#17 ranged from 729.45 to $729.78 \mathrm{~m}$ above sea level in 1995 (fig. 15). The mean water-level altitude of the 1995 periodic data was $729.66 \mathrm{~m}$ above sea level. This mean altitude was $0.02 \mathrm{~m}$ higher than the mean altitude of $729.64 \mathrm{~m}$ for 1994 (Graves and others, 1996).

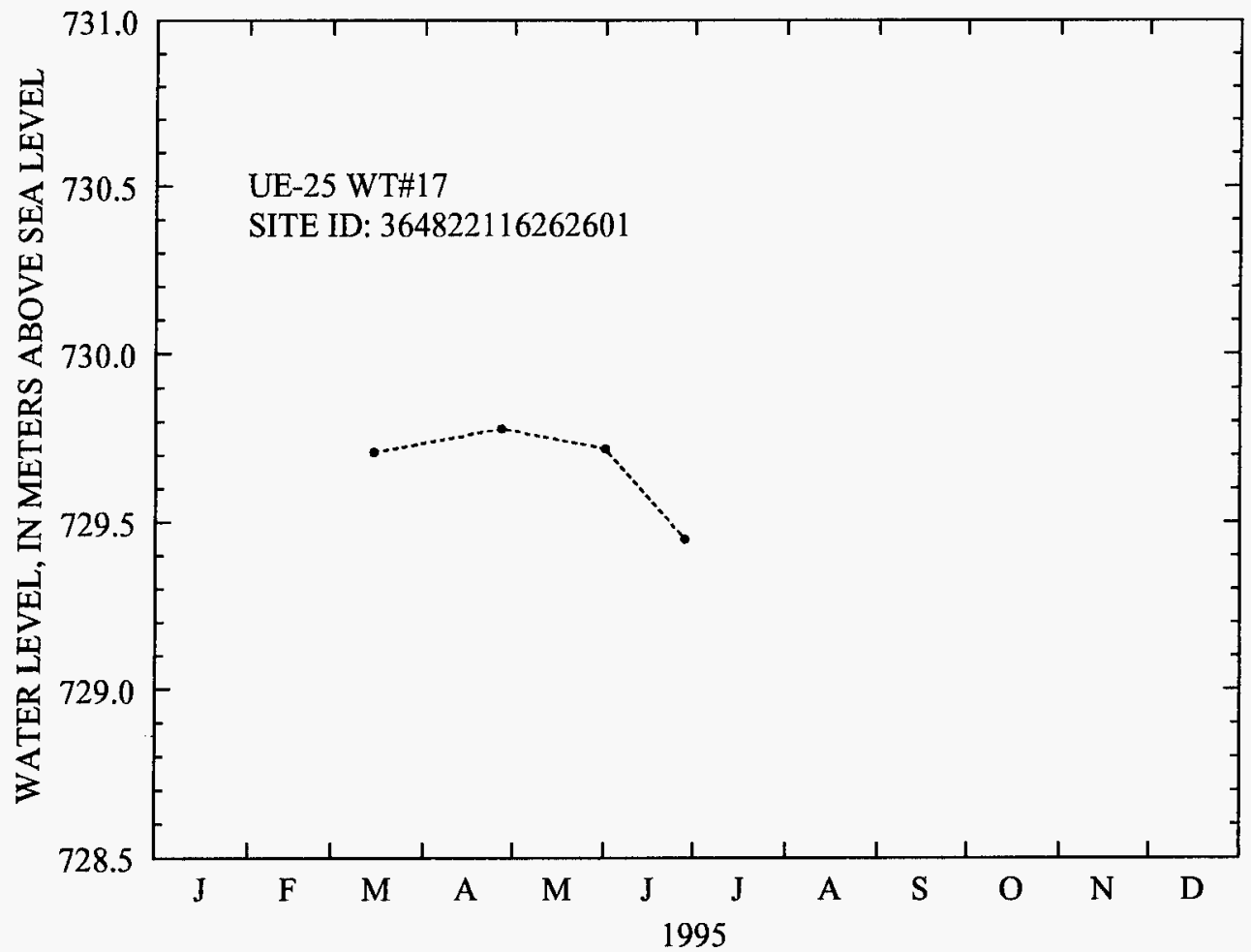

Figure 15. Water-level altitudes, 1995, for well UE-25 WT\#17. 


\section{Well UE-25 WT\#18}

Information about the history of well UE-25 WT\#18 and about previous data from the well was obtained from various sources. These sources are: Fenix \& Scisson, Inc. (1986a); Holmes \& Narver, Inc. (written commun., 1986); and Muller and Kibler (1985).

Well specifications

1. Location and identification:

Latitude and longitude: $36^{\circ} 52^{\prime} 07^{\prime \prime} \mathrm{N} ; 116^{\circ} 26^{\prime} 42^{\prime \prime} \mathrm{W}$.

Nevada State Central Zone Coordinates (m): N 235,052; E 172,168.

U.S. Geological Survey Site ID: 365207116264201.

2. Drilling and casing information:

Well started: May 9, 1984.

Well completed: May 23, 1984.

Drilling method: Rotary using rock bits and air-foam circulating medium; core obtained from bottom of the borehole.

Bit diameter below water level: $222 \mathrm{~mm}$.

Casing: Surface casing only, to a depth of $27 \mathrm{~m}$.

Total depth drilled: $623 \mathrm{~m}$.

3. Access to and description of depth interval for measuring water levels:

62-mm inside-diameter tubing that has a 3.7-m-long well screen on the bottom; tubing and attached screen originally extended from land surface to a depth of $597 \mathrm{~m}$, but tubing was extended to a depth of $609 \mathrm{~m}$, December 1990; saturated interval is within the Calico Hills Formation.

4. Information for calculating water-level altitude:

Reference point: Top of metal tag on well casing, altitude $1336.32 \mathrm{~m}$ (surveyed by U.S. Geological Survey, 1984).

Measuring point: Top of access tube, $0.210 \mathrm{~m}$ above reference point.

Depth correction for borehole deviation from vertical: $0.155 \mathrm{~m}$, based on approximate depth to water of 607 m (1990 data).

Well UE-25 WT\#18 was measured periodically during 1995. Water-level measurements in UE-25 WT\#18 were discontinued after August 1995. Water-level measurements made during May and August 1995, were determined to be bad data and were not used in this report. Measurements made during 1995 were made with Chain \#3 and Chain \#4 with the following results:

\begin{tabular}{rcl}
\hline Date & $\begin{array}{c}\text { Measured water-level altitude } \\
\text { (meters, above sea level) }\end{array}$ & $\begin{array}{c}\text { Method of measuring } \\
\text { water level }\end{array}$ \\
\hline $01-30-95$ & 730.68 & Chain \#4 \\
$03-02-95$ & 730.57 & Chain \#3 \\
$03-22-95$ & 730.55 & Chain \#3 \\
$04-10-95$ & 730.57 & Chain \#3 \\
\hline
\end{tabular}


Water-level altitudes for well UE-25 WT\#18 ranged from 730.57 to $730.68 \mathrm{~m}$ above sea level from January through April 1995 (fig. 16). The mean water-level altitude of the 1995 periodic data was $730.59 \mathrm{~m}$ above sea level. This mean altitude was $0.11 \mathrm{~m}$ lower than the mean altitude of $730.70 \mathrm{~m}$ for 1994 (Graves and others, 1996).

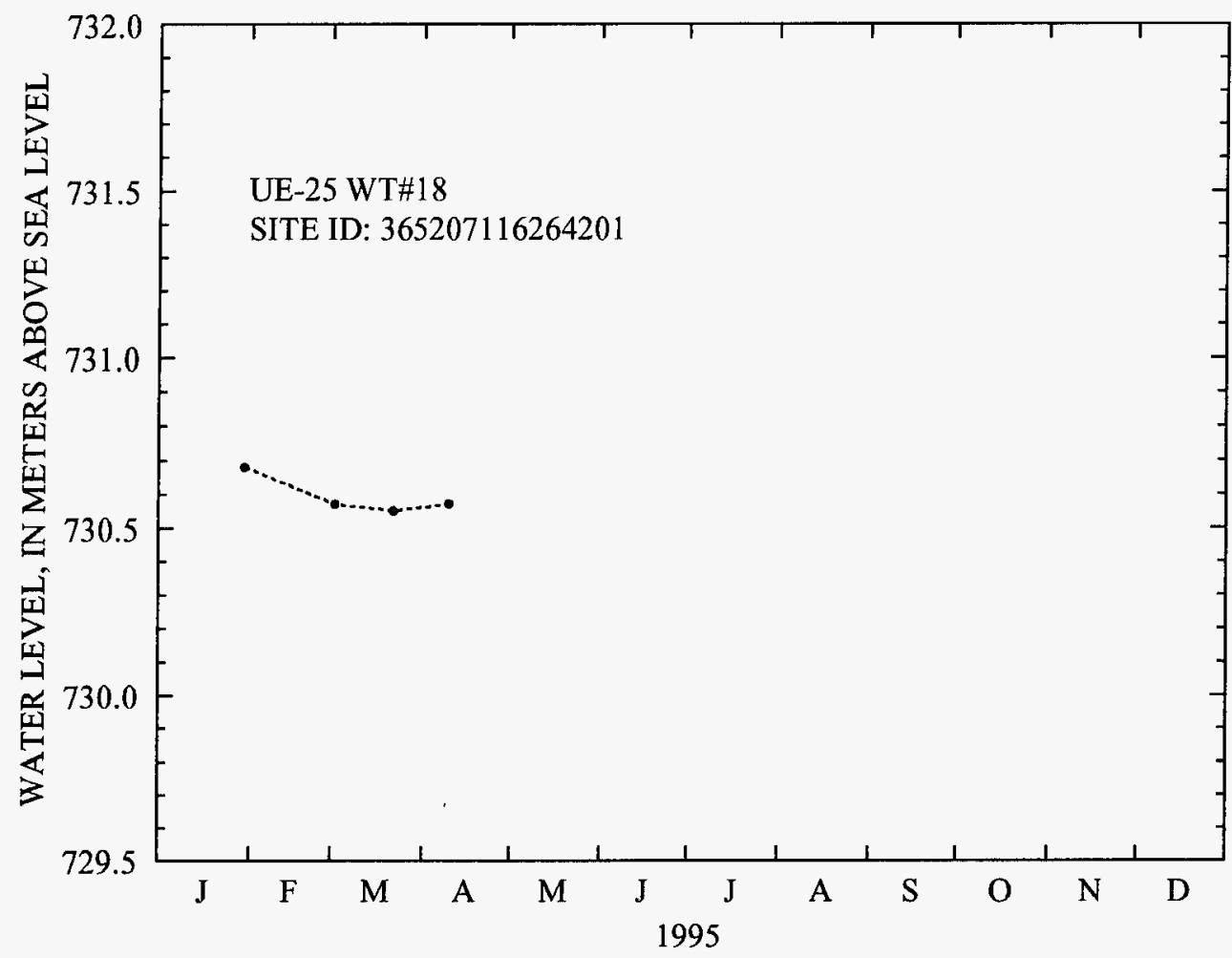

Figure 16. Water-level altitudes, 1995, for well UE-25 WT\#18.

\section{Well UE-25 b\#1}

Information about the history of well UE-25 $\mathrm{b} \# 1$ and about previous data from the well was obtained from various sources. These sources are: Lobmeyer and others (1983); Lahoud and others (1984); Robison (1984); Robison (U.S. Geological Survey, written commun., 1986); Robison and others (1988); and Fenix \& Scisson, Inc. (1986b, 1987c).

Well specifications

1. Location and identification:

Latitude and longitude: $36^{\circ} 51^{\prime} 08^{\prime \prime} \mathrm{N}$.; $116^{\circ} 26^{\prime} 23^{\prime \prime} \mathrm{W}$.

Nevada State Central Zone Coordinates (m): N 233,246; E 172,644.

U.S. Geological Survey Site ID: 365108116262301.

2. Drilling and casing information:

Well started: April 3, 1981.

Well completed: September 22, 1981. 
Drilling method: Rotary, using rock bits and air-foam circulating medium; cores obtained from selected intervals.

Bit diameter below water level: $311 \mathrm{~mm}$ to $520 \mathrm{~m} ; 222 \mathrm{~mm}$ to $650 \mathrm{~m} ; 216 \mathrm{~mm}$ from 650 to $1,220 \mathrm{~m}$.

Casing extending below water level: $226-\mathrm{mm}$ inside diameter to $518 \mathrm{~m}$; casing string is tack cemented in and perforated below the water level.

Total drilled depth: $1,220 \mathrm{~m}$.

3. Access to and description of depth interval for measuring water levels:

Upper interval:

48-mm inside diameter tubing, open ended, to depth of about $488 \mathrm{~m}$; upper interval of borehole, from near water table to top of inflatable packer, is within the Calico Hills Formation, and Prow Pass, Bullfrog, and upper Tram Tuffs of the Crater Flat Group;

Lower interval:

62-mm inside diameter tubing that has an inflatable packer on bottom end, to depth of $1,199 \mathrm{~m}$; lower interval of borehole, from below packer to bottom of well, is within the lower Tram Tuff of the Crater Flat Group and Lithic Ridge Tuff.

4. Information for calculating water-level altitude:

Reference point: Top of metal tag on well casing; altitude 1,200.73 m (surveyed by U.S. Geological Survey, 1984).

Measuring point: Top of access tubes, $0.302 \mathrm{~m}$ above reference point, upper interval; $0.134 \mathrm{~m}$ above reference point, lower interval.

Depth correction for borehole deviation from vertical: $0.244 \mathrm{~m}$, based on approximate depth to water of $470 \mathrm{~m}$ (1990 data).

Well UE-25 b\#1, upper interval was measured periodically during 1995. Measurements were made with Chain \#3 and Chain \#4 with the following results:

\begin{tabular}{rcc}
\hline Date & $\begin{array}{c}\text { Measured water-level altitude } \\
\text { (meters, above sea level) }\end{array}$ & $\begin{array}{c}\text { Mothod of measuring } \\
\text { water level }\end{array}$ \\
\hline $01-30-95$ & 730.54 & Chain \#4 \\
$03-02-95$ & 730.64 & Chain \#3 \\
$04-10-95$ & 730.62 & Chain \#3 \\
$05-10-95$ & 730.61 & Chain \#3 \\
$06-13-95$ & 730.57 & Chain \#3 \\
$07-12-95$ & 730.61 & Chain \#3 \\
$08-16-95$ & 730.65 & Chain \#3 \\
$09-14-95$ & 730.62 & Chain \#4 \\
$12-05-95$ & 730.59 & Chain \#3 \\
\hline
\end{tabular}

Water-level altitudes for well UE-25 b\#1, upper interval ranged from 730.54 to $730.65 \mathrm{~m}$ above sea level in 1995 (fig. 17). The mean water-level altitude of the 1995 periodic data was $730.61 \mathrm{~m}$ above sea level. This mean altitude was $0.01 \mathrm{~m}$ higher than the mean altitude of $730.60 \mathrm{~m}$ for 1994 (Graves and others, 1996). 


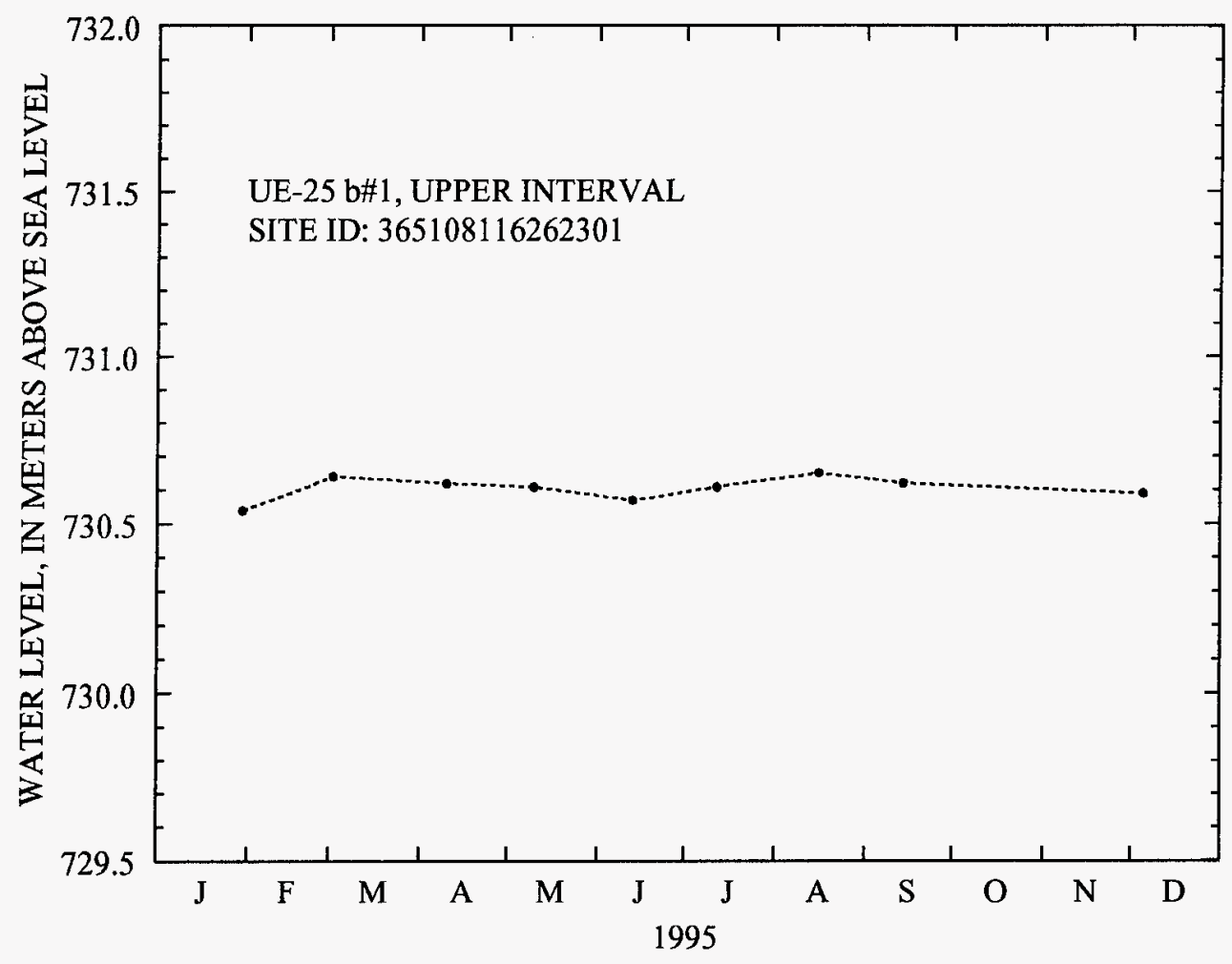

Figure 17. Water-level altitudes, 1995, for well UE-25 b\#1, upper interval.

Well UE-25 b\#1, lower interval was measured periodically during 1995. Water-level measurements in UE-25 b\#1 lower interval were discontinued after July 1995. All measurements were made with the multiconductor cable unit with the following results:

\begin{tabular}{ccc}
\hline Date & $\begin{array}{c}\text { Measured water-level altitude } \\
\text { (meters, above sea level) }\end{array}$ & $\begin{array}{c}\text { Method of measuring } \\
\text { water level }\end{array}$ \\
\hline $03-08-95$ & 730.25 & Multiconductor cable unit \\
$04-25-95$ & 730.25 & Multiconductor cable unit \\
$05-31-95$ & 729.68 & Multiconductor cable unit \\
$06-22-95$ & 729.64 & Multiconductor cable unit \\
$07-18-95$ & 730.14 & Multiconductor cable unit \\
\hline
\end{tabular}

Water-level altitudes for well UE-25 b\#1, lower interval ranged from 729.64 to $730.25 \mathrm{~m}$ above sea level in 1994 (fig. 18). The mean water-level altitude of the 1995 periodic data was $729.99 \mathrm{~m}$ above sea level. This mean altitude was $0.07 \mathrm{~m}$ lower than the mean altitude of $730.06 \mathrm{~m}$ for 1994 (Graves and others, 1996). 


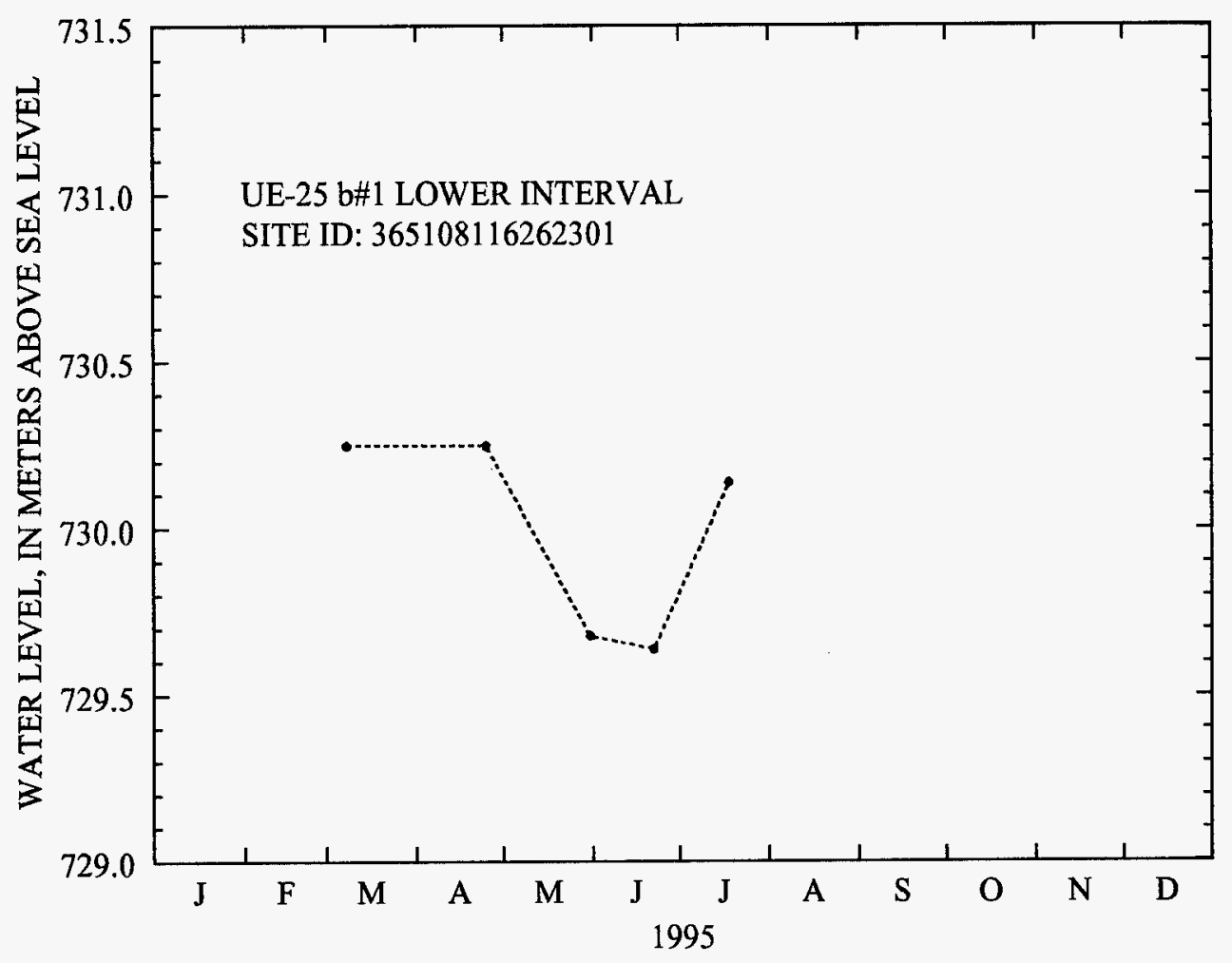

Figure 18. Water-level altitudes, 1995, for well UE-25 b\#1 lower interval.

\section{Well UE-25 p\#1}

Information about the history of well UE- $25 \mathrm{p} \# 1$ and about previous data from the well was obtained from various sources. These sources are: Craig and Johnson (1984); Craig and Robison (1984); Robison (1984);

Robison (U.S. Geological Survey, written commun., 1986); Robison and others (1988); and Fenix \& Scisson, Inc. (1986c, 1987c).

\section{Well specifications}

1. Location and identification:

Latitude and longitude: $36^{\circ} 49^{\prime} 38^{\prime \prime N}$.; $116^{\circ} 25^{\prime} 21 " \mathrm{~W}$.

Nevada State Central Zone Coordinates (m): N 230,481; E 174,188.

U.S. Geological Survey Site ID: 364938116252102.

2. Drilling and casing information:

Well started: November 13, 1982.

Well completed: May 24, 1983.

Drilling method: Rotary, using rock bits and air-foam circulating medium; cores obtained from selected intervals.

Bit diameter below water level: $375 \mathrm{~mm}$ to $487 \mathrm{~m} ; 251 \mathrm{~mm}$ from 487 to $1,304 \mathrm{~m}$; 
$17 \mathrm{~mm}$ from 1,304 to $1,317 \mathrm{~m} ; 171 \mathrm{~mm}$ from 1,317 to $1,798 \mathrm{~m} ; 156 \mathrm{~mm}$ from 1,798 to $1,805 \mathrm{~m}$.

Casing extending below water level: $255-\mathrm{mm}$ inside diameter from land surface to $477 \mathrm{~m}$; $177-\mathrm{mm}$ inside diameter from 453 to $1,297 \mathrm{~m}$; casing string is cemented in, has no perforations.

Total drilled depth: $1,805 \mathrm{~m}$.

3. Access to and description of depth interval for measuring water levels:

38-mm inside-diameter tubing, open end, to depth of $418 \mathrm{~m}$; well construction is such that water level of the tuffs of Tertiary age is not monitored. Only the water level in the underlying carbonate rocks of Paleozoic age is measured (Tertiary-Paleozoic contact is at 1,244 m).

Note: A 38-mm inside-diameter tubing, closed end, and filled with water, to a depth of $413 \mathrm{~m}$ below land surface is also installed in the well to allow access for temperature logging.

4. Information for calculating water-level altitude:

Reference point: Top of metal tag on well casing; altitude 1,114.21 m (surveyed by U.S. Geological Survey, 1984).

Measuring point: Top of access tube, $0.158 \mathrm{~m}$ above reference point.

Depth correction for borehole deviation from vertical: $0.021 \mathrm{~m}$, based on approximate depth to water of $362 \mathrm{~m}$ (1990 data).

Well UE-25 p\#1 was measured hourly during 1995. Four calibrations of one transducer were performed during 1995. In addition, calibrations on November 23, 1994, and May 8, 1996, were used to calculate water levels for 1995. Results of the transducer calibrations are as follows:

\begin{tabular}{cccccc}
\hline $\begin{array}{c}\text { Transducer serial } \\
\text { number }\end{array}$ & $\begin{array}{c}\text { Calibration } \\
\text { date }\end{array}$ & $\begin{array}{c}\text { Slope } \\
\text { (meters/ } \\
\text { millivolt) }\end{array}$ & $\begin{array}{c}\text { Coefficient of } \\
\text { determination }\end{array}$ & $\begin{array}{c}\text { Water-level } \\
\text { altitude } \\
\text { (meters) }\end{array}$ & $\begin{array}{c}\text { Method of measuring } \\
\text { water level }\end{array}$ \\
\hline 592477 & $11-23-94$ & 0.089 & 1.00 & 752.51 & Tag with transducer \\
592477 & $02-16-95$ & .088 & 1.00 & 752.50 & Chain \#4 \\
592477 & $06-08-95$ & .088 & 1.00 & 752.61 & Tag with transducer \\
592477 & $06-28-95$ & .089 & 1.00 & 752.56 & Tag with transducer \\
592477 & $11-07-95$ & .089 & 1.00 & 752.52 & Tag with transducer \\
592477 & $05-08-96$ & .088 & 1.00 & 752.67 & Chain \#3 \\
\hline
\end{tabular}

No data were collected May 11 through 14, 1995. Data were lost because of scanner problems on the DCP. Partial data were collected on May 10 and 15, 1995, for the same reason. Spikes were removed from the data on November 28 and 29, 1995. The reason for the spikes is not known. Partial data were collected November 7 and 8 , 1995, because the DCP was off line while the transducer was being calibrated. Partial data were collected December 26 and 27, 1995. The reason for the partial data for these two days is not known. Daily mean waterlevel altitudes were not calculated for May 10 through 15, November 7 through 8, or December 26 through 27, 1995. All other transducer data collected for 1995 were considered valid.

Daily mean water-level altitudes of the hourly data for well UE-25 p\#1 ranged from 752.46 to $752.66 \mathrm{~m}$ above sea level in 1995 (fig. 19). Monthly mean water-level altitudes are listed in table 11 . The mean water-level altitude of the 1995 hourly data was $752.57 \mathrm{~m}$ above sea level. This mean altitude was $0.02 \mathrm{~m}$ higher than the mean altitude of $752.55 \mathrm{~m}$ for 1994 (Graves and others, 1996). 


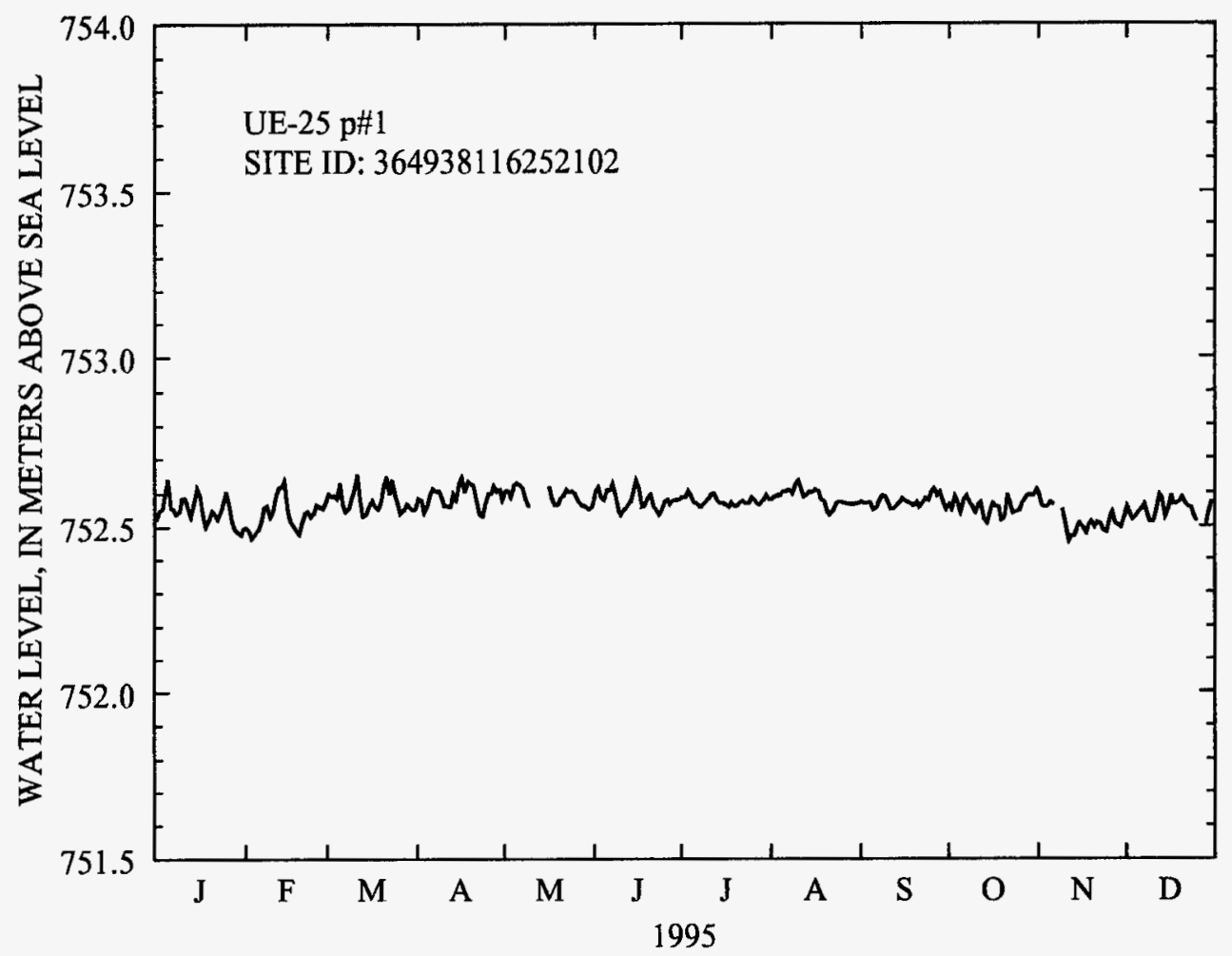

Figure 19. Water-level altitudes, 1995, for well UE-25 p\#1.

Table 11. Monthly mean water-level altitudes, 1995, for well UE-25 p\#1.

[Monthly means were calculated regardless of the number of missing data. Daily means were not calculated if 6 or more consecutive hours of data were missing]

\begin{tabular}{lcc}
\hline Month & $\begin{array}{c}\text { Monthly moan } \\
\text { water-level altitude } \\
\text { (meters, above sea level) }\end{array}$ & $\begin{array}{c}\text { Number of missing daily } \\
\text { means }\end{array}$ \\
\hline January & 752.55 & 0 \\
February & 752.54 & 0 \\
March & 752.58 & 0 \\
April & 752.59 & 0 \\
May & 752.59 & 6 \\
June & 752.58 & 0 \\
July & 752.58 & 0 \\
August & 752.59 & 0 \\
September & 752.57 & 0 \\
October & 752.56 & 0 \\
November & 752.52 & 2 \\
December & 752.55 & 2 \\
\hline
\end{tabular}




\section{Well USW VH-1}

Information about the history of well USW VH-1 and about previous data from the well was obtained from various sources. These sources are: Robison (1984); Robison (U.S. Geological Survey, written commun., 1986); Robison and others (1988); Holmes \& Narver, Inc. (written commun., 1986); and Thordarson and Howells (1987).

Well specifications

1. Location and identification:

Latitude and longitude: $36^{\circ} 47^{\prime} 32^{\prime \prime N}$.; $116^{\circ} 33^{\prime} 07^{\prime \prime} \mathrm{W}$.

Nevada State Central Zone Coordinates (m): N 226,575; E 162,649.

U.S. Geological Survey Site ID: 364732116330701.

2. Drilling and casing information:

Well started: October 28, 1980.

Well completed: February 18, 1981.

Drilling method: Rotary, using rock bits, and air-foam and polymer circulating medium.

Bit diameter below water level: $222 \mathrm{~mm}$ to $278 \mathrm{~m} ; 159 \mathrm{~mm}$ from $278 \mathrm{~m}$ to total depth.

Casing extending below water level: $177-\mathrm{mm}$ inside diameter to $278 \mathrm{~m}$.

Total drilled depth: $762 \mathrm{~m}$.

3. Access to and description of depth interval for measuring water levels:

48-mm inside-diameter tubing, open ended from land surface to $205.4 \mathrm{~m}$; saturated interval of the well is within the Tiva Canyon and Topopah Spring Tuffs of the Paintbrush Group, and the Prow Pass and Bullfrog Tuffs of the Crater Flat Group. A pump was installed in the well on July 8, 1982, at a depth of $212.8 \mathrm{~m}$.

4. Information for calculating water-level altitude:

Reference point: Top of metal tag on well casing, altitude 963.23 m (surveyed by Holmes \& Narver, Inc., March 3, 1986).

Measuring point: Top of access tube, $0.631 \mathrm{~m}$ above reference point.

Depth correction for borehole deviation from vertical: $0.049 \mathrm{~m}$, based on approximate depth to water of $184 \mathrm{~m}$ (1990 data). 
Well USW VH-1 was measured periodically during 1995. Measurements were made with Chain \#3, Chain $\# 4$, and the 2,800 foot reference steel tape with the following results:

\begin{tabular}{rcl}
\hline Date & $\begin{array}{c}\text { Measured water-level altitude } \\
\text { (meters, above sea level) }\end{array}$ & \multicolumn{1}{c}{$\begin{array}{c}\text { Method of measuring } \\
\text { water level }\end{array}$} \\
\hline $01-05-95$ & 779.53 & Chain \#4 \\
$01-12-95$ & 779.45 & Chain \#4 \\
$02-21-95$ & 779.52 & Chain \#4 \\
$03-28-95$ & 779.50 & 2,800 foot reference steel tape \\
$04-19-95$ & 779.51 & Chain \#3 \\
$05-17-95$ & 779.49 & Chain \#3 \\
$06-22-95$ & 779.45 & Chain \#3 \\
$07-19-95$ & 779.44 & Chain \#3 \\
$08-10-95$ & 779.51 & 2,800 foot reference steel tape \\
$10-24-95$ & 779.49 & 2,800 foot reference steel tape \\
$12-06-95$ & 779.50 & Chain \#3 \\
\hline
\end{tabular}

Water-level altitudes for well USW VH-1 ranged from 779.44 to $779.53 \mathrm{~m}$ above sea level in 1995 (fig. 20). The mean water-level altitude of the 1995 periodic data was $779.49 \mathrm{~m}$ above sea level. This mean altitude was $0.03 \mathrm{~m}$ higher than the mean altitude of $779.46 \mathrm{~m}$ for 1994 (Graves and others, 1996).

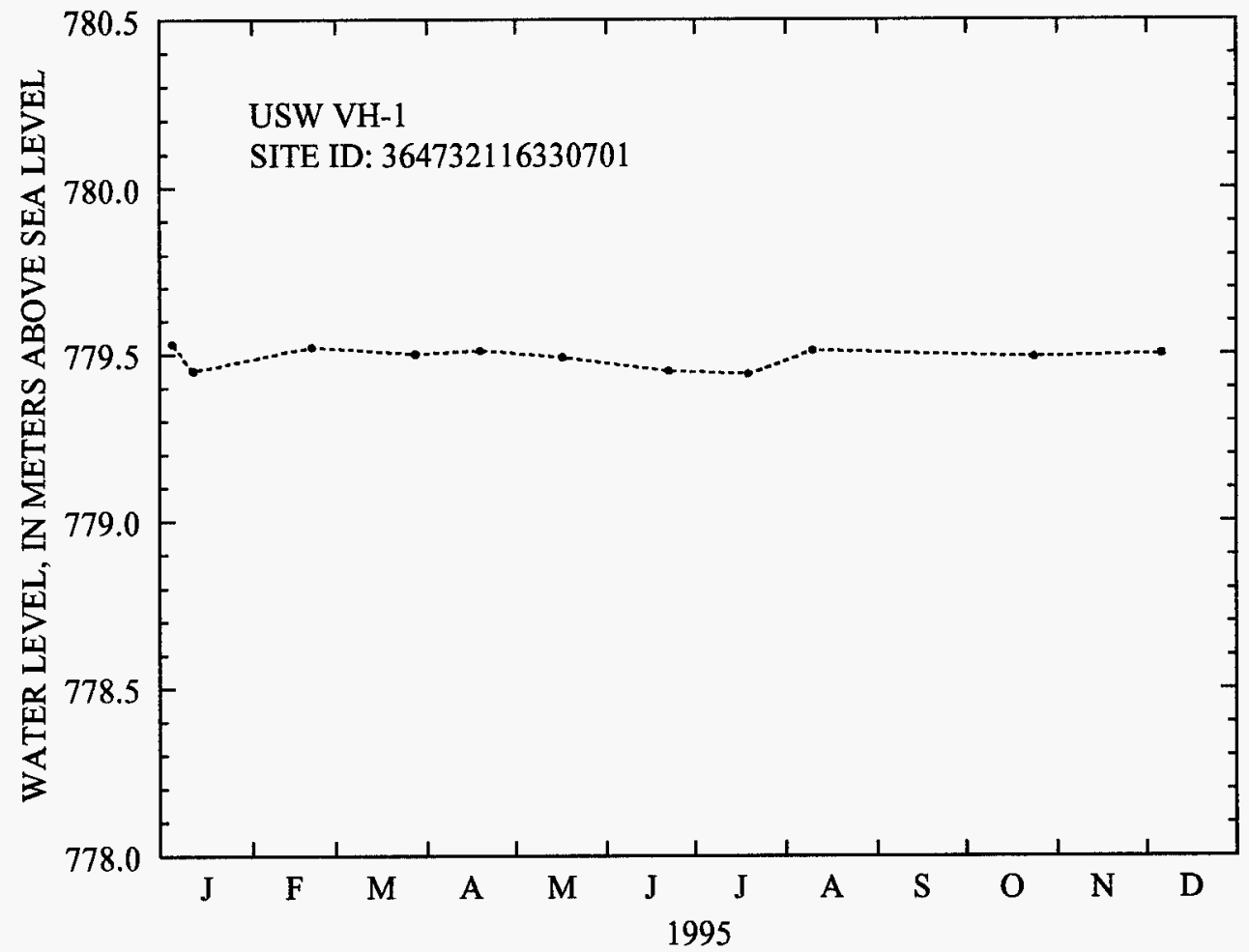

Figure 20. Water-level altitudes, 1995, for well USW VH-1. 


\section{Well USW G-2}

Information about the history of well USW G-2 and about previous data from the well was obtained from various sources. These sources are: Maldonado and Koether (1983); Robison (1984); Robison (U.S. Geological Survey, written commun., 1986); Robison and others (1988); Holmes \& Narver, Inc. (written commun., 1986); Fenix \& Scisson, Inc. (1987b, 1987c); and Nelson and Schimschal (1993).

Well specifications

1. Location and identification:

Latitude and longitude: $36^{\circ} 53^{\prime} 22^{\prime \prime} \mathrm{N}$.; $116^{\circ} 27^{\prime} 35^{\prime \prime} \mathrm{W}$.

Nevada State Central Zone Coordinates (m): N 778,825; E 560,503.

U.S. Geological Survey Site ID: 365322116273501.

2. Drilling and casing information:

Well started: March 25, 1981.

Well completed: October 24, 1981.

Drilling method: Rotary, using rock bits, with polymer mud to $88 \mathrm{~m}$; cored from $88 \mathrm{~m}$ to total depth.

Bit diameter below water level: $222 \mathrm{~mm}$ to $814 \mathrm{~m} ; 159 \mathrm{~mm}$ from $814 \mathrm{~m}$ to $947 \mathrm{~m} ; 156 \mathrm{~mm}$ from 947 to $1,439 \mathrm{~m} ; 76 \mathrm{~mm}$ from $1,439 \mathrm{~m}$ to total depth.

Casing extending below water level: None (surface casing, $320 \mathrm{~mm}$ inside diameter,

0-85 $\mathrm{m}$ and $276 \mathrm{~mm}$ inside diameter, 0-242 $\mathrm{m}$ ).

Total drilled depth: $1,831 \mathrm{~m}$.

3. Access to and description of depth interval for measuring water levels:

Saturated interval of borehole is within the Topopah Spring Tuff of the Paintbrush Group, the Calico Hills Formation, Prow Pass, Bullfrog, and Tram Tuffs of the Crater Flat Group, Lithic Ridge Tuff, and older flows and tuffs.

Bridge plug at a depth of $806 \mathrm{~m}$. Second bridge plug installed in well on September 29,1995. Top of second bridge plug at a depth of $792 \mathrm{~m}$.

Until October 1995, measurements were made through the well casing. On October 3, 1995, a 62-mm insidediameter tubing extending from land surface to $597 \mathrm{~m}$ was installed in well. The bottom of the tube is capped with a 1.5 -m-long well screen above the cap.

4. Information for calculating water-level altitude:

Reference point: Top of metal tag on well casing, altitude 1,553.86 m (surveyed by U.S. Geological Survey, 1984).

Measuring point: Top of casing, $0.034 \mathrm{~m}$ before $2 / 3 / 93,0.332 \mathrm{~m} \mathrm{2/3/93}$ to 10/01/95. Monitoring tube placed in well on October 3, 1995. Measuring point changed to top of monitoring tube. Measuring point after 10/01/95, $0.198 \mathrm{~m}$. All measuring points above reference point.

Depth correction for borehole deviation from vertical: $0.158 \mathrm{~m}$, based on approximate depth to water of $524 \mathrm{~m}$ (1984 data) through 12/31/94. After 01/01/95 depth correction for borehole deviation from vertical: $0.192 \mathrm{~m}$, based on approximate depth to water of $534 \mathrm{~m}$ (1994 data).

5. During 1995, well USW G-2 was instrumented to conduct a single-well aquifer test. Pump failure prevented the test from being conducted and, from October 24 through November 1, 1995, only pretesting pump cycles 
of 10 to 15 minutes, pumping at approximately $0.95 \mathrm{~L} / \mathrm{s}$ were completed. It is estimated that approximately $10 \mathrm{~m}^{3}$ of ground water was pumped from well USW G-2 and maximum drawdown was about $3.5 \mathrm{~m}$ (G.M. O'Brien, U.S. Geological Survey, oral commun., 1996).

Although well USW G-2 was monitored continuously by transducer during October and November 1995, only the manual water-level measurements made during this period are discussed in this report. The decline in water level from October to November (fig. 21) is due to pumpage and slow recovery of water levels in the well. Because of limited access to the well site during 1995, no water-level measurements were made prior to October. Water-level measurements made in well USW G-2 were made with Chain $\# 2$ and Chain \#3 with the following results:

\begin{tabular}{ccc}
\hline Date & $\begin{array}{c}\text { Measured water-level altitude } \\
\text { (meters, above sea level) }\end{array}$ & $\begin{array}{c}\text { Method of measuring } \\
\text { water level }\end{array}$ \\
\hline $10-10-95$ & $1,019.91$ & Chain \#2 \\
$11-02-95$ & $1,019.58$ & Chain \#3 \\
$12-05-95$ & $1,019.74$ & Chain \#3 \\
$12-11-95$ & $1,019.75$ & Chain \#3 \\
\hline
\end{tabular}

Water-level altitudes for well USW G-2 ranged from 1,019.58 to $1,019.91 \mathrm{~m}$ above sea level in 1995 (fig. 21). The mean water-level altitude of the 1995 periodic data was $1,019.74 \mathrm{~m}$ above sea level. This mean altitude was $0.36 \mathrm{~m}$ lower than the mean altitude of $1,020.10 \mathrm{~m}$ for 1994 (Graves and others, 1996). This lower mean water level is due to the pumpage of the well during October and November.

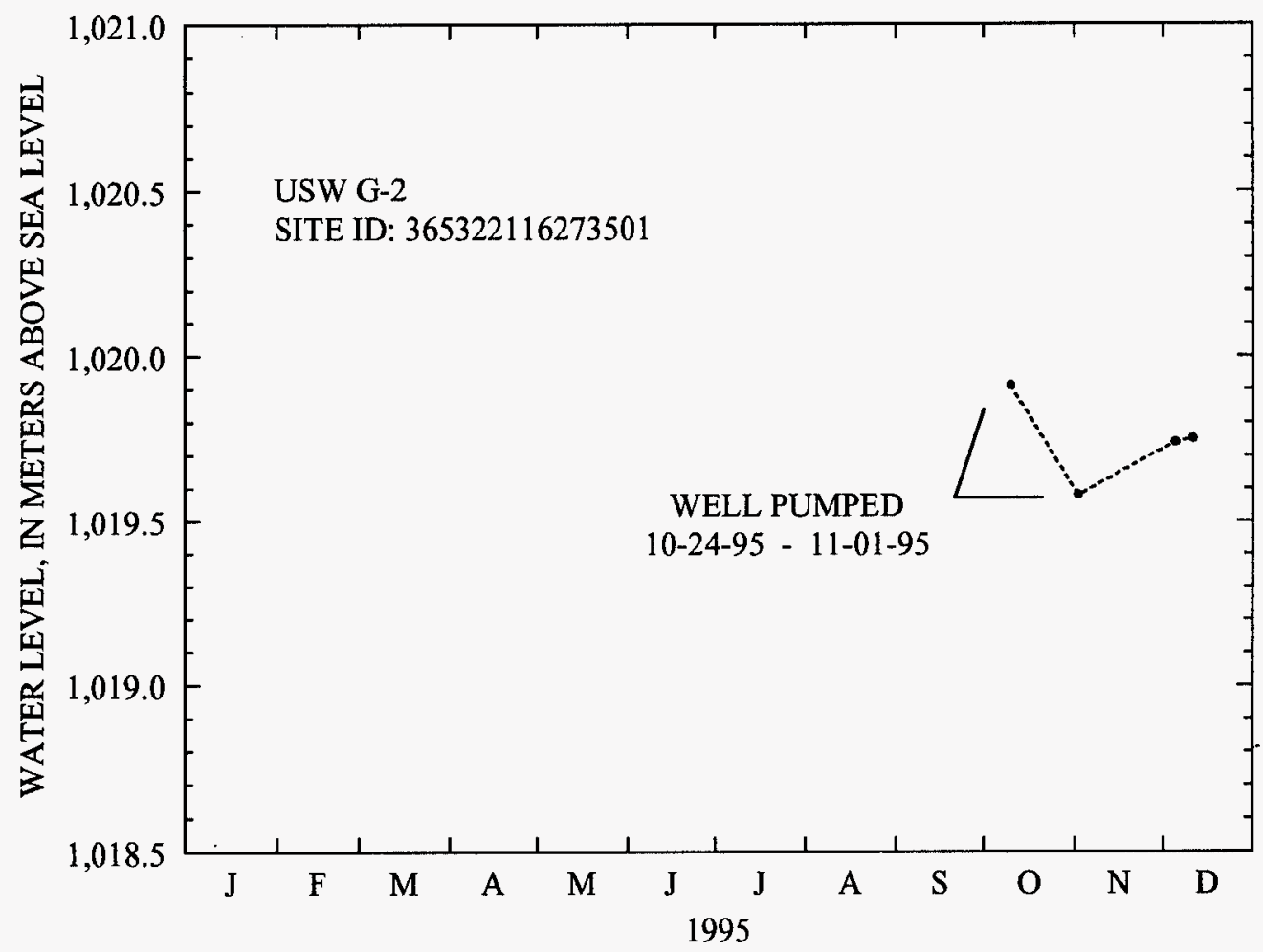

Figure 21. Water-level altitudes, 1995, for well USW G-2. 


\section{Well USW G-3}

Information about the history of well USW G-3 and about previous data from the well was obtained from various sources. These sources are: Robison (1984); Robison (U.S. Geological Survey, written commun., 1986); Robison and others (1988); and Fenix \& Scisson, Inc. (1987b, 1987c).

Well specifications

1. Location and identification:

Latitude and longitude: $36^{\circ} 49^{\prime} 05^{\prime \prime} \mathrm{N}$; $116^{\circ} 28^{\prime} 01^{\prime \prime} \mathrm{W}$.

Nevada State Central Zone Coordinates (m): N 229,447; E 170,226.

U.S. Geological Survey Site ID: 364905116280101.

2. Drilling and casing information:

Well started: January 8, 1982.

Well completed: March 21, 1982.

Drilling method: Rotary, using mostly air-foam, and occasional polymer added for circulating medium; many drilling problems encountered in upper part of borehole, including lost circulation and lost or stuck tools; borehole cored from $795 \mathrm{~m}$ to total drilled depth.

Bit diameter below water level: $222 \mathrm{~mm}$ to $792 \mathrm{~m} ; 121 \mathrm{~mm}$ from 792 to $795 \mathrm{~m} ; 100 \mathrm{~mm}$ from $795 \mathrm{~m}$ to total drilled depth.

Casing extending below water level: $126-\mathrm{mm}$ inside diameter to $792 \mathrm{~m}$; bottom casing back cemented; no perforations.

Total drilled depth: $1,533 \mathrm{~m}$.

3. Access to and description of depth interval for measuring water levels:

Casing, 126-mm inside diameter, extending from land surface to a depth of $792 \mathrm{~m}$; saturated interval of borehole is within the Tram Tuff of the Crater Flat Group and the Lithic Ridge Tuff.

4. Information for calculating water-level altitude:

Reference point: Top of metal tag on well casing; altitude 1,480.47 m (surveyed by U.S. Geological Survey, 1984).

Measuring point: Top of access tube, $0.329 \mathrm{~m}$ above reference point.

Depth correction for borehole deviation from vertical: $0.564 \mathrm{~m}$, based on approximate depth to water of $750 \mathrm{~m}$ (1990 data).

Well USW G-3 was measured periodically during 1995. Water-level measurements in USW G-3 were discontinued after June 1995. Measurements were made with the multiconductor cable unit with the following results:

\begin{tabular}{ccc}
\hline Date & $\begin{array}{c}\text { Measured water-level altitude } \\
\text { (meters, above sea level) }\end{array}$ & $\begin{array}{c}\text { Method of measuring } \\
\text { water level }\end{array}$ \\
\hline $03-15-95$ & 730.74 & Multiconductor cable unit \\
$04-27-95$ & 730.66 & Multiconductor cable unit \\
$06-01-95$ & 730.68 & Multiconductor cable unit \\
$06-27-95$ & 730.49 & Multiconductor cable unit \\
\hline
\end{tabular}


Water-level altitudes for well USW G-3 ranged from 730.49 to $730.68 \mathrm{~m}$ above sea level in 1995 (fig. 22). The mean water-level altitude of the 1995 periodic data was $730.64 \mathrm{~m}$ above sea level. This mean altitude was the same as the mean altitude of $730.64 \mathrm{~m}$ for 1994 (Graves and others, 1996).

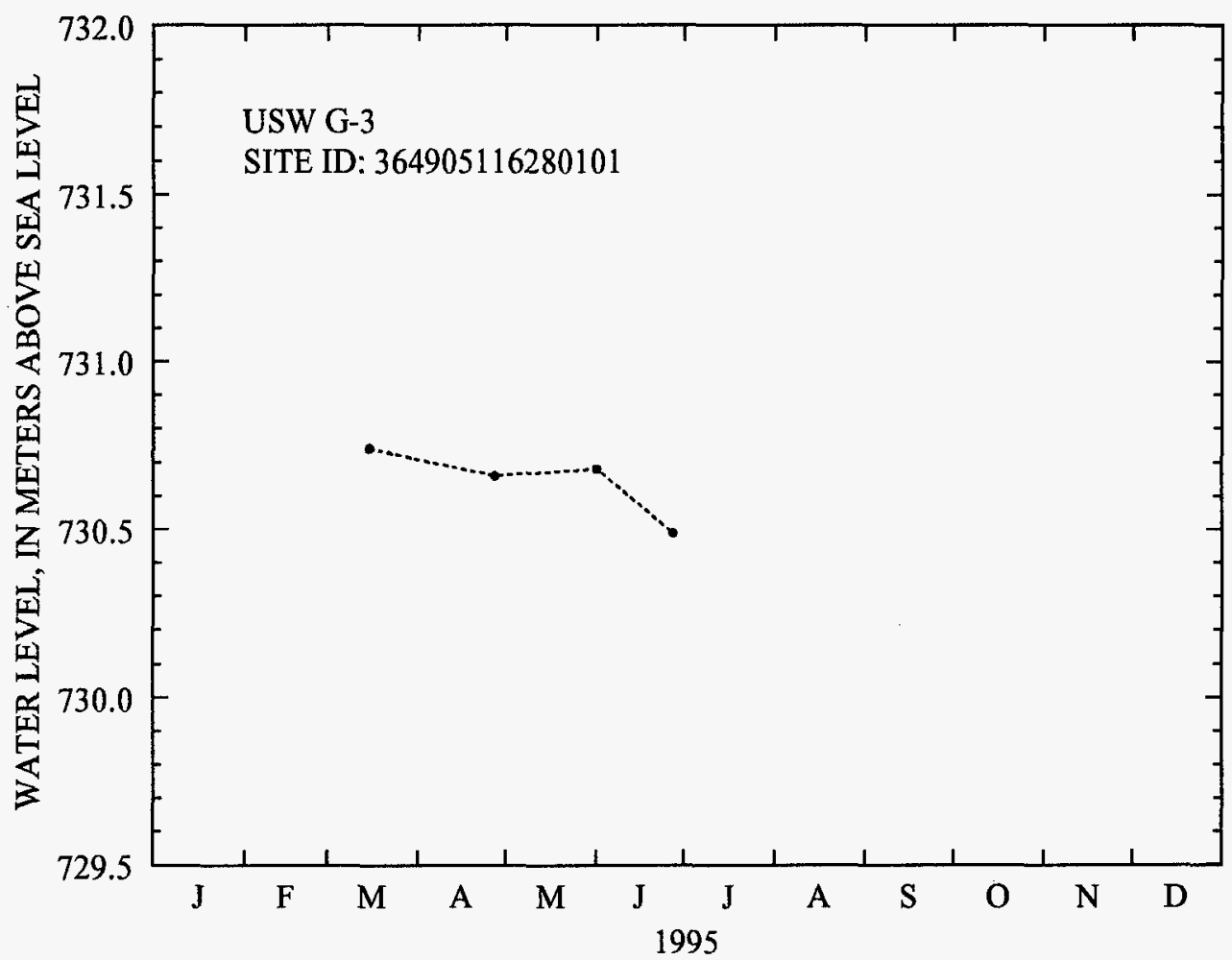

Figure 22. Water-level altitudes, 1995, for well USW G-3.

\section{Well USW H-1}

Information about the history of well USW H-1 and about previous data from the well was obtained from various sources. These sources are: Rush and others (1983); Rush and others (1984); Robison (1984); Robison (U.S. Geological Survey, written commun., 1986); Robison and others (1988); and Fenix \& Scisson, Inc. (1987a, $1987 \mathrm{c})$.

\section{Well specifications}

1. Location and identification:

Latitude and longitude: $36^{\circ} 51^{\prime} 57^{\prime \prime} \mathrm{N}$.; $116^{\circ} 27^{\prime} 12^{\prime \prime} \mathrm{W}$.

Nevada State Central Zone Coordinates (m): N 234,774; E 171,416.

U.S. Geological Survey Site ID: 365157116271201.

2. Drilling and casing information:

Well started: September 3, 1980.

Well completed: January 25, 1981 (initial completion, including geophysical logging and hydraulic testing); July 6, 1982 (recompletion; four piezometers installed). 
Drilling method: Rotary, using rock bits and air-foam circulating medium; cores obtained from selected intervals.

Bit diameter below water level: $311 \mathrm{~mm}$ to $688 \mathrm{~m} ; 222 \mathrm{~mm}$ from $688 \mathrm{~m}$ to $1,829 \mathrm{~m}$.

Casing extending below water level: 226- $\mathrm{mm}$ inside diameter to $687 \mathrm{~m}$. Casing string is tack cemented and perforated below the water table. See section 3 for description of intervals open to water.

Total drilled depth: $1,829 \mathrm{~m}$.

3. Access to and description of depth interval for measuring water levels:

Tube 1:

44-mm inside diameter, that has a 3.6-m-long well screen on bottom, extending from land surface to depth of $1,806 \mathrm{~m}$; responds to depth interval from 1,783 to $1,814 \mathrm{~m}$ within older flows and tuffs beneath the Lithic Ridge Tuff;

Tube 2:

$44 \mathrm{~mm}$ inside diameter, that has a 3.6-m-long well screen on bottom, extending from land surface to depth of $1,115 \mathrm{~m}$; responds to depth interval from 1,097 to $1,123 \mathrm{~m}$ within the Tram Tuff of the Crater Flat Group, and lava flow and flow breccia beneath the Tram Tuff;

\section{Tube 3:}

44- $\mathrm{mm}$ inside diameter, that has a 3.6-m-long well screen on bottom, extending from land surface to depth of $741 \mathrm{~m}$; responds to depth interval from 716 to $765 \mathrm{~m}$ within the Bullfrog Tuff of the Crater Flat Group;

\section{Tube 4:}

62-mm inside diameter, open ended, extending from land surface to depth of $640 \mathrm{~m}$; responds to depth interval from 572 to $673 \mathrm{~m}$ within the Prow Pass Tuff of the Crater Flat Group.

Note: During recompletion, a gravel pack was placed in the vicinity of the well screens for tubes 1, 2, and 3; and other intervals were grouted with cement to ensure that the piezometers are hydraulically isolated from each other.

4. Information for calculating water-level altitude:

Reference point: Top of metal tag on well casing; altitude $1,303.10 \mathrm{~m}$ (surveyed by U.S. Geological Survey, 1984).

Measuring point: Top of access tubes, $0.311 \mathrm{~m}$ above reference point, all intervals.

Depth correction for borehole deviation from vertical: $0.143 \mathrm{~m}$ in tube 1 , based on approximate depth to water of $518 \mathrm{~m}$ (1990 data); $0.171 \mathrm{~m}$ in tube 2, based on approximate depth to water of $567 \mathrm{~m}$ (1993 data); $0.174 \mathrm{~m}$ in tubes 3 and 4, based on approximate depths to water of $572 \mathrm{~m}$ (1990 data).

Tube 1:

Well USW H-1, tube 1 was measured periodically during 1995. Measurements were made with Chain \#3 and Chain \#4 with the following results: 


\begin{tabular}{ccc}
\hline Date & $\begin{array}{c}\text { Measured water-level altitude } \\
\text { (meters, above sea level) }\end{array}$ & $\begin{array}{c}\text { Method of measuring } \\
\text { water level }\end{array}$ \\
\hline $01-26-95$ & 785.86 & Chain \#4 \\
$03-02-95$ & 785.94 & Chain \#3 \\
$03-24-95$ & 785.95 & Chain \#3 \\
$04-11-95$ & 786.01 & Chain \#3 \\
$05-04-95$ & 786.05 & Chain \#3 \\
$06-13-95$ & 786.02 & Chain \#3 \\
$07-12-95$ & 785.99 & Chain \#3 \\
$08-16-95$ & 786.00 & Chain \#3 \\
$09-14-95$ & 786.01 & Chain \#3 \\
$12-05-95$ & 785.91 & Chain \#3 \\
\hline
\end{tabular}

Water-level altitudes for well USW H-1, tube 1 ranged from 785.86 to $786.05 \mathrm{~m}$ above sea level in 1995 (fig. 23). The mean water-level altitude of the 1995 periodic data was $785.97 \mathrm{~m}$ above sea level. This mean altitude was $0.23 \mathrm{~m}$ higher than the mean altitude of $785.74 \mathrm{~m}$ for 1994 (Graves and others, 1996).

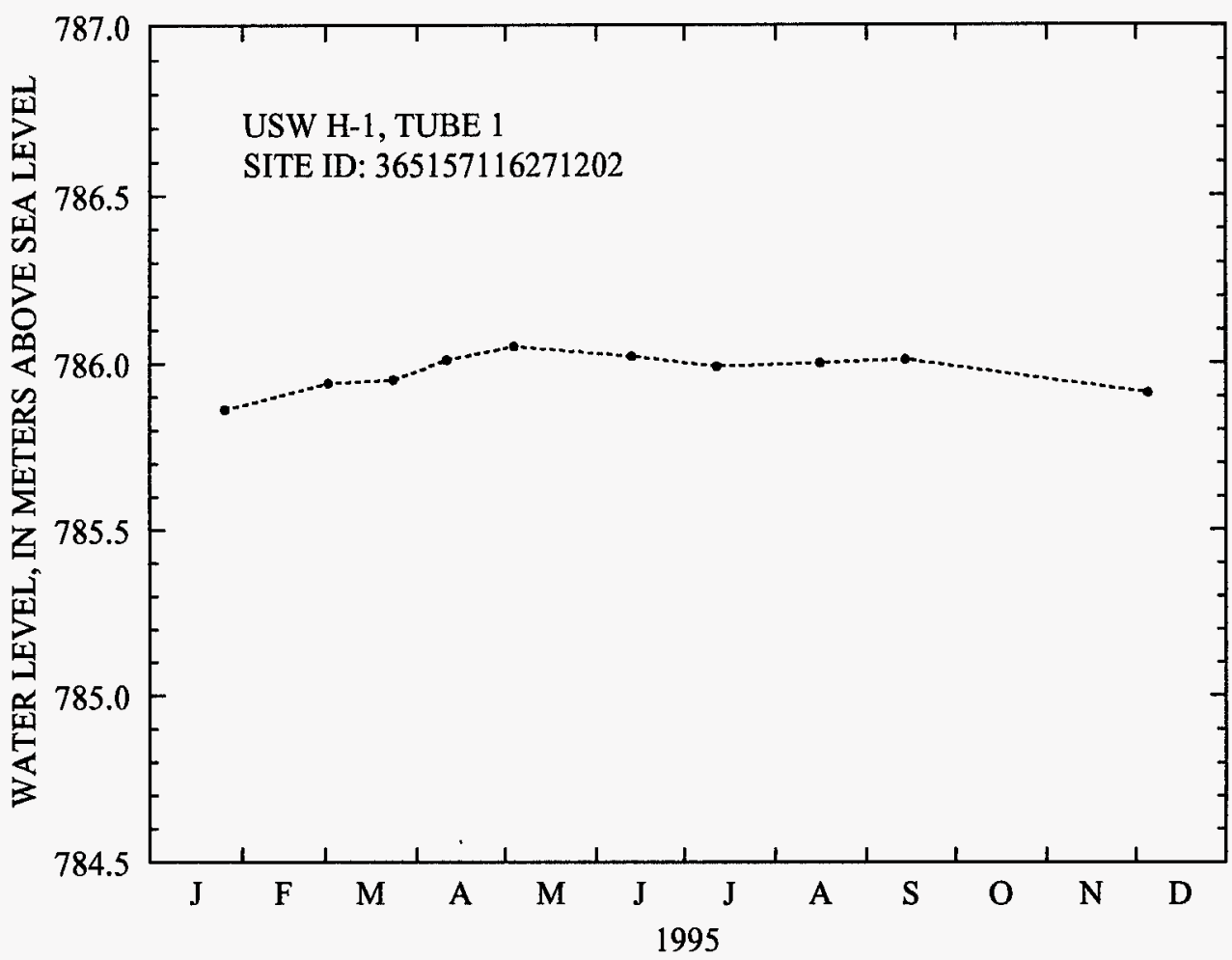

Figure 23. Water-level altitudes, 1995, for well USW H-1, tube 1. 


\section{Tube 2:}

Well USW H-1, tube 2 was measured periodically during 1995. Measurements were made with Chain \#3 and Chain \#4 with the following results:

\begin{tabular}{rcc}
\hline Date & $\begin{array}{c}\text { Measured water-level altitude } \\
\text { (meters, above sea level) }\end{array}$ & $\begin{array}{c}\text { Method of measuring } \\
\text { water level }\end{array}$ \\
\hline $01-26-95$ & 735.70 & Chain \#4 \\
$03-02-95$ & 735.74 & Chain \#3 \\
$03-24-95$ & 735.74 & Chain \#3 \\
$04-11-95$ & 735.78 & Chain \#3 \\
$05-04-95$ & 735.78 & Chain \#3 \\
$06-13-95$ & 735.71 & Chain \#3 \\
$07-12-95$ & 735.77 & Chain \#3 \\
$08-16-95$ & 735.77 & Chain \#3 \\
$09-14-95$ & 735.76 & Chain \#4 \\
$12-05-95$ & 735.67 & Chain \#3 \\
\hline
\end{tabular}

Water-level altitudes for well USW H-1, tube 2 ranged from 735.67 to $735.78 \mathrm{~m}$ above sea level in 1995 (fig. 24). The mean water-level altitude of the 1995 periodic data was $735.74 \mathrm{~m}$ above sea level. This mean altitude was $0.12 \mathrm{~m}$ lower than the mean altitude of $735.86 \mathrm{~m}$ for 1994 (Graves and others, 1996).

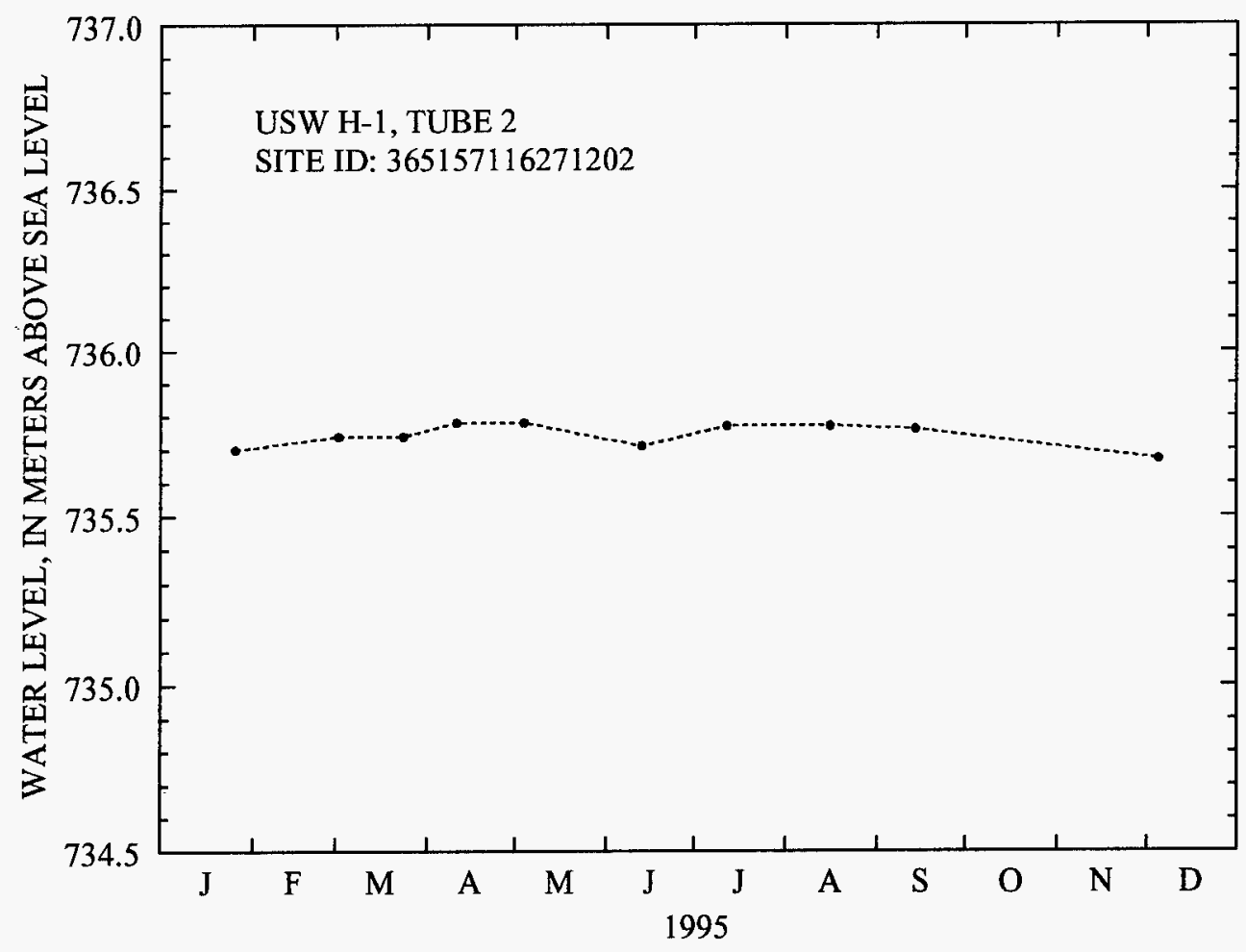

Figure 24. Water-level altitudes, 1995, for well USW H-1, tube 2. 
Tube 3:

Well USW H-1, tube 3 was measured hourly and periodically during 1995 . Hourly measurements were made until September 22, 1995; the day the transducer was removed from the well. During the period of hourly measurements, five calibrations of two transducers were performed. In addition, a calibration was completed on December 20, 1994 to calculate water-level altitudes at the beginning of 1995 . Results of the transducer calibrations are as follows:

\begin{tabular}{cccccc}
\hline $\begin{array}{c}\text { Transducer serial } \\
\text { number }\end{array}$ & $\begin{array}{c}\text { Calibration } \\
\text { date }\end{array}$ & $\begin{array}{c}\text { Slope } \\
\text { (meters/millivolt) }\end{array}$ & $\begin{array}{c}\text { Coefficient of } \\
\text { determination }\end{array}$ & $\begin{array}{c}\text { Water-level } \\
\text { altitude } \\
\text { (meters) }\end{array}$ & $\begin{array}{c}\text { Method of measuring } \\
\text { water level }\end{array}$ \\
\hline 567096 & $12-20-94$ & 0.086 & 0.99 & 730.63 & Chain \#3 \\
567096 & $04-11-95$ & .089 & 0.99 & 730.59 & Tag with transducer \\
567096 & $05-03-95$ & $\begin{array}{c}\text { Failed final } \\
\text { calibration }\end{array}$ & $\begin{array}{c}\text { Failed final } \\
\text { calibration }\end{array}$ & 730.68 & Chain \#3 \\
670688 & $05-03-95$ & .089 & 0.99 & 730.68 & Chain \#3 \\
670688 & $08-30-95$ & .087 & 1.00 & 730.63 & Tag with transducer \\
670688 & $09-22-95$ & .088 & 0.99 & 730.77 & Chain \#3 \\
\hline
\end{tabular}

Partial data were collected from well USW H-1, tube 3 on April 29 and May 3, 1995, and no data were collected from April 30 through May 2, 1995, because of a failed transducer. The transducer was replaced on May 3, 1995. Daily mean water-level altitudes were not calculated for April 29 through May 3, 1995. All other hourly transducer data for 1995 are considered to be valid.

Following the removal of the transducer, well USW H-1, tube 3 was measured periodically during the remainder of 1995 . Measurements were made with Chain \#3 with the following results:

\begin{tabular}{ccc}
\hline Date & $\begin{array}{c}\text { Measured water-level altitude } \\
\text { (meters, above sea level) }\end{array}$ & Method of measuring water level \\
\hline $09-22-95$ & 730.77 & Chain \#3 \\
$12-05-95$ & 730.69 & Chain \#3 \\
\hline
\end{tabular}

Daily mean water-level altitudes of the hourly data for well USW H-1, tube 3 ranged from 730.51 to $730.78 \mathrm{~m}$ above sea level in 1995 (fig. 25). Monthly mean water-level altitudes for January through September 1995, are listed in table 12. The mean water-level altitude of the 1995 hourly data was $730.64 \mathrm{~m}$ above sea level. This mean altitude was $0.06 \mathrm{~m}$ higher than the mean altitude of $730.58 \mathrm{~m}$ for 1994 (Graves and others, 1996). 


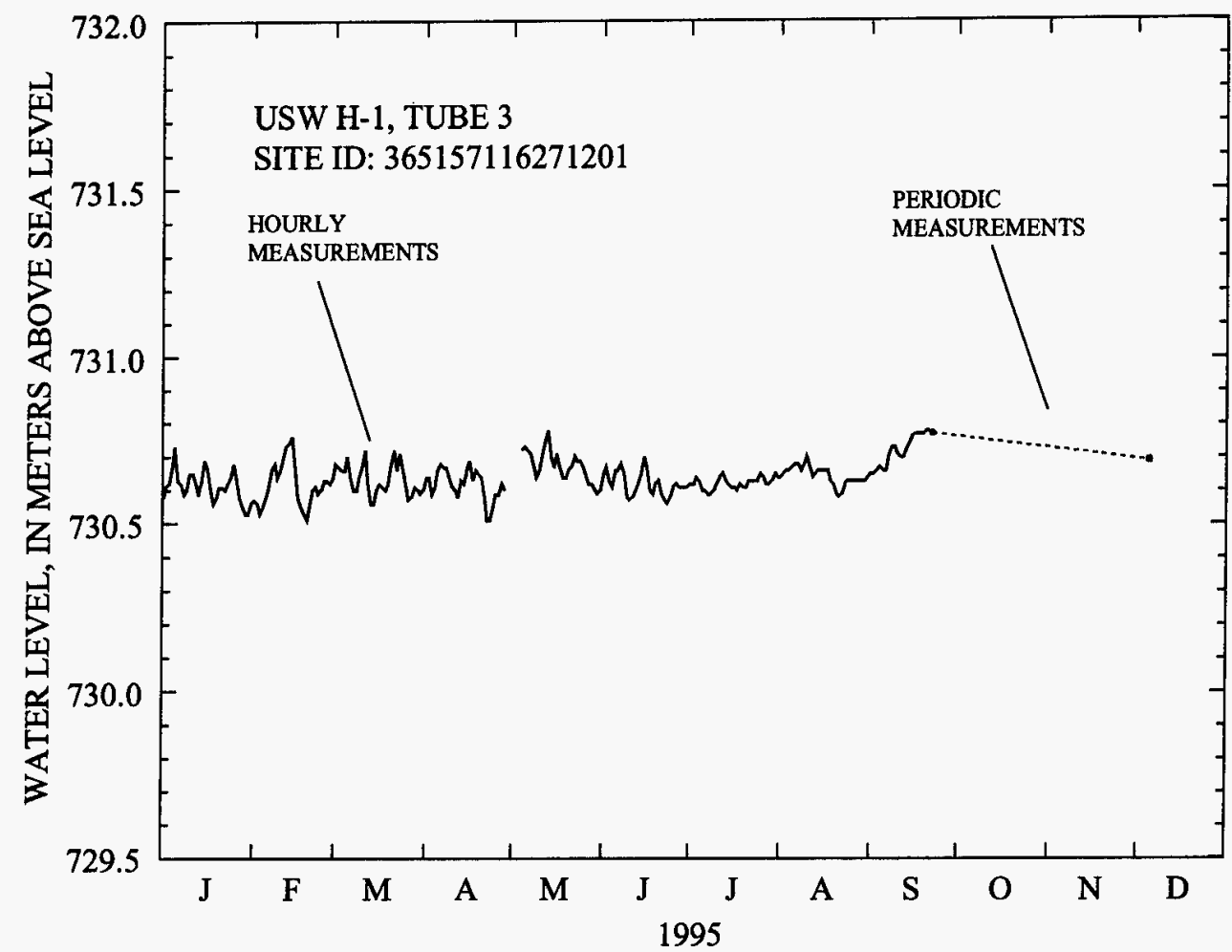

Figure 25. Water-level altitudes, 1995, for well USW H-1, tube 3.

Table 12. Monthly mean water-level altitudes, 1995 , for well USW H-1, tube 3.

[Monthly means were calculated regardless of the number of missing data. Daily means were not calculated if 6 or more consecutive hours of data were missing; --, data not available; NA, not applicable, well not instrumented during this month]

\begin{tabular}{lcc}
\hline Month & $\begin{array}{c}\text { Monthly mean } \\
\text { water-level altitude } \\
\text { (meters, above sea level) }\end{array}$ & $\begin{array}{c}\text { Number of missing daily } \\
\text { means }\end{array}$ \\
\hline January & 730.61 & 0 \\
February & 730.62 & 0 \\
March & 730.63 & 0 \\
April & 730.62 & 2 \\
May & 730.67 & 3 \\
June & 730.62 & 0 \\
July & 730.62 & 0 \\
August & 730.64 & 0 \\
September & 730.72 & 0 \\
October & -- & NA \\
November & - & NA \\
December & - & NA \\
\hline
\end{tabular}




\section{Tube 4:}

Well USW H-1, tube 4 was measured hourly and periodically during 1995 . Hourly measurements were made until September 22, 1995; the day the transducer was removed from the well. During the period of hourly measurements, three calibrations of one transducer were performed. In addition, a calibration was completed on December 12, 1995, to calculate water-level altitudes at the beginning of 1995 . Results of the transducer calibrations are as follows:

\begin{tabular}{cccccc}
\hline $\begin{array}{c}\text { Transducer serial } \\
\text { number }\end{array}$ & $\begin{array}{c}\text { Callbration } \\
\text { date }\end{array}$ & $\begin{array}{c}\text { Slope } \\
\text { (meters/millivolt) }\end{array}$ & $\begin{array}{c}\text { Coefficient of } \\
\text { determination }\end{array}$ & $\begin{array}{c}\text { Water-level } \\
\text { altitude } \\
\text { (meters) }\end{array}$ & $\begin{array}{c}\text { Method of measuring } \\
\text { water level }\end{array}$ \\
\hline 621310 & $12-20-94$ & 0.090 & 1.00 & 730.87 & Tag with transducer \\
621310 & $\mathbf{0 4 - 1 1 - 9 5}$ & .089 & 1.00 & 730.88 & Tag with transducer \\
621310 & $\mathbf{0 7 - 1 1 - 9 5}$ & .089 & 1.00 & 730.88 & Chain \#3 \\
621310 & $\mathbf{0 9 - 2 2 - 9 5}$ & .088 & 1.00 & 730.91 & Chain \#3 \\
\hline
\end{tabular}

Spikes were removed from the data on April 7, and May 27, 1995. The reasons for the spikes are not known. All other hourly transducer data for 1995 are considered to be valid.

Following the removal of the transducer, well USW H-1, tube 4 was measured periodically during the remainder of 1995. Measurements were made with Chain \#3 and the 2,800 foot reference steel tape with the following results:

\begin{tabular}{ccl}
\hline Date & $\begin{array}{c}\text { Measured water-level altitude } \\
\text { (meters, above sea level) }\end{array}$ & Method of measuring water level \\
\hline $09-22-95$ & 730.91 & Chain $\# 3$ \\
$10-25-95$ & 730.88 & 2,800 foot reference steel tape \\
$12-05-95$ & 730.89 & Chain $\# 3$ \\
\hline
\end{tabular}

Daily mean water-level altitudes of the hourly data for well USW H-1, tube 4 ranged from 730.77 to 731.03 $\mathrm{m}$ above sea level in 1995 (fig. 26). Monthly mean water-level altitudes are listed in table 13. The mean waterlevel altitude of the 1995 hourly data was $730.91 \mathrm{~m}$ above sea level. This mean altitude was $0.04 \mathrm{~m}$ higher than the mean altitude of $730.87 \mathrm{~m}$ for 1994 (Graves and others, 1996). 


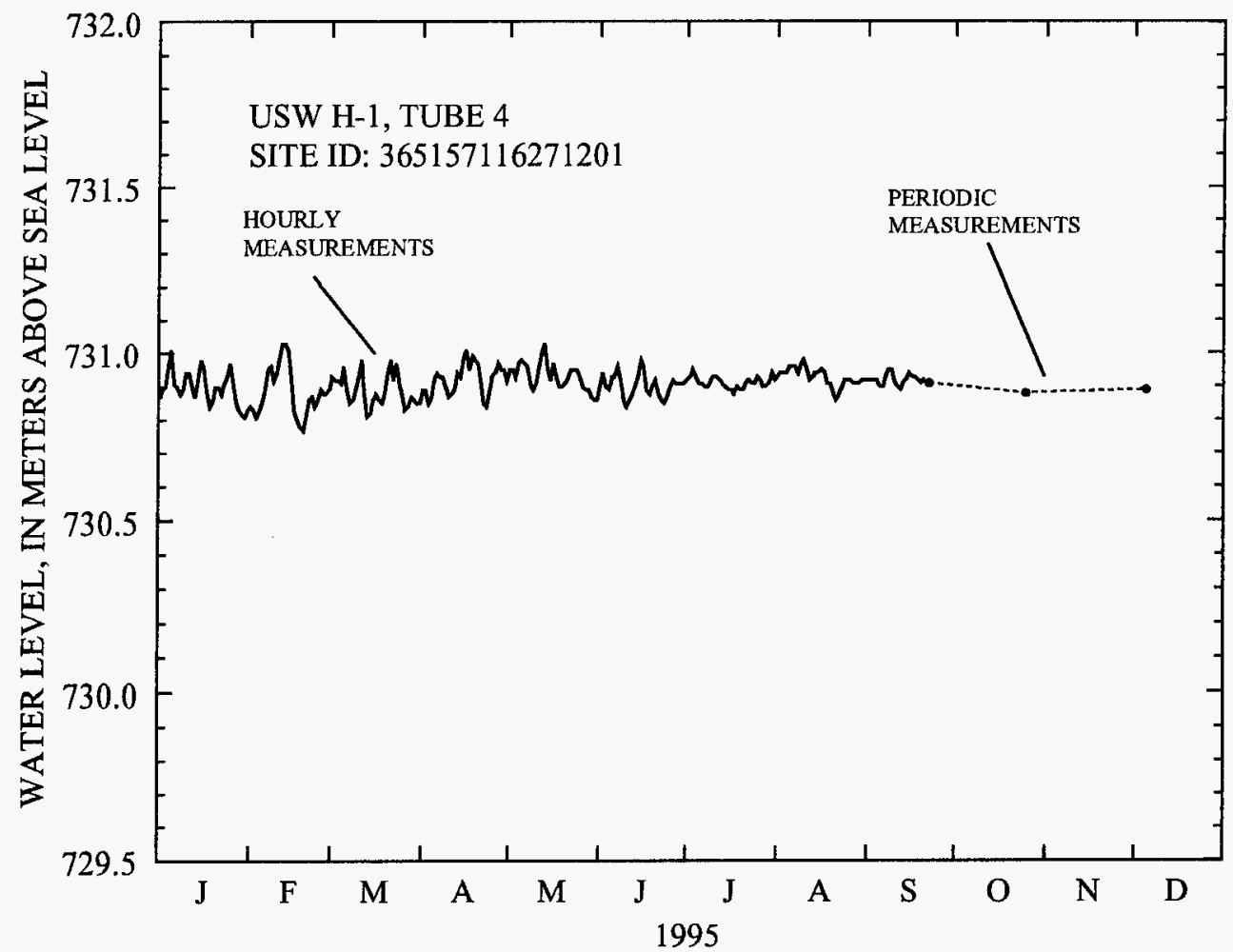

Figure 26. Water-level altitudes, 1995, for well USW H-1, tube 4.

Table 13. Monthly mean water-level altitudes, 1995, for well USW H-1, tube 4.

[Monthly means were calculated regardless of the number of missing data. Daily means were not calculated if 6 or more consecutive hours of data were missing; --, data not available; NA, not applicable, well not instrumented during this month]

\begin{tabular}{lcc}
\hline Month & $\begin{array}{c}\text { Monthly mean } \\
\text { water-level altitude } \\
\text { (meters, above sea level) }\end{array}$ & $\begin{array}{c}\text { Number of missing daily } \\
\text { means }\end{array}$ \\
\hline January & 730.90 & 0 \\
February & 730.88 & 0 \\
March & 730.89 & 0 \\
April & 730.92 & 0 \\
May & 730.93 & 0 \\
June & 730.90 & 0 \\
July & 730.91 & 0 \\
August & 730.93 & 0 \\
September & 730.92 & 0 \\
October & -- & NA \\
November & -- & NA \\
December & -- & NA \\
\hline
\end{tabular}




\section{Well USW H-3}

Information about the history of well USW H-3 and about previous data from the well was obtained from various sources. These sources are: Thordarson, Rush, Spengler, and Waddell (1984); Thordarson, Rush, and Waddell (1984); Robison (1984); Robison (U.S. Geological Survey, written commun., 1986); Robison and others (1988); and Fenix \& Scisson, Inc. (1987a, 1987c).

Well specifications

1. Location and identification:

Latitude and longitude: $36^{\circ} 49^{\prime} 42^{\prime \prime} \mathrm{N} . ; 116^{\circ} 28^{\prime} 00^{\prime \prime} \mathrm{W}$.

Nevada State Central Zone Coordinates (m): N 230,594; E 170,216.

U.S. Geological Survey Site ID: 364942116280001.

2. Drilling and casing information:

Well started: January $27,1982$.

Well completed: March 19, 1982.

Drilling method: Rotary, using rock bits and air-foam circulating medium.

Bit diameter below water level: $375 \mathrm{~mm}$ to $808 \mathrm{~m} ; 222 \mathrm{~m}$ from $808 \mathrm{~m}$ to $1,219 \mathrm{~m}$.

Casing extending below water level: $253 \mathrm{~mm}$ diameter to $792 \mathrm{~m}$, not perforated below the water level.

Total drilled depth: $1,219 \mathrm{~m}$.

3. Access to and description of depth intervals for measuring water levels:

Upper interval:

41-mm inside diameter open ended tubing, extending from land surface to depth of about $762 \mathrm{~m}$; upper interval of well, from near water table to top of inflatable packer, is within bedded tuff and the Tram Tuff of the Crater Flat Group;

Lower interval:

62-mm inside diameter tubing that has an inflatable packer on bottom end extending from land surface to $1,061 \mathrm{~m}$; lower interval from below packer to bottom of well, is within the Tram Member of the Crater Flat Tuff and the Lithic Ridge Tuff.

Note: Inflatable packer installed January 1983 at a depth of $1,190 \mathrm{~m}$; removed late November 1983 during period of additional hydraulic testing; reinstalled during May 1984 at depth of $1,114 \mathrm{~m}$; removed and reinstalled during December 1990 at a depth of $1,061 \mathrm{~m}$.

4. Information for calculating water-level altitude:

Reference point: Top of metal tag on well casing; altitude $1483.47 \mathrm{~m}$ (surveyed by U.S. Geological Survey, 1984).

Measuring point: Top of access tubes, $0.174 \mathrm{~m}$, upper interval; $0.201 \mathrm{~m}$, lower interval. Each measuring point above reference point.

Depth correction for borehole deviation from vertical: $0.079 \mathrm{~m}$, upper interval, based on approximate depth to water of $752 \mathrm{~m}$ (1990 data); $0.058 \mathrm{~m}$, lower interval, based on approximate depth to water of $728 \mathrm{~m}$ (1990 data).

Well USW H-3 upper interval was measured hourly during 1995 . Hourly measurements were made until September 21, 1995; the day the transducer was removed from the well. During the period of hourly 
measurements, three calibrations of one transducer were performed. In addition, a calibration was completed on December 07, 1994, to calculate water-level altitudes at the beginning of 1995. Results of the transducer calibrations are as follows:

\begin{tabular}{cccccc}
\hline $\begin{array}{c}\text { Transducer serial } \\
\text { number }\end{array}$ & $\begin{array}{c}\text { Calibration } \\
\text { date }\end{array}$ & $\begin{array}{c}\text { Slope } \\
\text { (meters/ } \\
\text { millivolt) }\end{array}$ & $\begin{array}{c}\text { Coefficient of } \\
\text { determination }\end{array}$ & $\begin{array}{c}\text { Water-level } \\
\text { altitude } \\
\text { (meters) }\end{array}$ & $\begin{array}{c}\text { Method of measuring water } \\
\text { level }\end{array}$ \\
\hline 621315 & $12-07-94$ & 0.089 & 1.00 & 731.22 & Tag with transducer \\
621315 & $04-20-95$ & .089 & 1.00 & 731.35 & Tag with transducer \\
621315 & $07-26-95$ & .090 & 1.00 & 731.32 & 2,800 foot reference steel tape \\
621315 & $09-21-95$ & .091 & 1.00 & 731.28 & Tag with transducer \\
\hline
\end{tabular}

Partial data were collected on August 8, 1995, because the DCP was off line this date for calibration of the lower interval. A daily mean water-level altitude was not calculated for this date. All other hourly transducer data for 1995 are considered to be valid.

During the September 21, 1995, calibration of well USW H-3 upper interval Chain \#4 broke inside of the monitoring tube blocking access to the water table. This blockage prevented any further water level measurements from being made in the upper interval during 1995.

Daily mean water-level altitudes of the hourly data for well USW H-3 upper interval ranged from 731.15 to $731.42 \mathrm{~m}$ above sea level in 1995 (fig. 27). Monthly mean water-level altitudes for January through September 1995, are listed in table 14. The mean water-level altitude of the1 995 hourly data was $731.29 \mathrm{~m}$ above sea level. This mean altitude was $0.05 \mathrm{~m}$ higher than the mean altitude of $731.24 \mathrm{~m}$ for 1994 (Graves and others, 1996).

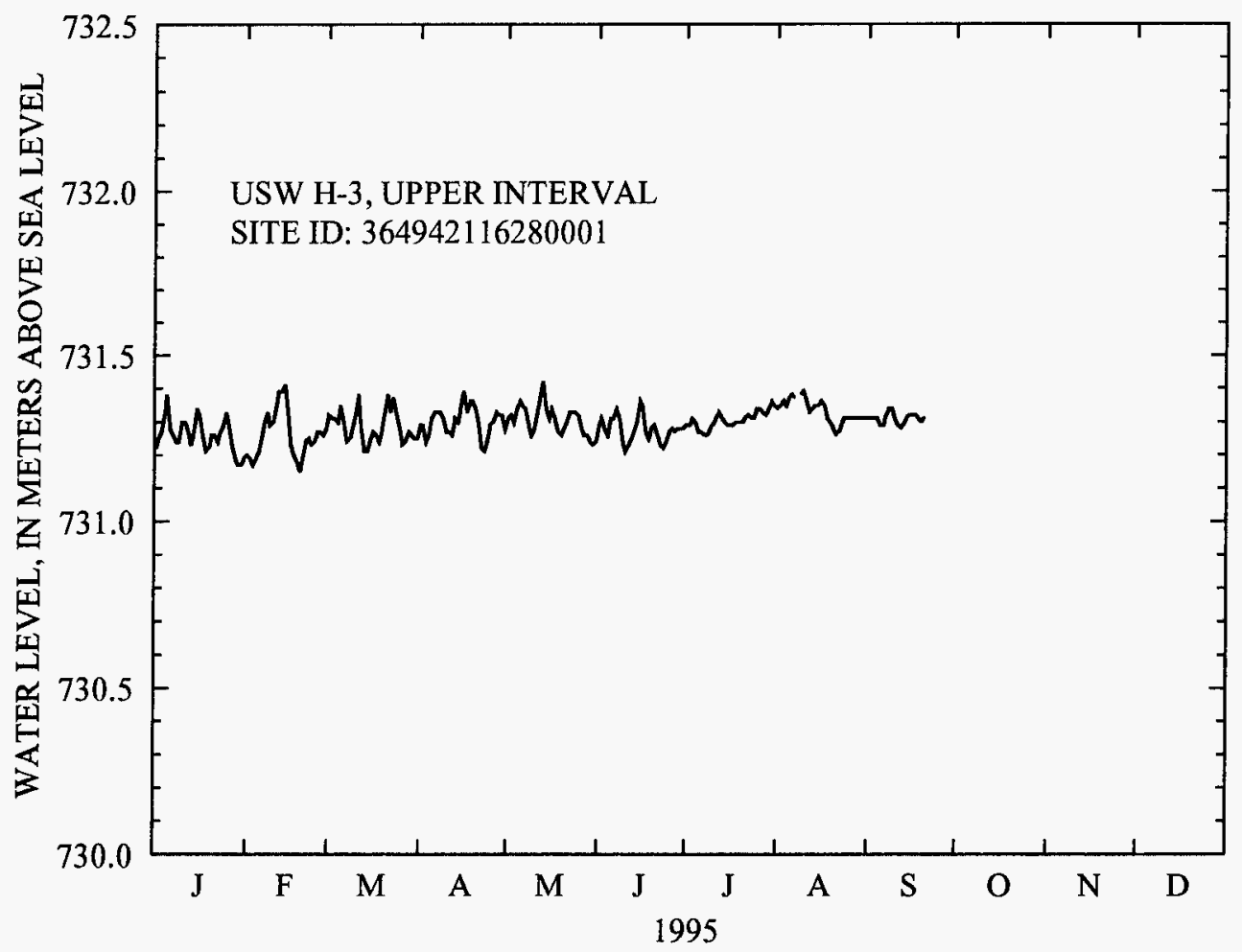

Figure 27. Water-level altitudes, 1995, for well USW H-3, upper interval. 
Table 14. Monthly mean water-level altitudes, 1995, for well USW H-3 upper interval

[Monthly means were calculated regardless of the number of missing data. Daily means were not calculated if 6 or more consecutive hours of data were missing; --, data not available; NA, not applicable, well not instrumented during this month]

\begin{tabular}{lcc}
\hline Month & $\begin{array}{c}\text { Monthly mean } \\
\text { water-level altitude } \\
\text { (meters, above sea level) }\end{array}$ & $\begin{array}{c}\text { Number of missing daily } \\
\text { means }\end{array}$ \\
\hline January & 731.26 & 0 \\
February & 731.26 & 0 \\
March & 731.29 & 0 \\
April & 731.30 & 0 \\
May & 731.31 & 0 \\
June & 731.28 & 0 \\
July & 731.31 & 0 \\
August & 731.33 & 1 \\
September & 731.31 & 0 \\
October & -- & NA \\
November & -- & NA \\
December & -- & NA \\
\hline
\end{tabular}

Well USW H-3 lower interval was measured hourly and periodically during 1995 . Hourly measurements were made until September 21, 1995; the day the transducer was removed from the well. During the period of hourly measurements, four calibrations of one transducer were performed. In addition, a calibration was completed on December 7,1994, to calculate water-level altitudes at the beginning of 1995 . Results of the transducer calibrations are as follows:

\begin{tabular}{cccccl}
\hline $\begin{array}{c}\text { Transducer serial } \\
\text { number }\end{array}$ & $\begin{array}{c}\text { Calibration } \\
\text { date }\end{array}$ & $\begin{array}{c}\text { Slope } \\
\text { (meters/ } \\
\text { millivolt) }\end{array}$ & $\begin{array}{c}\text { Coefficient of } \\
\text { determination }\end{array}$ & $\begin{array}{c}\text { Water-level } \\
\text { altitude } \\
\text { (meters) }\end{array}$ & $\begin{array}{c}\text { Method of measuring water } \\
\text { level }\end{array}$ \\
\hline 621282 & $12-07-94$ & 0.088 & 1.00 & 758.69 & 2,800 foot reference steel tape \\
621282 & $04-20-95$ & .088 & 1.00 & 759.22 & Tag with transducer \\
621282 & $08-08-95$ & .087 & 1.00 & 759.30 & 2,800 foot reference steel tape \\
621282 & $08-09-95$ & .087 & 1.00 & 759.37 & 2,800 foot reference steel tape \\
621282 & $09-21-95$ & .087 & 1.00 & 759.38 & Chain \#3 \\
\hline
\end{tabular}

Partial data were collected on August 8 and 9,1995, two days the well was calibrated. Daily mean waterlevel altitudes were not calculated for these two dates. All other hourly transducer data for 1995 are considered to be valid.

Following the removal of the transducer, well USW H-3 lower interval was measured periodically during the remainder of 1995 . Measurements were made with Chain \#3 and the 2,800 foot reference steel tape with the following results:

\begin{tabular}{ccl}
\hline Date & $\begin{array}{c}\text { Measured water-level altitude } \\
\text { (meters, above sea level) }\end{array}$ & Method of measuring water level \\
\hline $09-21-95$ & 759.38 & Chain \#3 \\
$10-25-95$ & 759.47 & 2,800 foot reference steel tape \\
$12-12-95$ & 759.61 & Chain \#3 \\
\hline
\end{tabular}


Daily mean water-level altitudes of the hourly data for well USW H-3 lower interval ranged from 758.80 to $759.42 \mathrm{~m}$ above sea level in 1995 (fig. 28). This range was extended to $759.61 \mathrm{~m}$ by the manual water-level measurement made on December 12, 1995. Monthly mean water-level altitudes for January through September 1995, are listed in table 15. The mean water-level altitude for 1995 was $759.23 \mathrm{~m}$ above sea level. Because of the significant rising trend of the water level in this well, the 1995 mean was calculated by averaging the January through September monthly mean water-level altitudes with the October and December manual water-level measurements. This mean altitude was $1.05 \mathrm{~m}$ higher than the mean altitude of $758.18 \mathrm{~m}$ for 1994 (Graves and others, 1996). The reason for this significant difference in mean water levels, is because the inflatable packer, which divides the well into two intervals, was moved to a different location on December 14, 1990. Following this move the water level in the lower interval has been rising, in the process of reaching equilibration, to a new static water-level.

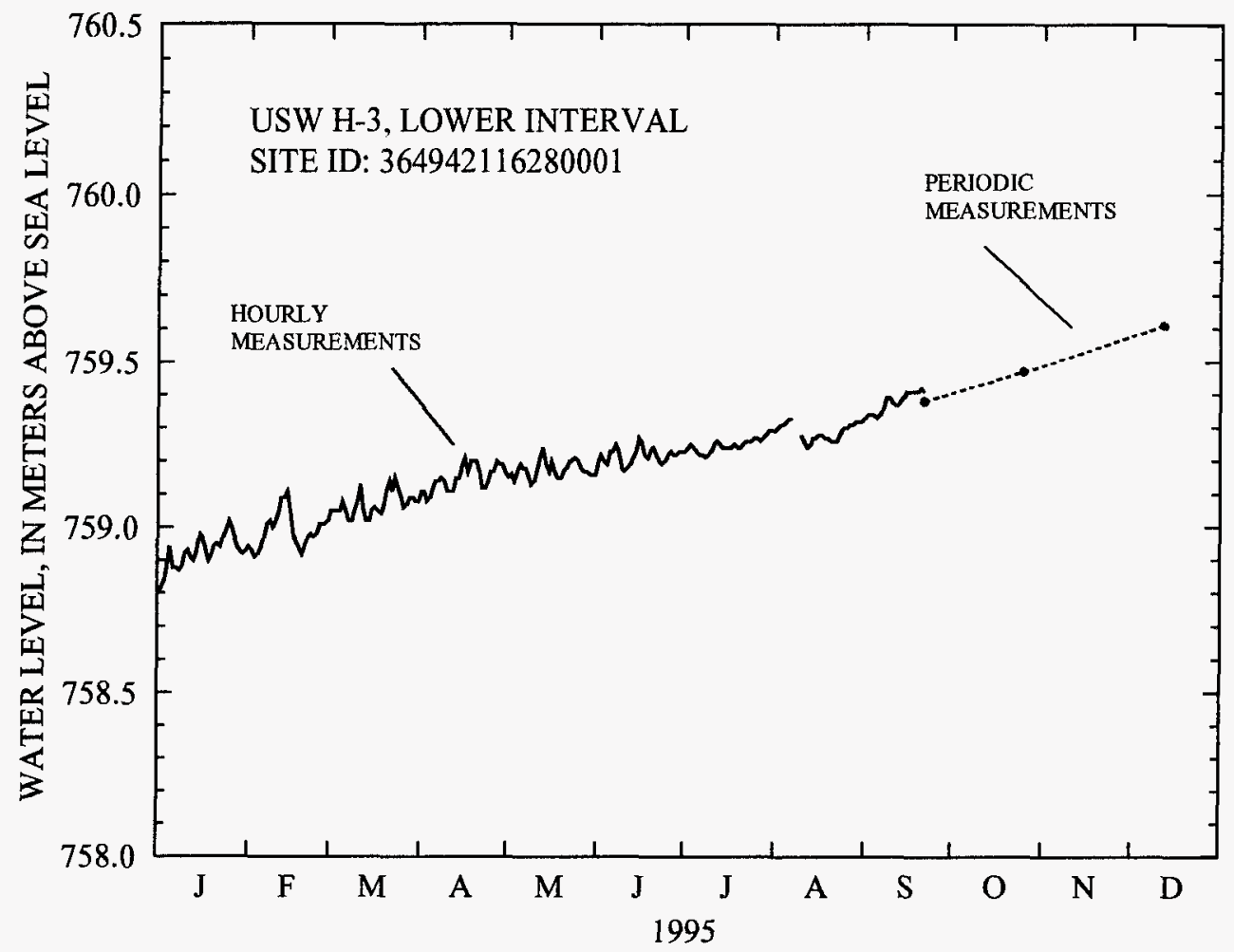

Figure 28. Water-level altitudes, 1995, for well USW H-3, lower interval. 
Table 15. Monthly mean water-level altitudes, 1995, for well USW H-3 lower interval.

[Monthly means were calculated regardless of the number of missing data. Daily means were not calculated if 6 or more consecutive hours of data were missing; --, data not available; NA, not applicable, well not instrumented during this month]

\begin{tabular}{lcc}
\hline Month & $\begin{array}{c}\text { Monthly mean } \\
\text { water-level altitude } \\
\text { (meters, above sea level) }\end{array}$ & $\begin{array}{c}\text { Number of missing dally } \\
\text { means }\end{array}$ \\
\hline January & 758.92 & 0 \\
February & 758.99 & 0 \\
March & 759.07 & 0 \\
April & 759.15 & 0 \\
May & 759.17 & 0 \\
June & 759.22 & 0 \\
July & 759.25 & 0 \\
August & 759.29 & 2 \\
September & 759.38 & 0 \\
October & -- & NA \\
November & -- & NA \\
December & -- & NA \\
\hline
\end{tabular}

\section{Well USW H-4}

Information about the history of well USW H-4 and about previous data from the well was obtained from various sources. These sources are: Whitfield and others (1984); Whitfield and others (1985); Robison (1984); Robison (U.S. Geological Survey, written commun., 1986); Robison and others (1988); Erickson and Waddell (1985); and Fenix \& Scisson, Inc. (1987a, 1987c).

Well specifications

1. Location and identification:

Latitude and longitude: $36^{\circ} 50^{\prime} 32^{\prime \prime N}$.; $116^{\circ} 26^{\prime} 54^{\prime \prime} \mathrm{W}$.

Nevada State Central Zone Coordinates (m): N 232,149; E 171,880.

U.S. Geological Survey Site ID: 365032116265401.

2. Drilling and casing information:

Well started: March 22, 1982.

Well completed: June 7, 1982.

Drilling method: Rotary, using rock bits and air-foam circulating medium; cores obtained from selected intervals.

Bit diameter below water level: $375 \mathrm{~mm}$ to $564 \mathrm{~m} ; 222 \mathrm{~mm}$ from $564 \mathrm{~m}$ to $1,219 \mathrm{~m}$.

Casing extending below water level: $253 \mathrm{~mm}$ diameter to $561 \mathrm{~m}$, perforated below the water level.

Total drilled depth: $1,219 \mathrm{~m}$. 
3. Access to and description of depth interval for measuring water levels:

Upper interval:

48-mm inside diameter open-ended tubing, extending from land surface to depth of $525 \mathrm{~m}$; upper interval of well near water table to top of inflatable packer is within the Prow Pass, Bullfrog, and Tram Tuffs of the Crater Flat Group, bedded tuff, and upper Lithic Ridge Tuff;

\section{Lower interval:}

62-mm inside diameter tubing with inflatable packer on bottom end, extending from land surface to 1,188 $\mathrm{m}$; lower interval of well is within the Lithic Ridge Tuff.

4. Information for calculating water-level altitude:

Reference point: Top of metal tag on well casing; altitude 1,248.74 m (surveyed by U.S. Geological Survey, 1984).

Measuring point: Top of access tubes, $0.597 \mathrm{~m}$, upper interval; $0.308 \mathrm{~m}$, lower interval. Both measuring points above reference point.

Depth correction for borehole deviation from vertical: $0.064 \mathrm{~m}$, based on approximate depth to water of 518 m (1990 data).

Well USW H-4 upper interval was measured hourly and periodically during 1995 . Hourly measurements were made until September 25, 1995; the day the transducer was removed from the well. During the period of hourly measurements, four calibrations of one transducer were performed. In addition, a calibration was completed on November 15, 1994, to calculate water-level altitudes at the beginning of 1995 . Results of the transducer calibrations are as follows:

\begin{tabular}{cccccc}
\hline $\begin{array}{c}\text { Transducer serlal } \\
\text { number }\end{array}$ & $\begin{array}{c}\text { Calibration } \\
\text { date }\end{array}$ & $\begin{array}{c}\text { Slope } \\
\text { (meters/ } \\
\text { millivolt) }\end{array}$ & $\begin{array}{c}\text { Coefficlent of } \\
\text { determination }\end{array}$ & $\begin{array}{c}\text { Water-level } \\
\text { altitude } \\
\text { (meters) }\end{array}$ & $\begin{array}{c}\text { Method of measuring } \\
\text { water level }\end{array}$ \\
\hline 592474 & $11-15-94$ & 0.089 & 1.00 & 730.38 & Tag with transducer \\
592474 & $02-15-95$ & .089 & 1.00 & 730.38 & Chain \#3 \\
592474 & $06-08-95$ & .091 & 1.00 & 730.36 & Tag with transducer \\
592474 & $06-27-95$ & .092 & 1.00 & 730.37 & Tag with transducer \\
592474 & $09-25-95$ & .094 & 1.00 & 730.39 & Chain \#3 \\
\hline
\end{tabular}

Partial data were collected June 7 and 8, 1995, because the transducer was out of the well for calibration these two days. Daily mean water-level altitudes were not calculated for June 7 or 8,1995 . All other hourly transducer data for 1995 are considered to be valid.

Following the removal of the transducer, well USW H-4 upper interval was measured periodically during the remainder of 1995 . Measurements were made with Chain $\# 3$ with the following results:

\begin{tabular}{ccc}
\hline Date & $\begin{array}{c}\text { Measured water-level altitude } \\
\text { (meters, above sea level) }\end{array}$ & Method of measuring water level \\
\hline $09-25-95$ & 730.39 & Chain \#3 \\
$12-12-95$ & 730.41 & Chain \#3 \\
\hline
\end{tabular}

Daily mean water-level altitudes of the hourly data for well USW H-4 upper interval ranged from 730.24 to $730.50 \mathrm{~m}$ above sea level in 1995 (fig. 29). Monthly mean water-level altitudes for January through September 1995 , are listed in table 16 . The mean water-level altitude of the 1995 hourly data was $730.37 \mathrm{~m}$ above sea level. This mean altitude was $0.02 \mathrm{~m}$ lower than the mean altitude of $730.39 \mathrm{~m}$ for 1994 (Graves and others, 1996). 


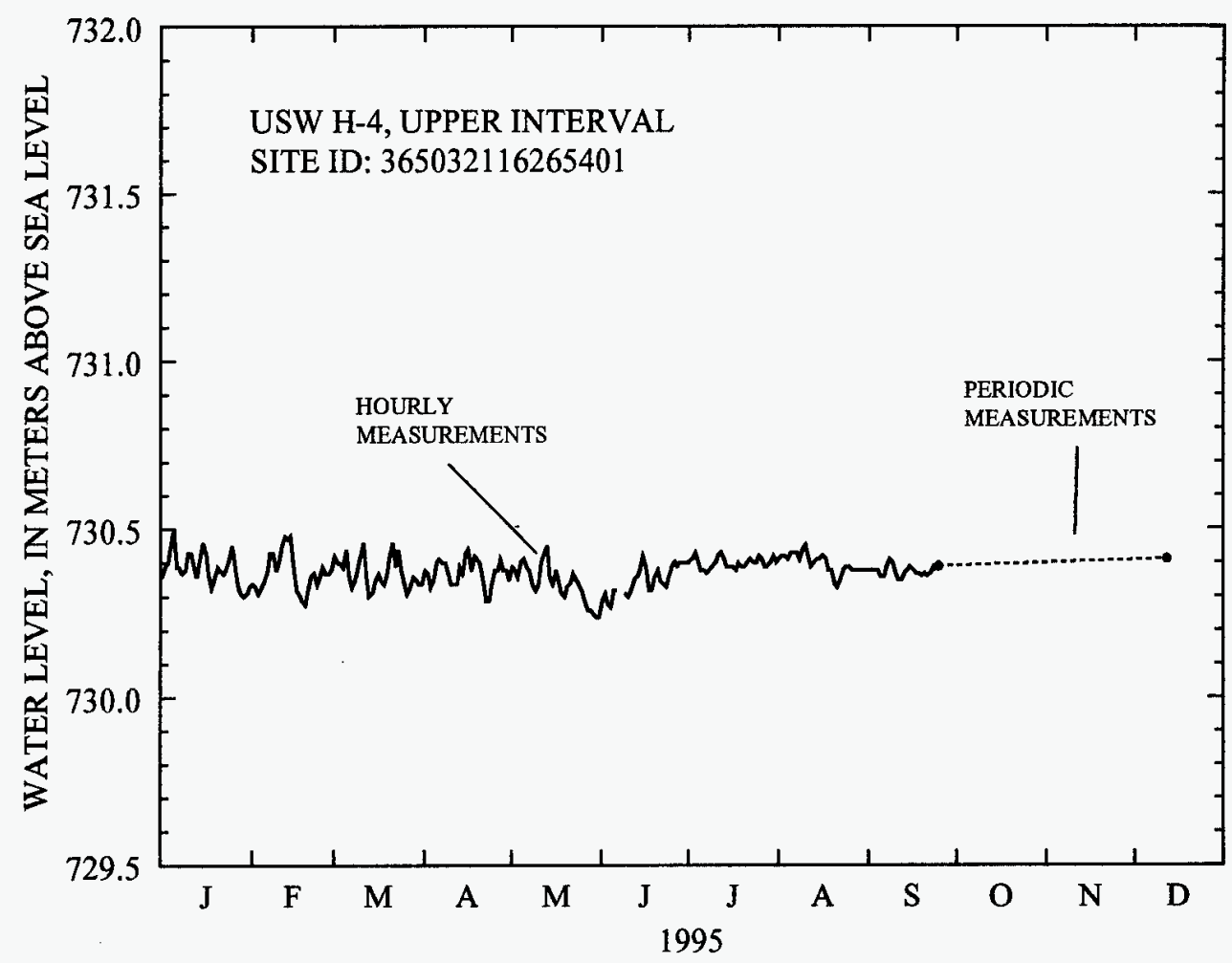

Figure 29. Water-level altitudes, 1995, for well USW H-4, upper interval.

Table 16. Monthly mean water-level altitudes, 1995, for well USW H-4 upper interval.

[Monthly means were calculated regardless of the number of missing data. Daily means were not calculated if 6 or more consecutive hours of data were missing; --, data not available; NA, not applicable, well not instrumented during this month]

\begin{tabular}{lcc}
\hline Month & $\begin{array}{c}\text { Monthly mean } \\
\text { water-level altitude } \\
\text { (meters, above sea level) }\end{array}$ & $\begin{array}{c}\text { Number of missing dally } \\
\text { means }\end{array}$ \\
\hline January & 730.39 & 0 \\
February & 730.37 & 0 \\
March & 730.37 & 0 \\
April & 730.37 & 0 \\
May & 730.34 & 0 \\
June & 730.35 & 2 \\
July & 730.40 & 0 \\
August & 730.40 & 0 \\
September & 730.37 & 0 \\
October & -- & NA \\
November & -- & NA \\
December & -- & NA \\
\hline
\end{tabular}


Well USW H-4 lower interval was measured hourly and periodically during 1995 . Hourly measurements were made until September 25, 1995; the day the transducer was removed from the well. During the period of hourly measurements, four calibrations of two transducers were performed. In addition, a calibration was completed on November 15, 1994, to calculate water-level altitudes at the beginning of 1995. Results of the transducer calibrations are as follows:

\begin{tabular}{cccccc}
\hline $\begin{array}{c}\text { Transducer serial } \\
\text { number }\end{array}$ & $\begin{array}{c}\text { Calibration } \\
\text { date }\end{array}$ & $\begin{array}{c}\text { Slope } \\
\text { (meters/ } \\
\text { millivolt) }\end{array}$ & $\begin{array}{c}\text { Coefficient of } \\
\text { determination }\end{array}$ & $\begin{array}{c}\text { Water-level } \\
\text { altitude } \\
\text { (meters) }\end{array}$ & $\begin{array}{c}\text { Method of measuring } \\
\text { water level }\end{array}$ \\
\hline 567098 & $11-15-94$ & 0.089 & 1.00 & 730.44 & Tag with transducer \\
567098 & $02-15-95$ & .089 & 1.00 & 730.53 & Tag with transducer \\
567098 & $06-07-95$ & .089 & 1.00 & 730.51 & Chain \#3 \\
621287 & $06-08-95$ & .089 & 1.00 & 730.50 & Chain \#3 \\
621287 & $09-25-95$ & .090 & 1.00 & 730.47 & Chain \#3 \\
\hline
\end{tabular}

Partial data were collected on June 7 and 8, 1995, and spikes in the data were removed on May 15, 1995. The transducer was out of the well for calibration for June 7 and 8 and the spikes were due to changing the DCP scan time from 1 to 10 minutes on May 15. Because of the length of time the transducer was out of the well on June 7 and 8, daily mean water-level altitudes were not calculated for either of these two dates. All other hourly transducer data for 1995 are considered to be valid.

Following the removal of the transducer, well USW H-4 lower interval was measured periodically during the remainder of 1995 . Measurements were made with Chain \#3 with the following results:

\begin{tabular}{ccc}
\hline Date & $\begin{array}{c}\text { Measured water-level altitude } \\
\text { (meters, above sea level) }\end{array}$ & Method of measuring water level \\
\hline $09-25-95$ & 730.47 & Chain \#3 \\
$12-12-95$ & 730.52 & Chain \#3 \\
\hline
\end{tabular}

Daily mean water-level altitudes of the hourly data for well USW H-4 lower interval ranged from 730.42 to $730.63 \mathrm{~m}$ above sea level in 1995 (fig. 30). Monthly mean water-level altitudes for January through September 1995, are listed in table 17. The mean water-level altitude of the 1995 hourly data was $730.50 \mathrm{~m}$ above sea level. This mean altitude was $0.01 \mathrm{~m}$ higher than the mean altitude of $730.49 \mathrm{~m}$ for 1994 (Graves and others, 1996). 


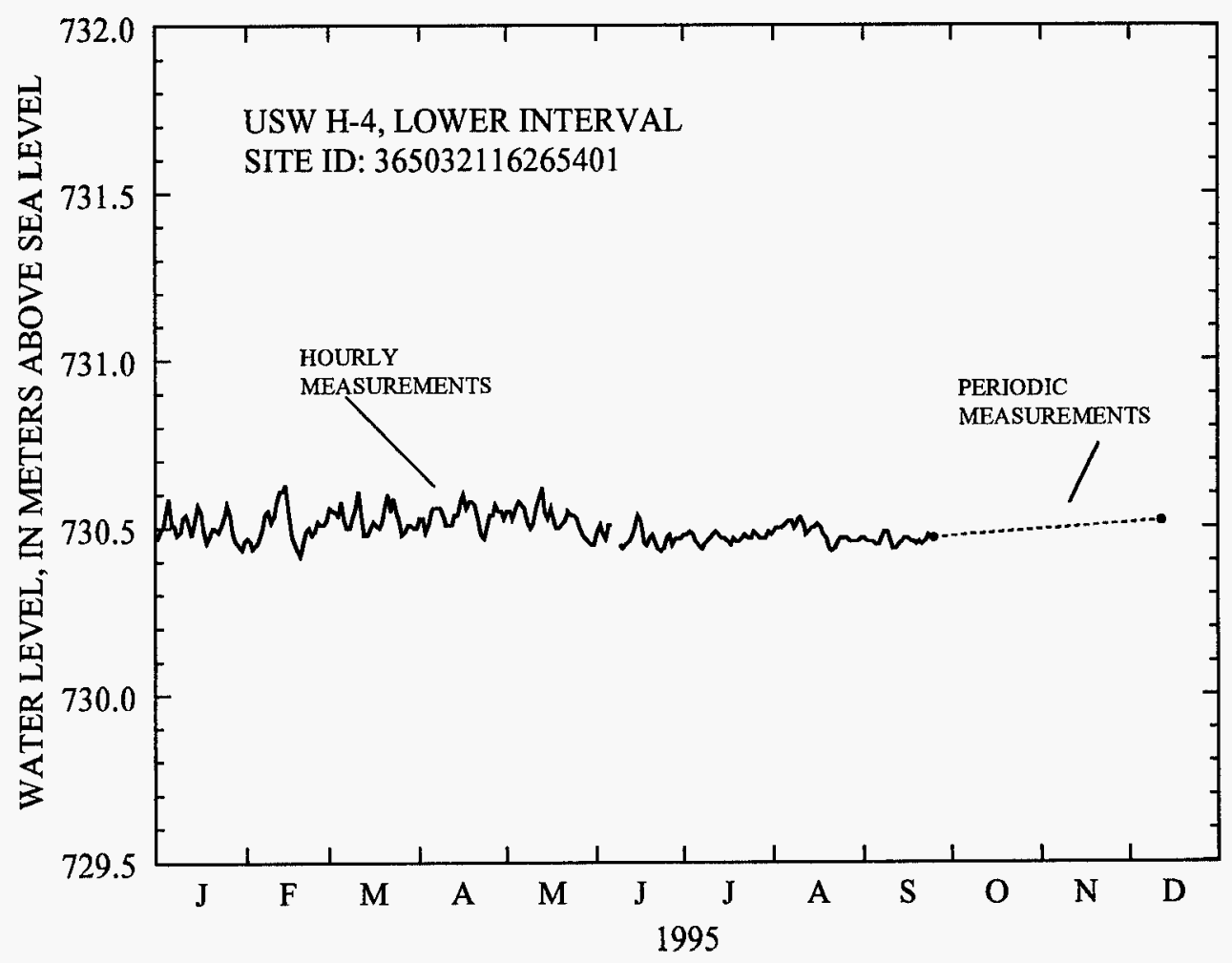

Figure 30. Water-level altitudes, 1995, for well USW H-4, lower interval.

Table 17. Monthly mean water-level altitudes, 1995 , for well USW H-4 lower interval.

[Monthly means were calculated regardless of the number of missing data. Daily means were not calculated if 6 or more consecutive hours of data were missing; --, data not available; NA, not applicable, well not instrumented during this month]

\begin{tabular}{lcc}
\hline Month & $\begin{array}{c}\text { Monthly mean } \\
\text { water-level altitude } \\
\text { (meters, above sea level) }\end{array}$ & $\begin{array}{c}\text { Number of missing daily } \\
\text { means }\end{array}$ \\
\hline January & 730.51 & 0 \\
February & 730.51 & 0 \\
March & 730.53 & 0 \\
April & 730.54 & 0 \\
May & 730.53 & 0 \\
June & 730.47 & 2 \\
July & 730.47 & 0 \\
August & 730.48 & 0 \\
September & 730.46 & 0 \\
October & -- & NA \\
November & -- & NA \\
December & -- & NA \\
\hline
\end{tabular}




\section{Well USW H-5}

Information about the history of well USW H-5 and about previous data from the well was obtained from various sources. These sources are: Bentley and others (1983); Robison (1984); Robison (U.S. Geological Survey, written commun., 1986); Robison and others (1988); Fenix \& Scisson, Inc. (1987a, 1987c); Carr (1988, p. 37); and Sawyer and others (1994, p. 1305).

Well specifications

1. Location and identification:

Latitude and longitude: $36^{\circ} 51^{\prime} 22^{\prime \prime} \mathrm{N}$; $116^{\circ} 27^{\prime} 55^{\prime \prime} \mathrm{W}$.

Nevada State Central Zone Coordinates (m): N 233,670; E 170,355.

U.S. Geological Survey Site ID: 365122116275502.

2. Drilling and casing information:

Well started: May 19, 1982.

Well completed: August 1, 1982.

Drilling method: Rotary, using rock bits and air-foam circulating medium; cores obtained from selected intervals.

Bit diameter below water level: $375 \mathrm{~mm}$ to $792 \mathrm{~m} ; 222 \mathrm{~mm}$ from $792 \mathrm{~m}$ to $1,219 \mathrm{~m}$.

Casing extending below water level: $255 \mathrm{~mm}$ diameter to $788 \mathrm{~m}$, perforated below the water level.

Total drilled depth: $1,219 \mathrm{~m}$.

3. Access to and description of depth interval for measuring water levels:

\section{Upper interval:}

48-mm inside-diameter open-ended tubing, extending from land surface to a depth of $709 \mathrm{~m}$; upper saturated interval of the borehole is within the Bullfrog and Tram Tuffs of the Crater Flat Group, bedded tuff, and unnamed lava beneath the Tram Tuff.

\section{Lower interval:}

62-mm inside-diameter tubing that has a 3.6-m-long inflatable packer on bottom end, extending from land surface to $846 \mathrm{~m}$; lower interval is within the Tram Tuff of the Crater Flat Group, and within an unnamed lava unit below the Tram Tuff.

Note: The packer was reset at its present depth $(846 \mathrm{~m})$ on $3 / 25 / 93$, from its previous depth of $1,091 \mathrm{~m}$ (G.M. O’Brien, U.S. Geological Survey, written commun., 1993).

4. Information for calculating water-level altitude:

Reference point: Top of metal tag on well casing; altitude 1,478.94 m (surveyed by U.S. Geological Survey, 1984).

Measuring point: Top of access tubes, $0.329 \mathrm{~m}$, upper interval; $0.235 \mathrm{~m}$, lower interval. Both measuring points above the reference point.

Depth correction for borehole deviation from vertical: $0.079 \mathrm{~m}$, based on approximate depth to water of $703 \mathrm{~m}$ (1990 data).

Well USW H-5 upper interval was measured hourly during all of 1995. During 1995 three calibrations of one transducer were performed. In addition, calibrations completed on October 14, 1994, and June 4, 1996, were used to calculate water levels for 1995. Results of the transducer calibrations are as follows: 


\begin{tabular}{cccccc}
\hline $\begin{array}{c}\text { Transducer serial } \\
\text { number }\end{array}$ & $\begin{array}{c}\text { Calibration } \\
\text { date }\end{array}$ & $\begin{array}{c}\text { Slope } \\
\text { (meters/ } \\
\text { millivolt) }\end{array}$ & $\begin{array}{c}\text { Coefficient of } \\
\text { determination }\end{array}$ & $\begin{array}{c}\text { Water-level } \\
\text { altitude } \\
\text { (meters) }\end{array}$ & $\begin{array}{c}\text { Method of measuring } \\
\text { water level }\end{array}$ \\
\hline 570799 & $10-14-94$ & 0.088 & 1.00 & 775.59 & Tag with transducer \\
570799 & $02-07-95$ & .089 & 1.00 & 775.46 & Chain \#3 \\
570799 & $06-19-95$ & .089 & 1.00 & 775.38 & Tag with transducer \\
570799 & $12-18-95$ & .089 & 1.00 & 775.40 & Tag with transducer \\
570799 & $06-04-96$ & .088 & 1.00 & 775.44 & Chain \#3 \\
\hline
\end{tabular}

No data were collected for this well from October 19, through December 31, 1995. The data were lost because of wiring problems caused by the removal of a barometer which was hooked into well USW H-5's data collector. Partial data were collected June 14, 1995, because the DCP was off line for calibration of the lower interval. Spikes were removed from the data on February 7 and June 19, 1995. The spikes were due to the calibration of the transducer these two days. A spike was also removed from the data on October 9, 1995. The reason for the spike is not known. Daily mean water-level altitudes were not calculated for February 7, June 14, or October 19 through December 31, 1995. All other hourly transducer data for 1995 are considered to be valid.

Daily mean water-level altitudes of the hourly data for well USW H-5 upper interval ranged from 775.31 to $775.57 \mathrm{~m}$ above sea level in 1995 (fig. 31). Monthly mean water-level altitudes for 1995, are listed in table 18 . The mean water-level altitude of the 1995 hourly data was $775.40 \mathrm{~m}$ above sea level. This mean altitude was 0.08 $\mathrm{m}$ lower than the mean altitude of $775.48 \mathrm{~m}$ for 1994 (Graves and others, 1996).

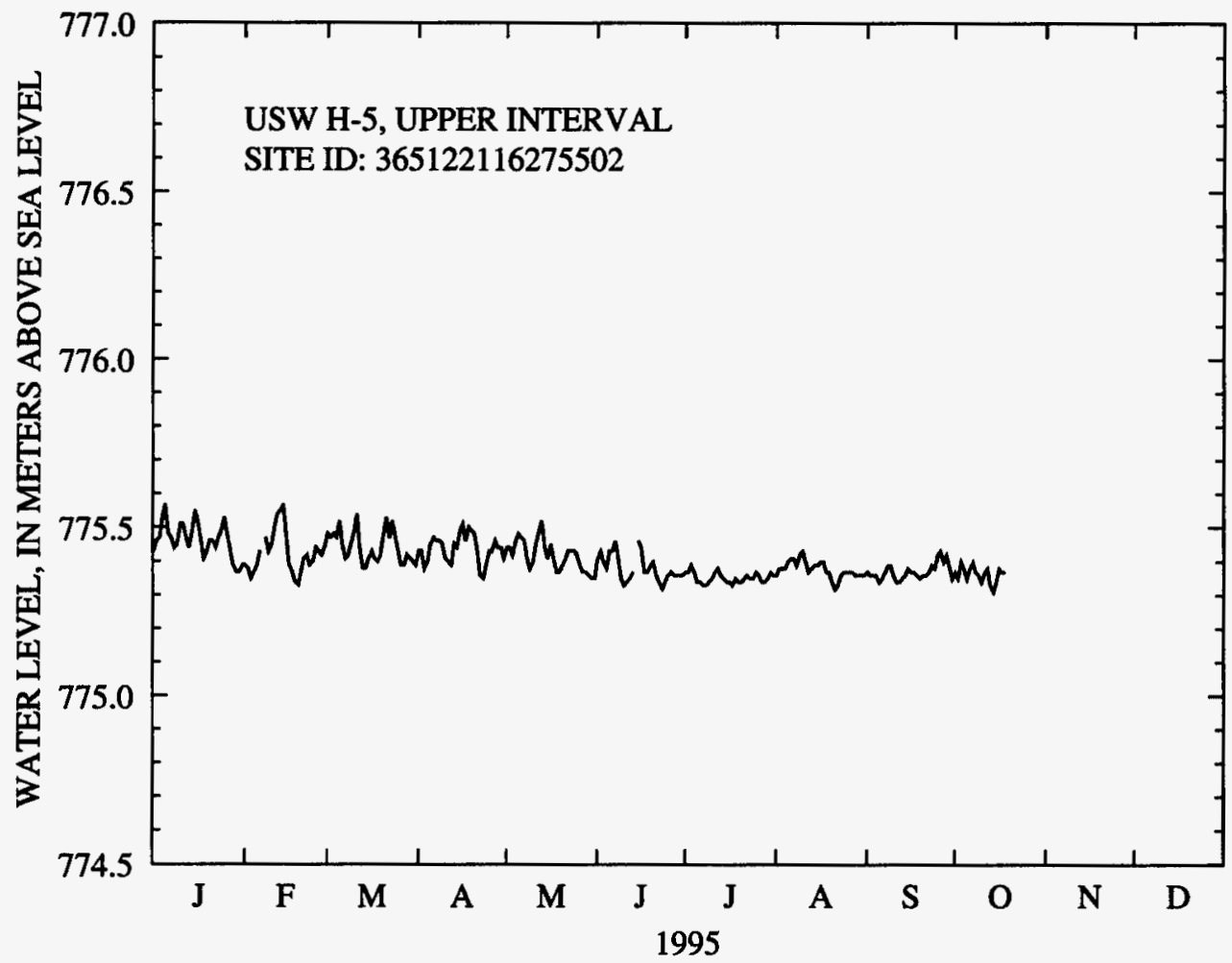

Figure 31. Water-level altitudes, 1995, for well USW H-5, upper interval. 
Table 18. Monthly mean water-level altitudes, 1995 , for well USW H-5 upper interval

[Monthly means were calculated regardless of the number of missing data. Daily means were not calculated if 6 or more consecutive hours of data were missing; --, data not available]

\begin{tabular}{ccc}
\hline Month & $\begin{array}{c}\text { Monthly mean } \\
\text { water-level altitude } \\
\text { (meters, above sea level) }\end{array}$ & $\begin{array}{c}\text { Number of missing daily } \\
\text { means }\end{array}$ \\
\hline January & 775.46 & 0 \\
February & 775.42 & 1 \\
March & 775.44 & 0 \\
April & 775.44 & 0 \\
May & 775.42 & 0 \\
June & 775.38 & 1 \\
July & 775.35 & 0 \\
August & 775.38 & 0 \\
September & 775.37 & 0 \\
October & 775.36 & 13 \\
November & -- & 30 \\
December & -- & 31 \\
\hline
\end{tabular}

Well USW H-5 lower interval was measured hourly during all of 1995. During 1995 four calibrations of two transducers were performed. In addition, calibrations completed on October 14, 1994, and June 5, 1996, were used to calculate water levels for 1995. Results of the transducer calibrations are as follows:

\begin{tabular}{cccccc}
\hline $\begin{array}{c}\text { Transducer serial } \\
\text { number }\end{array}$ & $\begin{array}{c}\text { Calibration } \\
\text { date }\end{array}$ & $\begin{array}{c}\text { Slope } \\
\text { (meters/ } \\
\text { mlllivolt) }\end{array}$ & $\begin{array}{c}\text { Coefficient of } \\
\text { determination }\end{array}$ & $\begin{array}{c}\text { Water-level } \\
\text { altitude } \\
\text { (meters) }\end{array}$ & $\begin{array}{c}\text { Method of measuring } \\
\text { water level }\end{array}$ \\
\hline 525611 & $10-14-94$ & 0.356 & 1.00 & 775.79 & Tag with transducer \\
525611 & $02-08-95$ & .353 & 1.00 & 775.74 & Chain \#3 \\
525611 & $06-14-95$ & .354 & 1.00 & 775.73 & Chain \#3 \\
631046 & $06-14-95$ & .355 & 1.00 & 775.73 & Chain \#3 \\
631046 & $12-19-95$ & .376 & 0.99 & 775.76 & Tag with transducer \\
631046 & $06-05-96$ & .356 & 1.00 & 775.71 & Chain \#3 \\
\hline
\end{tabular}

No data were collected for this well from October 20, through December 31, 1995. The data were lost because of wiring problems caused by the removal of a barometer which was hooked into well USW H-5's data collector. Partial data were collected June 14, 1995, because the DCP was off line for calibration of the lower interval. Partial data were also collected on October 19, 1995, the first day of wiring problems. A spike was removed from the data on October 9, 1995. The reason for the spike is not known. A daily mean value was not collected for January 1, 1995, because the 2400 reading of the previous day, December 31, 1994, was removed. Daily mean water-level altitudes were also not calculated for June 14 or for October 19 through December 31, 1995. All other hourly transducer data for 1995 are considered to be valid.

Daily mean water-level altitudes of the hourly data for well USW H-5 lower interval ranged from 775.60 to $775.98 \mathrm{~m}$ above sea level in 1995 (fig. 32). Monthly mean water-level altitudes for 1995, are listed in table 19. The mean water-level altitude of the 1995 hourly data was $775.78 \mathrm{~m}$ above sea level. This mean altitude was $0.13 \mathrm{~m}$ higher than the mean altitude of $775.65 \mathrm{~m}$ for 1994 (Graves and others, 1996). 


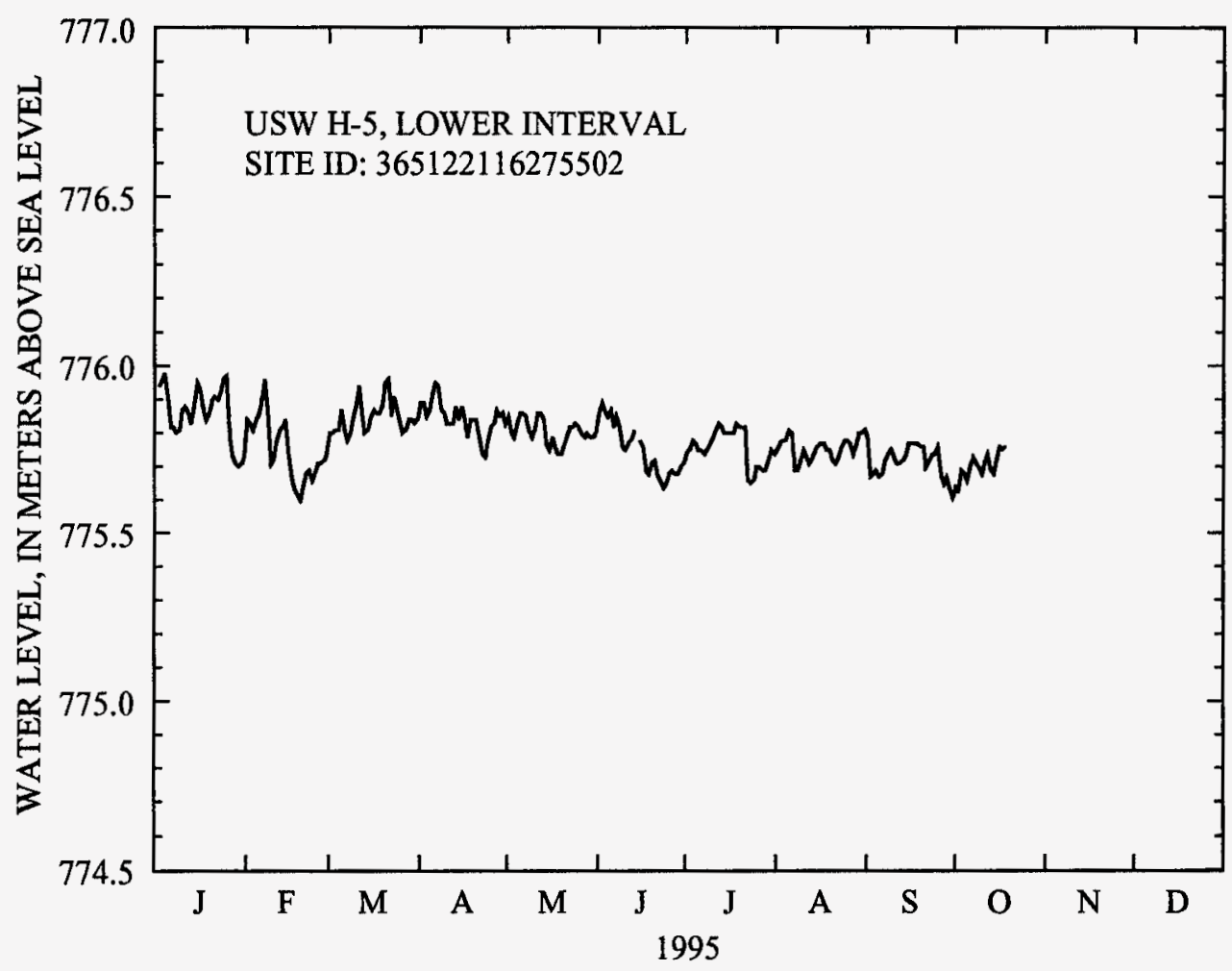

Figure 32. Water-level altitudes, 1995, for well USW H-5, lower interval.

Table 19. Monthly mean water-level altitudes, 1995 , for well USW H-5 lower interval.

[Monthly means were calculated regardless of the number of missing data. Daily means were not calculated if 6 or more consecutive hours of data were missing; --, data not available]

\begin{tabular}{lcc}
\hline Month & $\begin{array}{c}\text { Monthly mean } \\
\text { water-level altitude } \\
\text { (meters, above sea level) }\end{array}$ & $\begin{array}{c}\text { Number of mlssing dally } \\
\text { means }\end{array}$ \\
\hline January & 775.86 & 1 \\
February & 775.75 & 0 \\
March & 775.85 & 0 \\
April & 775.85 & 0 \\
May & 775.81 & 0 \\
June & 775.75 & 1 \\
July & 775.76 & 0 \\
August & 775.76 & 0 \\
September & 775.72 & 0 \\
October & 775.70 & 13 \\
November & -- & 30 \\
December & -- & 31 \\
\hline
\end{tabular}




\section{Well USW H-6}

Information about the history of well USW H-6 and about previous data from the well was obtained from various sources. These sources are: Craig and others (1983); Robison (1984); Robison (U.S. Geological Survey, written commun., 1986); Robison and others (1988); and Fenix \& Scisson, Inc. (1987a, 1987c).

Well specifications

1. Location and identification:

Latitude and longitude: $36^{\circ} 50^{\prime} 49^{\prime \prime} \mathrm{N}$.; $116^{\circ} 28^{\prime} 55^{\prime \prime} \mathrm{W}$.

Nevada State Central Zone Coordinates (m): N 232,654; E 168,882.

U.S. Geological Survey Site ID: 365049116285501.

2. Drilling and casing information:

Well started: August 7,1982.

Well completed: October 28, 1982.

Drilling method: Rotary, using rock bits and air-foam circulating medium; cores obtained from selected intervals.

Bit diameter below water level: $375 \mathrm{~mm}$ to $583 \mathrm{~m} ; 222 \mathrm{~mm}$ from 583 to $1,216 \mathrm{~m} ; 156 \mathrm{~mm}$ from $1,216 \mathrm{~m}$ to $1,220 \mathrm{~m}$.

Casing extending below water level: $250-\mathrm{mm}$ diameter to $581 \mathrm{~m}$, perforated below the water level.

Total drilled depth: $1,220 \mathrm{~m}$.

3. Access to and description of depth interval for measuring water levels:

\section{Upper interval:}

48-mm inside diameter open-ended tubing, extending from land surface to $533 \mathrm{~m}$; saturated upper interval is within the Prow Pass, Bullfrog, and Tram Tuffs of the Crater Flat Group, and bedded tuff;

\section{Lower interval:}

62-mm inside diameter tubing with inflatable packer on bottom end, extending from land surface to $752 \mathrm{~m}$; lower interval is within the Tram Tuff of the Crater Flat Group, bedded tuff, an unnamed lava between the Tram Tuff and Lithic Ridge Tuff, (Carr, 1988 p. 37) (Sawyer and others, 1994, p. 1305) and the Lithic Ridge Tuff.

4. Information for calculating water-level altitude:

Reference point: Top of metal tag on well casing; altitude 1,302.06 m (surveyed by U.S. Geological Survey, 1984).

Measuring point: Top of access tubes, $0.207 \mathrm{~m}$ above reference point, upper interval; $0.235 \mathrm{~m}$ above reference point, lower interval.

Depth correction for borehole deviation from vertical: $0.052 \mathrm{~m}$, based on approximate depth to water of $526 \mathrm{~m}$ (1990 data).

Well USW H-6 upper interval was measured hourly and periodically during 1995 . Hourly measurements were made until September 20, 1995; the day the transducer was removed from the well. During the period of hourly measurements, four calibrations of two transducers were performed. In addition, a calibration was completed on October 04, 1994, to calculate water-level altitudes at the beginning of 1995 . Results of the transducer calibrations are as follows: 


\begin{tabular}{cccccc}
\hline $\begin{array}{c}\text { Transducer serial } \\
\text { number }\end{array}$ & Calibration date & $\begin{array}{c}\text { Slope } \\
\text { (meters/millivolt) }\end{array}$ & $\begin{array}{c}\text { Coefficlent of } \\
\text { determination }\end{array}$ & $\begin{array}{c}\text { Water-level } \\
\text { altitude } \\
\text { (meters) }\end{array}$ & $\begin{array}{c}\text { Method of measuring } \\
\text { water level }\end{array}$ \\
\hline 567094 & $10-04-94$ & 0.089 & 1.00 & 776.16 & Tag with transducer \\
567094 & $02-01-95$ & .089 & 1.00 & 776.10 & Tag with transducer \\
567094 & $06-12-95$ & Failed final & Failed final calibration & 776.07 & Chain \#3 \\
621308 & $06-12-95$ & 0.089 & 1.00 & 776.07 & Chain \#3 \\
621308 & $07-25-95$ & .089 & 1.00 & 776.08 & Chain \#3 \\
621308 & $09-20-95$ & .089 & 1.00 & 776.14 & Chain \#4 \\
\hline
\end{tabular}

No data were collected for well USW H-6, upper interval from June 8 through 11, 1995. The data were lost because of failure of transducer 567094. The defective transducer was replaced on June 12, 1995. There was no data collected from July 21 through 25,1995 . These data were lost because of broken wires in the transducer. The transducer was repaired on July 25, 1995. Partial data were collected on April 4 and 12, 1995, because the DCP was off line these two days for calibration of the lower interval. Partial data were collected on July 20 and 25 , 1995 because of the broken wire in the transducer. Daily mean water-level altitudes were not calculated for April 4, April 12, June 7 through 12, or July 20 through 25, 1995. All other hourly transducer data for 1995 are considered to be valid.

Following the removal of the transducer, well USW H-6 upper interval was measured periodically during the remainder of 1995. Measurements were made with Chains \#3 and \#4 with the following results:

\begin{tabular}{rcc}
\hline Date & $\begin{array}{c}\text { Measured water-level altitude } \\
\text { (meters, above sea level) }\end{array}$ & Method of measuring water level \\
\hline $09-20-95$ & 776.14 & Chain \#4 \\
$12-06-95$ & 776.10 & Chain \#3 \\
\hline
\end{tabular}

Daily mean water-level altitudes of the hourly data for well USW H-6 upper interval ranged from 776.03 to $776.30 \mathrm{~m}$ above sea level in 1995 (fig. 33). Monthly mean water-level altitudes for January through September 1995, are listed in table 20. The mean water-level altitude of the 1995 hourly data was $776.13 \mathrm{~m}$ above sea level. This mean altitude was $0.02 \mathrm{~m}$ higher than the mean altitude of $776.11 \mathrm{~m}$ for 1994 (Graves and others, 1996). 


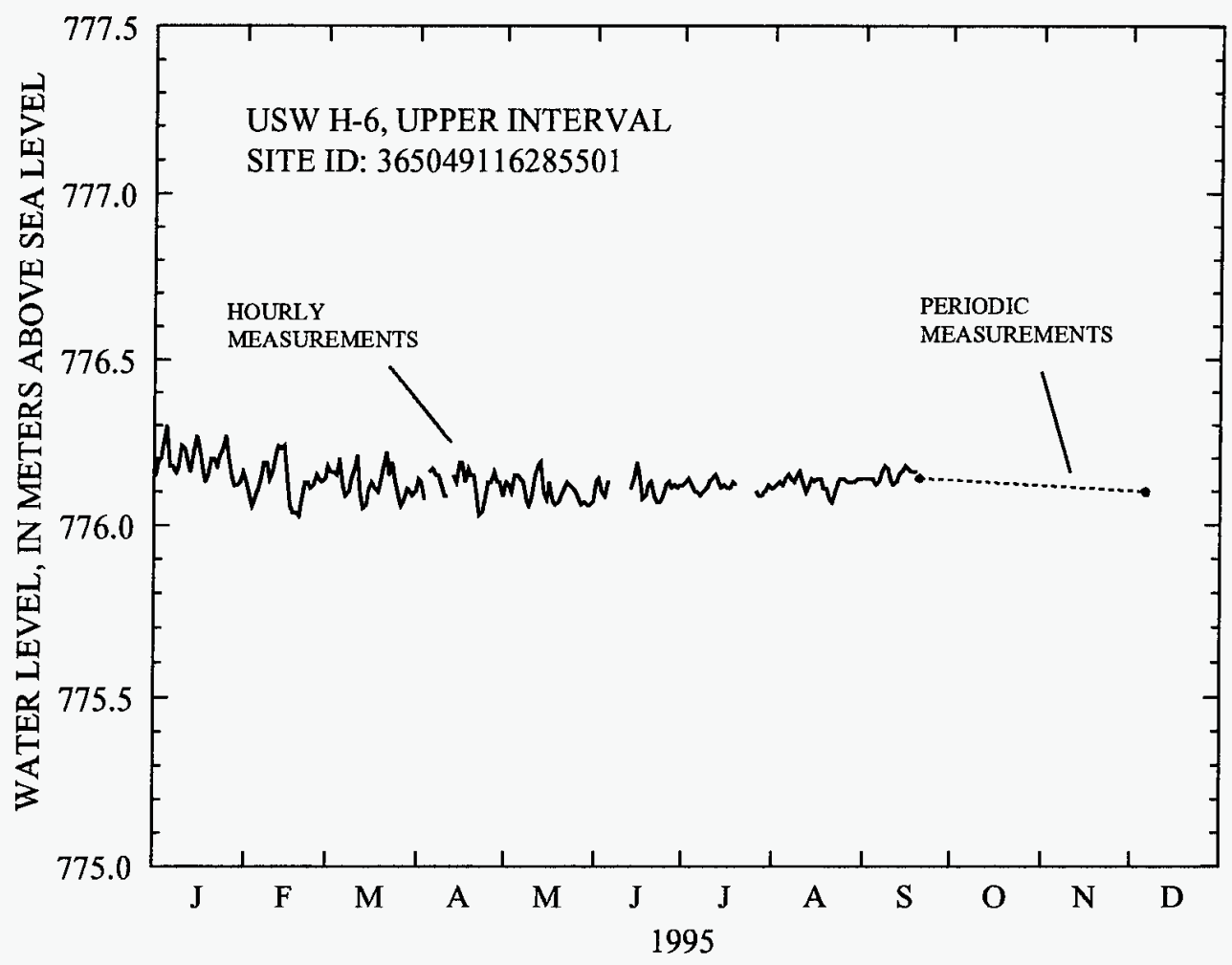

Figure 33. Water-level altitudes, 1995, for well USW H-6, upper interval.

Table 20. Monthly mean water-level altitudes, 1995 , for well USW H-6 upper interval.

[Monthly means were calculated regardless of the number of missing data. Daily means were not calculated if 6 or more consecutive hours of data were missing; --, data not available; NA, not applicable, well not instrumented during this month]

\begin{tabular}{lcc}
\hline Month & $\begin{array}{c}\text { Monthly mean } \\
\text { water-level altitude } \\
\text { (meters, above sea level) }\end{array}$ & $\begin{array}{c}\text { Number of missing daily } \\
\text { means }\end{array}$ \\
\hline January & 776.19 & 0 \\
February & 776.13 & 0 \\
March & 776.13 & 0 \\
April & 776.13 & 2 \\
May & 776.10 & 0 \\
June & 776.11 & 6 \\
July & 776.11 & 6 \\
August & 776.13 & 0 \\
September & 776.15 & 0 \\
October & -- & NA \\
November & -- & NA \\
December & -- & NA \\
\hline
\end{tabular}


Well USW H-6 lower interval was measured hourly and periodically during 1995 . Hourly measurements were made until September 20,1995; the day the transducer was removed from the well. During the period of hourly measurements, five calibrations of two transducers were performed. In addition, a calibration was completed on November 17, 1994, to calculate water-level altitudes at the beginning of 1995 . Results of the transducer calibrations are as follows:

\begin{tabular}{cccccc}
\hline $\begin{array}{c}\text { Transducer serial } \\
\text { number }\end{array}$ & $\begin{array}{c}\text { Calibration } \\
\text { date }\end{array}$ & $\begin{array}{c}\text { Slope } \\
\text { (meters/ } \\
\text { millivolt) }\end{array}$ & $\begin{array}{c}\text { Coefficient of } \\
\text { determination }\end{array}$ & $\begin{array}{c}\text { Water-level } \\
\text { altitude } \\
\text { (meters) }\end{array}$ & $\begin{array}{c}\text { Method of measuring } \\
\text { water level }\end{array}$ \\
\hline 626830 & $11-17-94$ & 0.354 & 1.00 & 776.04 & Chain \#3 \\
\hline 626830 & $02-01-95$ & .353 & 1.00 & 776.04 & Tag with transducer \\
626830 & $04-04-95$ & Failed final & Failed final cali- & 775.97 & Chain \#3 \\
651110 & $04-04-95$ & calibration & bration & & Chain \#3 \\
651110 & $04-12-95$ & .371 & 1.00 & 775.97 & Chain \#3 \\
651110 & $07-25-95$ & .355 & 0.99 & 775.94 & Tag with transducer \\
651110 & $09-20-95$ & .465 & 1.00 & 776.03 & Chain \#4 \\
\hline
\end{tabular}

Transducer 626830 failed its final calibration on April 4, 1995. This transducer was replaced with transducer 651110 . Following the replacement of the transducer, no data were collected for well USW H-6, lower interval from April 4 through 12, 1995, because of a short in a wire in the brass connector of the transducer. Partial data were collected on April 2 and 3, 1995, because of the same short in the wire in the brass connector. The failed transducer was also due to the short in the wire however, this was not known until April 12, 1995. Partial data were collected on July 24 and 25, 1995 because the DCP was off line for the calibration of the upper interval. Daily mean water-level altitudes were not calculated for April 2 through 13, or July 24 and 25, 1995. All other hourly data for 1995 for well USW H-6 lower interval are considered to be valid.

Following the removal of the transducer, well USW H-6 lower interval was measured periodically during the remainder of 1995 . Measurements were made with Chains \#3 and \#4 with the following results:

\begin{tabular}{ccc}
\hline Date & $\begin{array}{c}\text { Measured water-level altitude } \\
\text { (meters, above sea level) }\end{array}$ & Method of measuring water level \\
\hline $09-20-95$ & 775.97 & Chain \#4 \\
$12-06-95$ & 775.98 & Chain \#3 \\
\hline
\end{tabular}

Daily mean water-level altitudes of the hourly data for well USW H-6 lower interval ranged from 775.89 to $776.16 \mathrm{~m}$ above sea level in 1995 (fig. 34). Monthly mean water-level altitudes for January through September 1995, are listed in table 21 . The mean water-level altitude of the 1995 hourly data was $776.01 \mathrm{~m}$ above sea level. This mean altitude was $0.02 \mathrm{~m}$ higher than the mean altitude of $775.99 \mathrm{~m}$ for 1994 (Graves and others, 1996). 


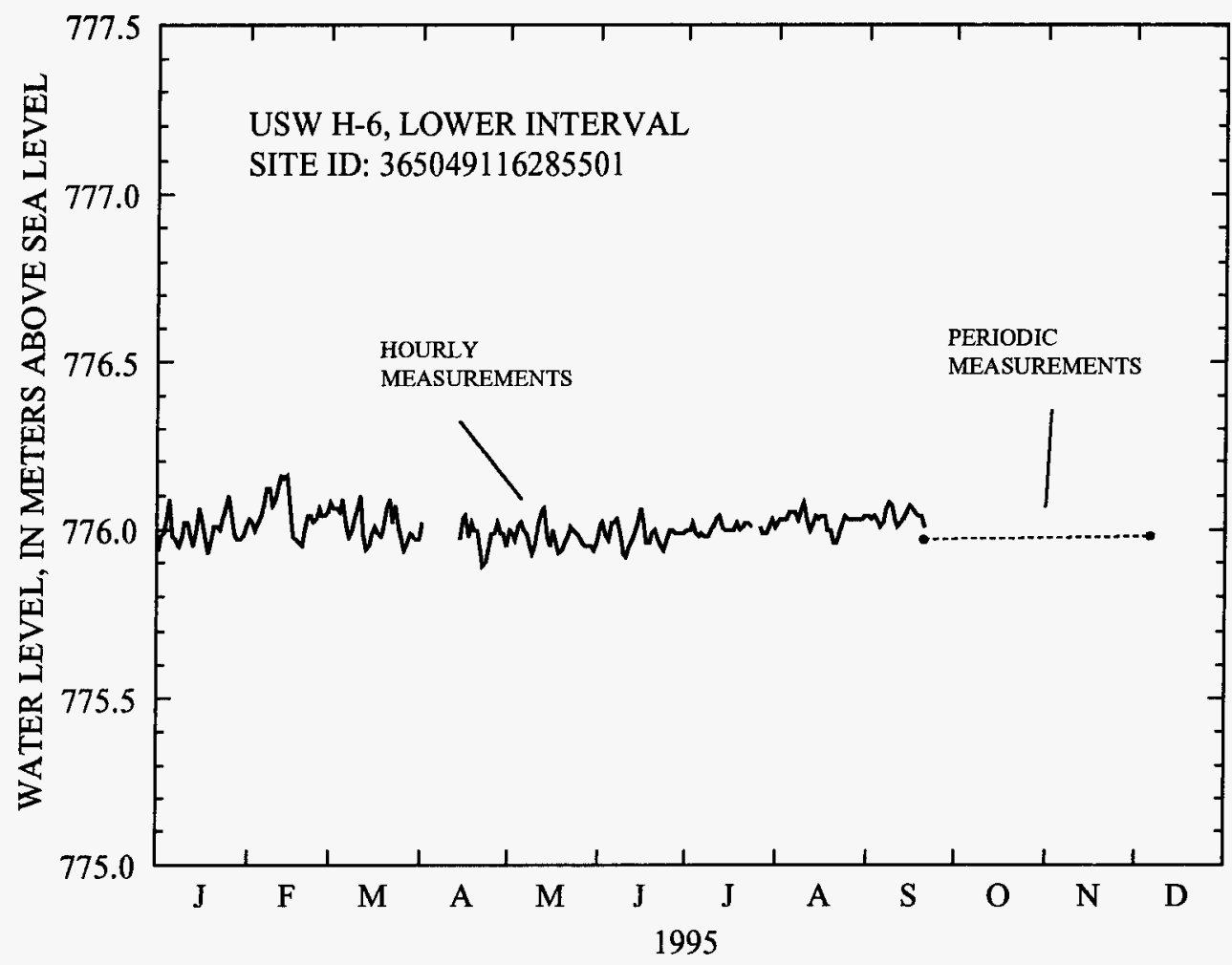

Figure 34. Water-level altitudes, 1995, for well USW H-6, lower interval.

Table 21. Monthly mean water-level altitudes, 1995 , for well USW H-6 lower interval.

[Monthly means were calculated regardless of the number of missing data. Daily means were not calculated if 6 or more consecutive hours of data were missing; --, data not available; NA, not applicable, well not instrumented during this month]

\begin{tabular}{lcc}
\hline Month & $\begin{array}{c}\text { Monthly mean } \\
\text { water-level altitude } \\
\text { (meters, above sea level) }\end{array}$ & $\begin{array}{c}\text { Number of mlssing daily } \\
\text { means }\end{array}$ \\
\hline January & 776.00 & 0 \\
February & 776.05 & 0 \\
March & 776.01 & 0 \\
April & 775.98 & 12 \\
May & 775.98 & 0 \\
June & 775.99 & 0 \\
July & 776.01 & 2 \\
August & 776.03 & 0 \\
September & 776.04 & 0 \\
October & -- & NA \\
November & --- & NA \\
December & -- & NA \\
\hline
\end{tabular}




\section{Well J-11}

Information about the history of well J-11 and about previous data from the well was obtained from Young (1972), and Fenix \& Scisson, Inc. (1987c).

Well specifications

1. Location and identification:

Latitude and longitude: $36^{\circ} 47^{\prime} 06^{\prime \prime} \mathrm{N}$.; $116^{\circ} 17^{\prime} 06^{\prime \prime} \mathrm{W}$.

Nevada State Central Zone Coordinates (m): N 740,968; E 611,764.

U.S. Geological Survey Site ID: 364706116170601.

2. Drilling and casing information:

Well started: June 4, 1957.

Well completed: July 19, 1957.

Drilling method: Cable-tool.

Bit diameter below water level: $400 \mathrm{~mm}$.

Casing extending below water level: $308-\mathrm{mm}$ inside-diameter casing extends from land surface to $404.5 \mathrm{~m}$.

Total drilled depth: $405 \mathrm{~m}$.

3. Access to and description of depth interval for measuring water levels:

308-mm inside-diameter casing; the casing is perforated from 328.3 to $334.4 \mathrm{~m}$ and from 379.2 to $396.2 \mathrm{~m}$. The well produces water from the basalt of Kiwi Mesa and from the welded-tuff aquifer, located within the Topopah Spring Tuff of the Paintbrush Group.

4. Information for calculating water-level altitude:

Reference point: Chiseled " $\mathrm{X}$ " in concrete pad near well; altitude 1,049.45 m (surveyed by U.S. Geological Survey, 1993).

Measuring point: Top of casing, even with top of concrete block, $0.555 \mathrm{~m}$ above reference point.

Depth correction for borehole deviation from vertical is not available.

Well J-11 was measured periodically during 1995 . Measurements were made with Chain \#3, Chain \#4, and the 2,800 foot reference steel tape with the following results:

\begin{tabular}{ccc}
\hline Date & $\begin{array}{c}\text { Measured water-level altitude } \\
\text { (meters, above sea level) }\end{array}$ & $\begin{array}{c}\text { Method of measuring } \\
\text { water lovel }\end{array}$ \\
\hline $01-13-95$ & 732.20 & 2,800 foot reference steel tape \\
$02-10-95$ & 732.26 & Chain \#4 \\
$03-09-95$ & 732.28 & Chain \#3 \\
$04-05-95$ & 732.28 & Chain \#3 \\
$05-08-95$ & 732.23 & Chain \#3 \\
$06-06-95$ & 732.27 & Chain \#3 \\
$07-13-95$ & 732.25 & Chain \#3 \\
$07-24-95$ & 732.25 & Chain \#3 \\
$08-29-95$ & 732.29 & Chain \#3 \\
$09-14-95$ & 732.24 & 2,800 foot reference steel tape \\
$12-04-95$ & 732.24 & Chain \#3 \\
\hline
\end{tabular}


Water-level altitudes for well J-11 ranged from 732.20 to $732.29 \mathrm{~m}$ above sea level in 1995 (fig. 35). The mean water-level altitude of the 1995 periodic data was $732.25 \mathrm{~m}$ above sea level. This mean altitude was $0.04 \mathrm{~m}$ higher than the mean altitude of $732.21 \mathrm{~m}$ for 1994 (Graves and others, 1996).

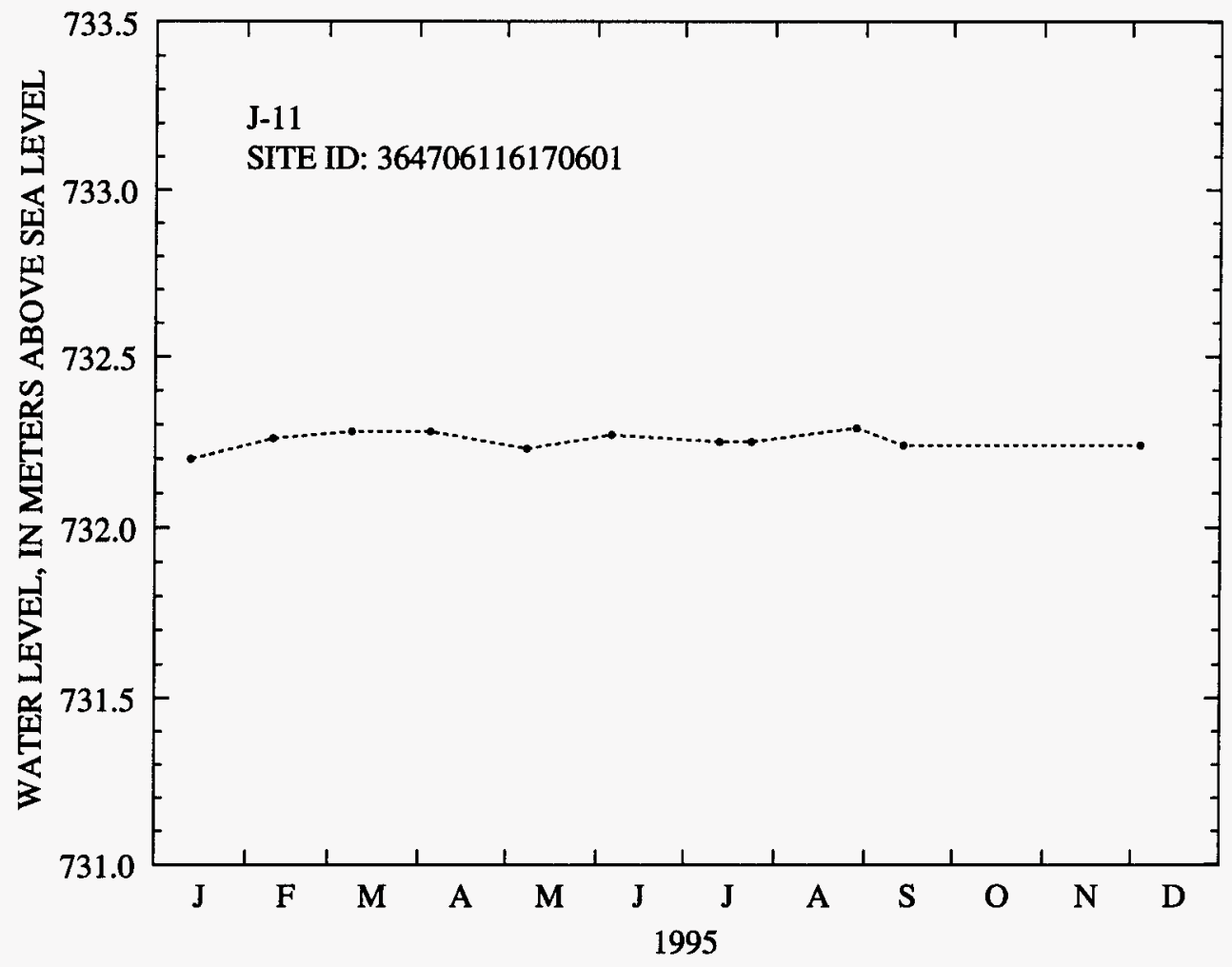

Figure 35. Water-level altitudes, 1995, for well J-11.

\section{Well J-12}

Information about the history of well $\mathrm{J}-12$ and about previous data from the well was obtained from Young (1972), and Fenix \& Scisson, Inc. (1987c).

Well specifications

1. Location and identification:

Latitude and longitude: $36^{\circ} 45^{\prime} 54^{\prime \prime N}$.; $116^{\circ} 23^{\prime} 24^{\prime \prime} \mathrm{W}$.

Nevada State Central Zone Coordinates (m): N 733,508; E 581,012.

U.S. Geological Survey Site ID: 364554116232401.

2. Drilling and casing information:

Well started: August 4, 1957.

Well completed: October 9, 1957; well was deepened in August 1968.

Drilling method: Cable-tool (1957); unknown 1968.

Bit diameter below water level: $400-\mathrm{mm}$ to $271 \mathrm{~m}, 298-\mathrm{mm}$ to $347 \mathrm{~m}$. 
Casing extending below water level: $308-\mathrm{mm}$ inside-diameter casing extending from land surface to $271 \mathrm{~m}$. Total drilled depth: $271 \mathrm{~m}$ (1957); $347 \mathrm{~m}$ after the deepening in 1968.

3. Access to and description of depth interval for measuring water levels:

308 -mm inside-diameter casing; the casing is perforated between $241-264 \mathrm{~m}$; the hole is open from $271 \mathrm{~m}$ to $347 \mathrm{~m}$; access tube is 54-mm outside-diameter. The well produces water from the welded-tuff aquifer, located within the Topopah Spring Tuff of the Paintbrush Group.

4. Information for calculating water-level altitude:

Reference point: Top of well collar, altitude $954.54 \mathrm{~m}$ (surveyed by U.S. Geological Survey, 1993).

Measuring point: Top of the 54-mm outside-diameter access tube, $0.527 \mathrm{~m}$ above reference point through 10-01-95. After 10-01-95 measuring point $0.195 \mathrm{~m}$ above reference point.

Depth correction for borehole deviation from vertical is not available.

5. The amount of water pumped from well $\mathrm{J}-12$ in 1995 was approximately $135,000 \mathrm{~m}^{3}$ (R.A. LaCamera, U.S. Geological Survey, written commun., 1996).

Well J-12 was measured periodically during 1995 . Measurements were made with Chain \#3 and Chain \#4 with the following results:

\begin{tabular}{rcc}
\hline Date & $\begin{array}{c}\text { Measured water-level altitude } \\
\text { (meters, above sea level) }\end{array}$ & $\begin{array}{c}\text { Method of measuring } \\
\text { water level }\end{array}$ \\
\hline $01-12-95$ & 727.88 & Chain \#4 \\
$01-26-95$ & 727.89 & Chain \#4 \\
$02-10-95$ & 727.94 & Chain \#4 \\
$02-24-95$ & 727.88 & Chain \#3 \\
$03-09-95$ & 727.92 & Chain \#3 \\
$03-24-95$ & 727.94 & Chain \#3 \\
$04-05-95$ & 727.93 & Chain \#3 \\
$04-24-95$ & 727.88 & Chain \#3 \\
$05-08-95$ & 727.86 & Chain \#3 \\
$05-18-95$ & 727.84 & Chain \#3 \\
$06-06-95$ & 727.91 & Chain \#3 \\
$06-21-95$ & 727.84 & Chain \#3 \\
$07-10-95$ & 727.87 & Chain \#3 \\
$07-31-95$ & 727.92 & Chain \#3 \\
$08-15-95$ & 727.89 & Chain \#3 \\
$08-30-95$ & 727.94 & Chain \#3 \\
$09-14-95$ & 727.91 & Chain \#4 \\
$12-04-95$ & 727.89 & Chain \#3 \\
\hline
\end{tabular}

Water-level altitudes for well J-12 ranged from 727.84 to $727.94 \mathrm{~m}$ above sea level in 1995 (fig. 36). The mean water-level altitude of the 1995 periodic data was $727.90 \mathrm{~m}$ above sea level. This mean altitude was $0.01 \mathrm{~m}$ lower than the mean altitude of $727.91 \mathrm{~m}$ for 1994 (Graves and others, 1996). 


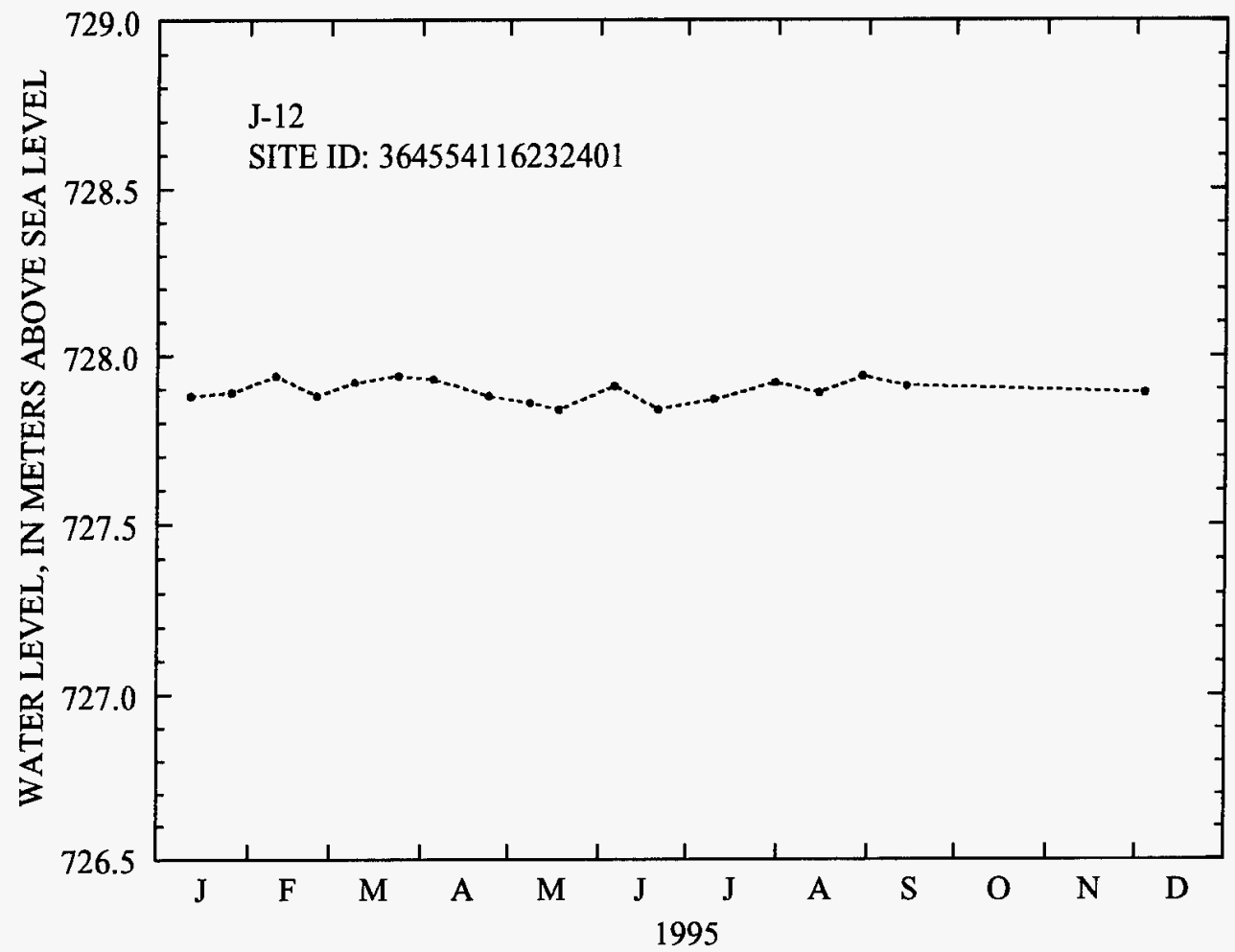

Figure 36. Water-level altitudes, 1995, for well J-12.

\section{Well J-13}

Information about the history of well J-13 and about previous data from the well was obtained from various sources. These sources are: Robison (1984); Robison (U.S. Geological Survey, written commun., 1986); Robison and others (1988); Holmes \& Narver, Inc. (written commun., 1986); Thordarson (1983); Young (1972); and Fenix \& Scisson, Inc. (1987c).

Well specifications

1. Location and identification:

Latitude and longitude: $36^{\circ} 48^{\prime} 29 " \mathrm{~N} . ; 116^{\circ} 23^{\prime} 40^{\prime \prime} \mathrm{W}$.

Nevada State Central Zone Coordinates (m): N 228,359; E 176,678.

U.S. Geological Survey Site ID: 364828116234001.

2. Drilling and casing information:

Well started: September 12, 1962.

Well completed: January 8, 1963.

Drilling method: Rotary, using air and aerated mud as circulating medium.

Bit diameter below water level: $438 \mathrm{~mm}$ to $402 \mathrm{~m} ; 380 \mathrm{~mm}$ from $402 \mathrm{~m}$ to $471 \mathrm{~m}$; $194 \mathrm{~mm}$ from $471 \mathrm{~m}$ to total depth. 
Casing extending below water level: $323-\mathrm{mm}$ inside diameter, from land surface to $396.5 \mathrm{~m}$; $282-\mathrm{mm}$ inside diameter from 396.5 to $471.2 \mathrm{~m}$; 126 -mm inside diameter from 452.3 to $1,031.7 \mathrm{~m}$; casing perforated from 303.6 to $423.7 \mathrm{~m}$ is within the Topopah Spring Tuff of the Paintbrush Group, and from 819.9 to $1,009.5 \mathrm{~m}$ is within the Tram Tuff of the Crater Flat Group and upper part of the Lithic Ridge Tuff.

Total drilled depth: $1,063 \mathrm{~m}$.

3. Access to and description of depth interval for measuring water levels:

50.8-mm inside-diameter access tube, installed in 1986, in order for measuring equipment to bypass pump assembly.

4. Information for calculating water-level altitude:

Reference point: Chiseled square on concrete well collar, altitude $1,011.47 \mathrm{~m}$ above reference point (surveyed by U.S. Geological Survey, 1984).

Measuring point: Top of access tube, $0.165 \mathrm{~m}$.

Depth correction for borehole deviation from vertical is not available.

5. The amount of water pumped from well $\mathrm{J}-13$ in 1995 was approximately $184,600 \mathrm{~m}^{3}$ (R.A. LaCamera, U.S. Geological Survey, written commun., 1996).

Well J-13 was measured periodically during 1995 . Measurements were made with Chain \#3 and Chain \#4 with the following results:

\begin{tabular}{rcc}
\hline Date & $\begin{array}{c}\text { Measured water-level altitude } \\
\text { (meters, above sea level) }\end{array}$ & $\begin{array}{c}\text { Method of measuring } \\
\text { water level }\end{array}$ \\
\hline $01-12-95$ & 728.41 & Chain \#4 \\
$01-26-95$ & 728.42 & Chain \#4 \\
$02-10-95$ & 728.48 & Chain \#4 \\
$02-24-95$ & 728.38 & Chain \#3 \\
$03-09-95$ & 728.43 & Chain \#3 \\
$03-24-95$ & 728.44 & Chain \#3 \\
$04-05-95$ & 728.46 & Chain \#3 \\
$04-24-95$ & 728.40 & Chain \#3 \\
$05-08-95$ & 728.39 & Chain \#3 \\
$05-18-95$ & 728.59 & Chain \#3 \\
$06-06-95$ & 728.59 & Chain \#3 \\
$06-29-95$ & 728.43 & Chain \#3 \\
$07-12-95$ & 728.39 & Chain \#3 \\
$07-31-95$ & 728.36 & Chain \#3 \\
$08-15-95$ & 728.34 & Chain \#3 \\
$12-12-95$ & 728.43 & Chain \#3 \\
\hline
\end{tabular}

Water-level altitudes from the hourly data for well J-13 ranged from 728.34 to $728.59 \mathrm{~m}$ above sea level in 1995 (fig. 37). The mean water-level altitude of the 1995 periodic data was $728.43 \mathrm{~m}$ above sea level. This mean altitude was $0.03 \mathrm{~m}$ was higher than the mean altitude of $728.40 \mathrm{~m}$ for 1994 (Graves and others, 1996). 


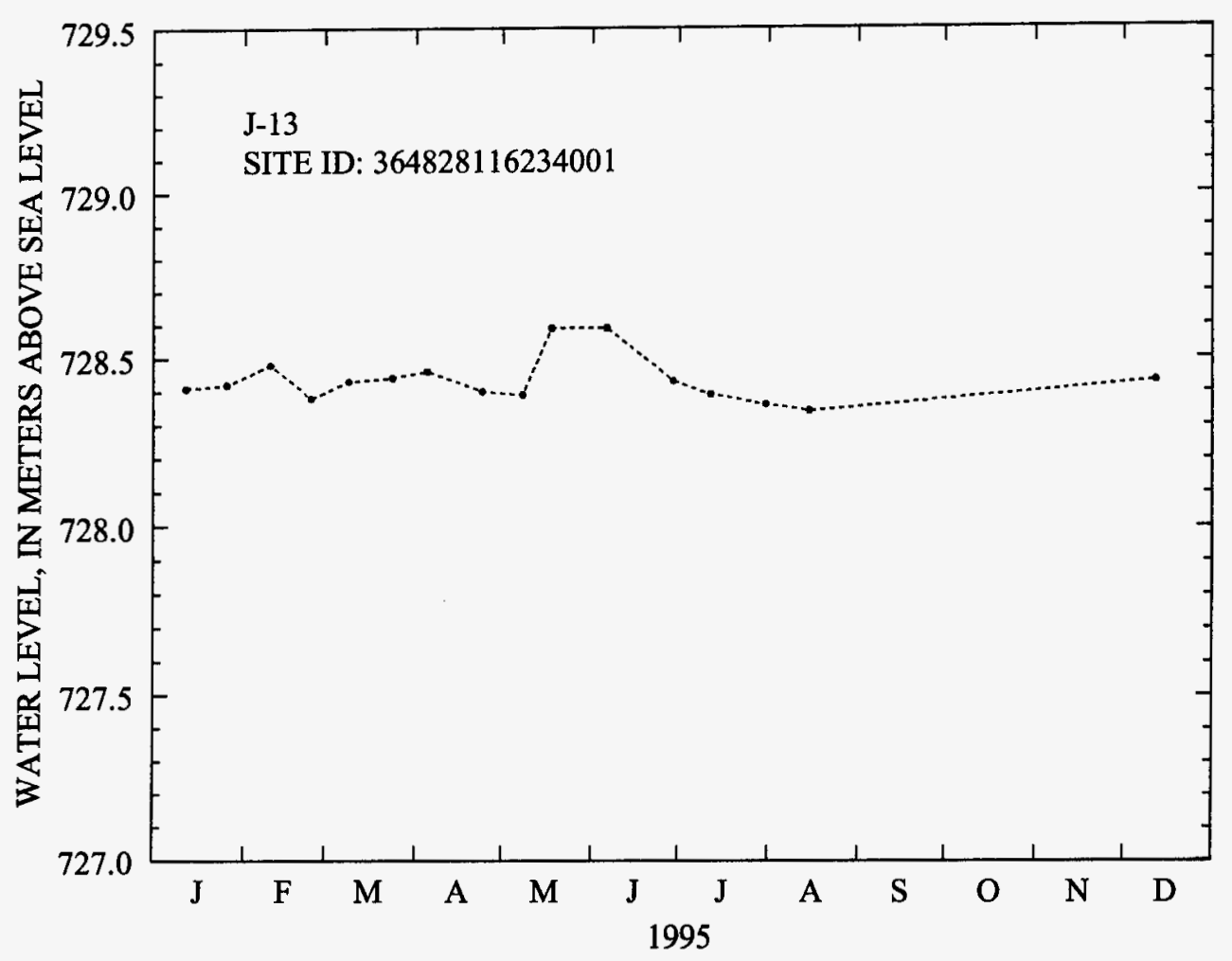

Figure 37. Water-level altitudes, 1995, for well J-13.

\section{REFERENCES CITED}

Bentley, C.B., Robison, J.H., and Spengler, R.W., 1983, Geohydrologic data for test well USW H-5, Yucca Mountain area, Nye County, Nevada: U.S. Geological Survey Open-File Report 83-853, 34 p.

Blee, J.W.H., Herlong, H.E., Kauffman, C.D., Jr., Hardee, J.H., Field, M.L., and Middelburg, R.F., Jr., 1986, GOES datacollection system instrumentation, installation, and maintenance manual: U.S. Geological Survey Open-File Report 86-479, various pagination.

Boucher, M.S., 1994a, Precision and accuracy of manual water-level measurements taken in the Yucca Mountain area, Nye County, Nevada, 1988-90: U.S. Geological Survey Water-Resources Investigations Report 93-4025, 18 p.

Boucher, M.S., 1994b, Water levels in wells J-11 and J-12, 1989-91, Yucca Mountain area, Nevada: U.S. Geological Survey Open-File Report 94-303, 9 p.

Byers, F.M., Jr., Carr, W.J., Orkild, P.P., Quinlivan, W.D., and Sargent, K.A., 1976, Volcanic suites and related cauldrons of Timber Mountain—Oasis Valley caldera complex, southern Nevada: U.S. Geological Survey Professional Paper 919, $70 \mathrm{p}$.

Carr, W.J., Byers, F.M., Jr., and Orkild, P.P., 1986, Stratigraphic and volcano-tectonic relations of Crater Flat Tuff and some older volcanic units, Nye County, Nevada: U.S. Geological Survey Professional Paper 1323, 28 p.

Carr, W.J., 1988, Volcano-tectonic setting of Yucca Mountain and Crater Flat, southwestern Nevada, in Carr, M.D., and Yount, J.C. (eds.), Geologic and hydrologic investigations of a potential nuclear waste disposal site at Yucca Mountain, southern Nevada: U.S. Geological Survey Bulletin 1790, p. 35-49.

Craig, R.W., and Johnson, K.A., 1984, Geohydrologic data for test well UE-25 p\#1, Yucca Mountain area, Nye County, Nevada: U.S. Geological Survey Open-File Report 84-450, 63 p.

Craig, R.W., Reed, R.L., and Spengler, R.W., 1983, Geohydrologic data for test well USW H-6, Yucca Mountain area, Nye County, Nevada: U.S. Geological Survey Open-File Report 83-856, 35 p. 
Craig, R.W., and Robison, J.H., 1984, Geohydrology of test well UE-25 p\#1, Yucca Mountain area, Nye County, Nevada: U.S. Geological Survey Water-Resources Investigations Report 84-4248, 57 p.

Erickson, J.R., and Waddell, R.K., 1985, Identification and characterization of hydrologic properties of fractured tuff using hydraulic and tracer tests - test well USW H-4, Yucca Mountain, Nye County, Nevada: U.S. Geological Survey WaterResources Investigations Report 85-4066, $30 \mathrm{p}$.

Fenix \& Scisson, Inc., 1986a, NNWSI hole histories-UE-25 WT\#3, UE-25 WT\#4, UE-25 WT\#5, UE-25 WT\#6, UE-25 WT\#12, UE-25 WT\#13, UE-25 WT\#14, UE-25 WT\#15, UE-25 WT\#16, UE-25 WT\#17, UE-25 WT\#18, USW WT-1, USW WT-2, USW WT-7, USW WT-10, USW WT-11: U.S. Department of Energy DOE/NV/10322-10, 111 p. 1986b, NNWSI hole history-UE-25 b\#1: U.S. Department of Energy DOE/NV/10322-13, 37 p. 1986c, NNWSI hole history-UE-25 p\#1: U.S. Department of Energy DOE/NV/10322-16, 39 p. 1987a, NNWSI hole histories - USW H-1, USW H-3, USW H-4, USW H-5, USW H-6: U.S. Department of Energy DOE/NV/10322-18, $99 \mathrm{p}$. 1987b, NNWSI hole histories_USW G-1, USW G-2, USW G-3, USW G-4, USW GA-1, USW GU-3: U.S. Department of Energy DOE/NV/10322-19, $187 \mathrm{p}$. 1987c, NNWSI drilling and mining summary: U.S. Department of Energy DOE/NV/10322-24, 45 p.

Garber, M.S., and Koopman, F.C., 1968, Methods of measuring water levels in deep wells: U.S. Geological Survey Techniques of Water-Resources Investigations, book 8, chap. A-1, 23 p.

Gemmell, J.M., 1990, Water levels in periodically measured wells in the Yucca Mountain area, Nevada, 1988:

U.S. Geological Survey Open-File Report 90-113, 47 p.

Graves, R.P., Tucci, Patrick, and Goemaat, R.L., 1996, Water levels in the Yucca Mountain area, Nevada, 1994: U.S. Geological Survey Open-File Report 95-757, 101 p.

Lahoud, R.G., Lobmeyer, D.H., and Whitfield, M.S., Jr., 1984, Geohydrology of volcanic tuff penetrated by test well UE-25 b\#1, Yucca Mountain, Nye County, Nevada: U.S. Geological Survey Water-Resources Investigations Report 84-4253, $44 \mathrm{p}$.

Lobmeyer, D.H., Whitfield, M.S., Jr., Lahoud, R.G., and Bruckheimer, Laura, 1983, Geohydrologic data for test well UE-25 b\#1, Nevada Test Site, Nye County, Nevada: U.S. Geological Survey Open-File Report 83-855, 48 p.

Lobmeyer, D.H., Luckey, R.R., O'Brien, G.M., and Burkhardt, D.J., 1995, Water levels in continuously monitored wells in the Yucca Mountain area, Nevada, 1989, U.S. Geological Survey Open-File Report 93-098, 173 p.

Luckey, R.R., Lobmeyer, D.H., and Burkhardt, Douglas, 1993, Water levels in continuously monitored wells in the Yucca Mountain area, Nevada, 1985-88: U.S. Geological Survey Open-File Report 91-493, 252 p.

Maldonado, Florian, and Koether, S.L., 1983, Stratigraphy, structure, and some petrographic features of Tertiary volcanic rocks at the USW G-2 Drill Hole, Yucca Mountain, Nye County, Nevada: U.S. Geological Survey Open-File Report $83-732,83 \mathrm{p}$.

Muller, D.C., and Kibler, J.E., 1985, Preliminary analysis of geophysical logs from WT series drill holes, Yucca Mountain, Nye County, Nevada: U.S. Geological Survey Open-File Report 86-46, 29 p.

Nelson, P.H., Muller, D.C., Schimschal, Ulrich, and Kibler, J.E., 1991, Geophysical logs and core measurements from forty boreholes at Yucca Mountain, Nevada: U.S. Geological Survey Geophysical Investigations Map GP-1001, 64 p., 40 pls.

Nelson, P.H., and Schimschal, Ulrich, 1993, Assessment of geophysical logs from borehole USW G-2, Yucca Mountain, Nevada: U.S. Geological Survey Open-File Report 92-572, 34 p.

O'Brien, G.M., 1991, Water levels in periodically measured wells in the Yucca Mountain area, Nevada, 1989: U.S. Geological Survey Open-File Report 91-178, 51 p. 1992, Earthquake-induced water-level fluctuations at Yucca Mountain, Nevada, April, 1992: U.S. Geological Survey Open-File Report 92-137, 10 p. 1993, Earthquake-induced water-level fluctuations at Yucca Mountain, Nevada, June, 1992: U.S. Geological Survey Open-File Report 93-73, 12 p.

O'Brien, G.M., Tucci, Patrick, and Burkhardt, D.J., 1995, Water levels in the Yucca Mountain area, Nevada, 1992: U.S. Geological Survey Open-File Report 94-311, 74 p.

O'Brien, G.M., 1997, Analysis of aquifer tests conducted in boreholes USW WT-10, UE-25 WT\#12, and USW SD-7, 199596, Yucca Mountain, Nevada: U.S. Geological Survey Water-Resources Investigations Report 96-4293, 36 p.

Robison, J.H., 1984, Ground-water level data and preliminary potentiometric surface maps, Yucca Mountain and vicinity, Nye County, Nevada: U.S. Geological Survey Water-Resources Investigations Report 84-4197, 8 p.

Robison, J.H., Stephens, D.M., Luckey, R.R., and Baldwin, D.A., 1988, Water levels in periodically measured wells in the Yucca Mountain area, Nevada, 1981-87: U.S. Geological Survey Open-File Report 88-468, 132 p. 
Rush, F.E., Thordarson, William, and Bruckheimer, Laura, 1983, Geohydrologic and drill-hole data for test well USW H-1, adjacent to Nevada Test Site, Nye County, Nevada: U.S. Geological Survey Open-File Report 83-141, 38 p.

Rush, F.E., Thordarson, William, and Pyles, D.G., 1984, Geohydrology of test well USW H-1, Yucca Mountain, Nye County, Nevada: U.S. Geological Survey Water-Resources Investigations Report 84-4032, 56 p.

Sass, J.H., and Lachenbruch, A.H., 1982, Preliminary interpretation of thermal data from the Nevada Test Site: U.S. Geological Survey Open-File Report 82-973, 30 p.

Sawyer, D.A., Fleck, R.J., Lanphere, M.A., Warren, R.G., Broxton, M.R., 1994, Episodic caldera volcanism in the Miocene southwestern Nevada volcanic field: Revised stratigraphic framework, ${ }^{40} \mathrm{Ar} /{ }^{39} \mathrm{Ar}$ geochronology, and implications for magmatism and extension: Geological Society of America Bulletin, v. 106, p. 1304-1418.

Thordarson, William, 1983, Geohydrologic data and test results from well J-13, Nevada Test Site, Nye County, Nevada: U.S. Geological Survey Water-Resources Investigations Report 83-4171, $57 \mathrm{p}$.

Thordarson, William, and Howells, Lewis, 1987, Hydraulic tests and chemical quality of water at well USW VH-1, Crater Flat, Nye County, Nevada: U.S. Geological Survey Water-Resources Investigations Report 86-4359, 20 p.

Thordarson, William, Rush, F.E., Spengler, R.W., and Waddell, S.J., 1984, Geohydrologic and drill-hole data for test well USW H-3, Yucca Mountain, Nye County, Nevada: U.S. Geological Survey Open-File Report 84-149, 54 p.

Thordarson, William, Rush, F.E., and Waddell, S.J., 1984, Geohydrology of test well USW H-3, Yucca Mountain, Nye County, Nevada: U.S. Geological Survey Water-Resources Investigations Report 84-4272, 38 p.

Tucci, Patrick, O'Brien, G.M., and Burkhardt, D.J., 1996, Water levels in the Yucca Mountain area, Nevada, 1990-91: U.S. Geological Survey Open-File Report 94-111, 107 p.

Tucci, Patrick, Goemaat R.L., and Burkhardt, D.J., 1996, Water levels in the Yucca Mountain area, Nevada, 1993: U.S. Geological Survey Open-File Report 95-159, 94 p.

U.S. Department of Energy, 1988, Site characterization plan, Yucca Mountain site, Nevada research and development area, Nevada: U.S. Department of Energy Report DOE RW/0199, 8 v., various pagination.

Whitfield, M.S., Jr., Eshom, E.P., Thordarson, William, and Schaefer, D.H., 1985, Geohydrology of rocks penetrated by test well USW H-4, Yucca Mountain, Nye County, Nevada: U.S. Geological Survey Water-Resources Investigations Report $85-4030,33 \mathrm{p}$.

Whitfield, M.S., Jr., Thordarson, William, and Eshom, E.P., 1984, Geohydrologic and drill-hole data for test well USW H-4, Yucca Mountain, Nye County, Nevada: U.S. Geological Survey Open-File Report 84-449, 39 p.

Winograd, I.J., and Thordarson, William, 1975, Hydrogeologic and hydrochemical framework, south-central Great Basin, Nevada-California, with special reference to the Nevada Test Site: U.S. Geological Survey Professional Paper 712-C, $126 \mathrm{p}$.

Young, R.A., 1972, Water supply for the Nuclear Rocket Development Station at the U.S. Atomic Energy Commission's Nevada Test Site: U.S. Geological Survey Water-Supply Paper 1938, 19 p. 
M98004914

|||||||||||||||

Report Number (14) le S69\% $/ 0$ FR $-97-101$

Publ. Date (11) 1998

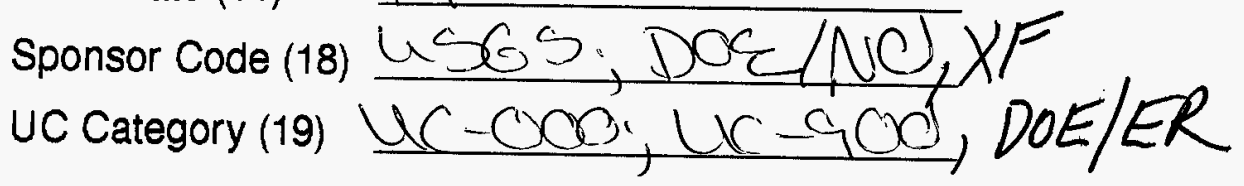

DOE 